\title{
Modulação do processo de cicatrização pelos ácidos oleico e linoleico
}

Tese apresentada ao Programa de PósGraduação em Fisiologia Humana do Instituto de Ciências Biomédicas da Universidade de São Paulo, para a obtenção do título de Doutor em Ciências.

São Paulo 


\section{Hosana Gomes Rodrigues}

\section{Modulação do processo de cicatrização pelos ácidos oleico \\ e linoleico}

Tese apresentada ao Programa de PósGraduação em Fisiologia Humana do Instituto de Ciências Biomédicas da Universidade de São Paulo, para a obtenção do título de Doutor em Ciências.

Área de concentração: Fisiologia Humana Orientador: Prof. Dr. Rui Curi

Versão Original

São Paulo 
DADOS DE CATALOGAÇÃO NA PUBLICAÇÃO (CIP)

Serviço de Biblioteca e Informação Biomédica do

Instituto de Ciências Biomédicas da Universidade de São Paulo

reprodução não autorizada pelo autor

Rodrigues, Hosana Gomes.

Modulação do processo de cicatrização pelos ácidos oleico e linoleico / Hosana Gomes Rodrigues. -- São Paulo, 2011.

Orientador: Rui Curi.

Tese (Doutorado) - Universidade de São Paulo. Instituto de Ciências Biomédicas. Departamento de Fisiologia e Biofísica. Area de concentração: Fisiologia Humana. Linha de pesquisa: Efeitos de ácidos graxos em leucócitos.

Versão do título para o inglês: Modulation of the wound healing by oleic and linoleic acids

Descritores: 1. Ácidos graxos 2. Cicatrização 3. Ácido oleico 4. Ácido linoleico 5. Citocinas 6. Inflamação I. Curi, Rui II. Universidade de São Paulo. Instituto de Ciências Biomédicas. Programa de PósGraduação em Fisiologia Humana III. Título. 
Candidato(a): Hosana Gomes Rodrigues.

Título da Tese: $\quad$ Modulação do processo de cicatrização pelos ácidos oleico e linoleico.

Orientador(a): $\quad$ Rui Curi.

A Comissão Julgadora dos trabalhos de Defesa da Tese de Doutorado, em sessão pública realizada a ...................................., considerou

\section{( ) Aprovado(a) ( ) Reprovado(a)}

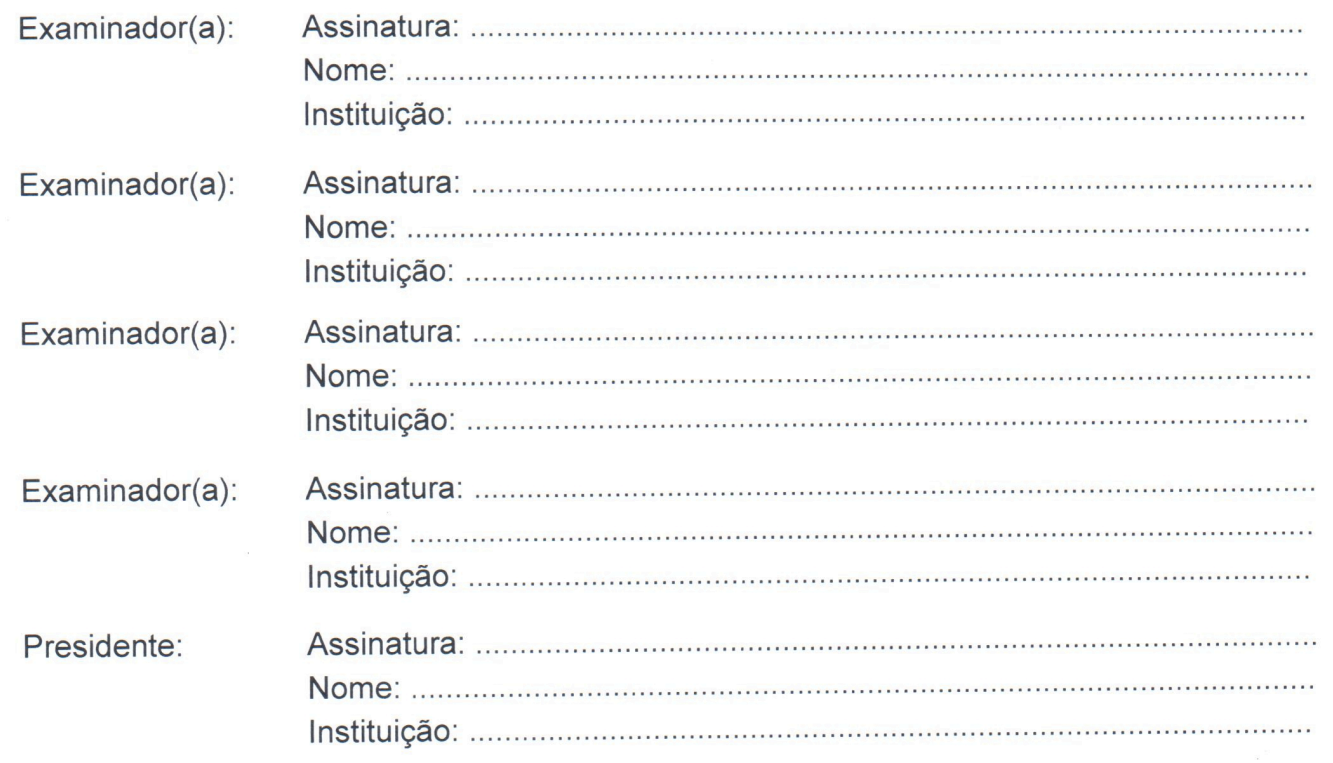




\section{Certificado}

Certificamos que o protocolo registrado sob $n^{\circ} 86$ nas fls. 48 do livro 2 para uso de animais em experimentação, sob a responsabilidade de Rui Cusi Coordenador(a) da Linha de pesquisa "Moctulaçâo do processo de cicartricacâo pelos ácidos oléico e linoleico em natbos submetidos a diabetes meltitus" do qual participou(aram) o(s) alunos Fosana Gomes Rodrigues, Mullana Magalaton e a pesquisadora Iflaine Batanalea, está de acordo com os Principios Éticos de Experimentaçāo Animal adotado pelo Colégio Brasileiro de Experimentaçāo Animal (COBEA) e foi aprovado pela COMISSÃO DE ÉTICA EM EXPERIMENTAÇĀO ANIMAL (CEEA) em 31.08.2007.

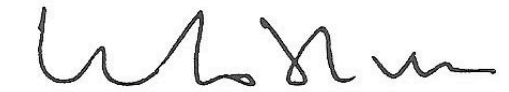

Prof. Dr. WOTHAN TAVARES DE LIMA Coordenador CEEA - ICB/USP
São Paulo, 03 de setembro de 2007.

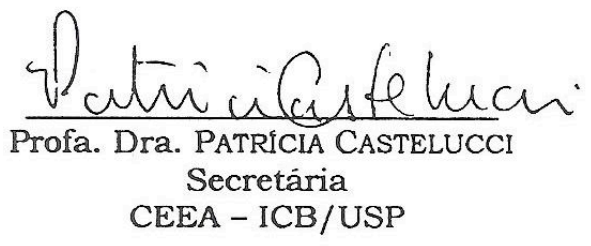




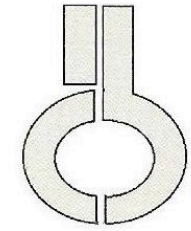

UNIVERSIDADE DE SÃO PAULO INSTITUTO DE CIÊNCIAS BIOMÉDICAS

Cidade Universitária "Armando de Salles Oliveira"

Av. Prof. Lineu Prestes, 2415 - cep. 05508-000 São Paulo, SP - Brasil

Telefone :(55) (011) 3091.7733 - telefax : (55) (011) 30917438

e-mail: cep@icb.usp.br

Of.CEUA.51.10

WTL/mcgn

São Paulo, 03 de agosto de 2010.

REF.: Protocolo n'086/07.

"Modulação do processo de cicatrização pelos ácidos oléico e linoleico em ratos submetidos ao diabetes mellitus"

Prezado Professor,

Informo que a sua licença para uso de animais em experimentação, constante no protocolo em epígrafe, foi prorrogada até 31.08.2013.

Reitero que havendo alteração de metodologia e inserção de novos alunos ao projeto de pesquisa vinculado à referida licença a CEUAICB deverá ser informada.

Cordialmente,

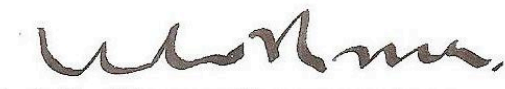

Prof. Dr. WOTHAN TAVARES DE LIMA

Coordenador da Comissão de Ética no Uso de Animal - ICB /USP

Ilmo.Sr.

Prof Dr. RUICURI

Departamento de Fisiologia e Biofisica

Instituto de Ciências Biomédicas - USP 
Aos meus pais,
Maria Auxiliadora Rodrigues e Wellynton Gomes Rodrigues (in memoriam) pelo amor, dedicação e eterno incentivo. 
A minha irmã Fernanda, por não me deixar desistir deste sonho.

Aos meus irmãos Alexandre e Raquel pelo apoio emocional, estímulo e carinho.

Aos meus familiares e amigos por toda a atenção dispensada.

Ao Prof. Rui Curi por tornar esse sonho realidade. E pela oportunidade de conviver com esse ser humano incrível.

Aos amigos do laboratório pelos experimentos, discussões, risadas, churrascos, por terem feito desse período uma fase muito mais divertida.

Aos técnicos do laboratório e do ICB por tornarem meu trabalho possível.

Aos integrantes dos laboratórios da Prof. Dr. Marinilce Fagundes dos Santos, Prof. Dr. Patrícia Gama e Prof. Sandra Farsky pelas colaborações e amizades.

A FAPESP pelo apoio financeiro, sem o qual seria inviável a realização deste estudo. 


\section{RESUMO}

RODRIGUES, HG. Modulação do processo de cicatrização pelos ácidos oleico e linoleico. $200190 \mathrm{f}$. Tese (Doutorado em Fisiologia Humana) - Instituto de Ciências Biomédicas, Universidade de São Paulo, São Paulo, 2011.

No Brasil, misturas de ácidos graxos (AGs) contendo os ácidos oleico (OL monoinsaturado) e linoleico ( $\mathrm{Li}$ - poliinsaturado) são utilizadas topicamente no tratamento das úlceras de pressão. Entretanto, o mecanismo de ação desses na cicatrização é pouco conhecido. O presente estudo teve como objetivo caracterizar o processo de cicatrização e investigar os efeitos da suplementação nutricional (gavagem) com OL e Li em estudos in vivo e ex vivo. Após anestesia, uma área de10 $\mathrm{mm}^{2}$ de pele foi removida cirurgicamente da região dorsal dos animais. A suplementação com OL e Li não alterou os parâmetros nutricionais. As atividades séricas das enzimas marcadoras de danos hepáticos (AST, ALT e LDH) e a análise histológica do intestino delgado não evidenciaram qualquer efeito tóxico do procedimento experimental. A suplementação com Li reduziu o tamanho das feridas no sétimo dia após a indução. Esse resultado foi acompanhado de aumento na produção de peróxido de hidrogênio $\left(\mathrm{H}_{2} \mathrm{O}_{2}\right)$. Apesar de não ter elevado a produção de $\mathrm{H}_{2} \mathrm{O}_{2}$ na primeira hora, o OL reduziu o conteúdo deste após 24 horas. $\mathrm{A}$ administração de Li acelerou a resposta migratória, aparecendo células inflamatórias uma hora após o ferimento. A ingestão de $\mathrm{OL}$ induziu ativação do fator de transcrição NF-KB e o Li ativou AP-1 após uma hora. Em 24 horas, ambos AGs reduziram a ativação do NF-kB e não alteraram o estado de ativação do AP-1. Li elevou as concentrações de CINC-2 $\alpha \beta$ e OL aumentou TNF- $\alpha$, no homogenato, uma hora após a indução da ferida. Em 24 horas, ambos AGs reduziram a expressão e as concentrações de IL-1 $\beta$, IL- 6 e MIP-3 $\alpha$. Não foram observadas modificações nas concentrações de VEGF nos grupos estudados. A suplementação com $\mathrm{OL}$ e $\mathrm{Li}$ acelerou a fase inflamatória do processo de cicatrização. Os efeitos da suplementação com OL e Li sobre funções de neutrófilos foram então estudados. A resposta migratória dos neutrófilos foi aumentada após a ingestão de OL e Li. O mesmo ocorreu com a expressão de L-selectina. Observamos também aumento no rolamento e na aderência dos leucócitos aos vasos. A produção de citocinas próinflamatórias (CINC-2 $\alpha \beta$ e IL-1 $\beta$ ) foi modificada pela ingestão de OL e Li; aumento em 4 horas (Li) e redução ( $\mathrm{OL}$ e Li) em 18 horas de incubação. Desta forma, a 
suplementação com OL e Li acelera o processo de cicatrização e os neutrófilos estão envolvidos

Palavras-chave: Ácidos graxos. Cicatrização. Suplementação. Citocinas. Inflamação. 


\section{ABSTRACT}

RODRIGUES, HG. Modulation of the wound healing by oleci and linoleic acids supplementation. 201190 f. Ph.D. Thesis (Human Physiology) - Instituto de Ciências Biomédicas, Universidade de São Paulo, São Paulo, 2011.

In Brazil, fatty acids (FA) mixtures containing oleic (OL - monounsaturated) and linoleic ( $\mathrm{Li}$ - polyunsaturated) have been topically used in the treatment of pressure ulcers. However, the mechanism involved in the healing process is unknown. This study aimed to characterize the healing process and to investigate the effects of nutritional supplementation (gavage) with $\mathrm{OL}$ and $\mathrm{Li}$ on the healing process through in vivo and in vitro experiments. After anesthesia, an area of $10 \mathrm{~mm}^{2}$ of skin was surgically removed from the dorsum. Supplementation with OL or Li did not alter the nutritional parameters. Serum activities of marker enzymes of liver damage (AST, ALT and LDH) and histology of the small intestine of the rats supplemented with the fatty acids did not show any toxicity sign. Li supplementation reduced the size of the wounds on the seventh day after induction. This result was accompanied by increased production of hydrogen peroxide $\left(\mathrm{H}_{2} \mathrm{O}_{2}\right)$ in the $\mathrm{Li}$ group. OL reduced the $\mathrm{H}_{2} \mathrm{O}_{2}$ content after 24 hours and had no effect after one hour. Li administration accelerated the migratory response, since inflammatory cells were found one hour after the wound. The intake of OL activated the transcription factor NF-KB and $\mathrm{Li}$ increased the activation of AP-1 one hour after induction of the wound. Both fatty acids reduced the activation of NF-KB and did not alter the state of activation of AP-1 after 24 hours. Li raised the concentrations of CINC-2 $\alpha \beta$ and OL increased TNF- $\alpha$, in the homogenate, one hour after wound induction. In 24 hours, the FA reduced expression and concentrations of IL-1 $\beta, I L-6$ and MIP-3 $\alpha$. There were no changes in the concentrations of VEGF in any group. Putting together, our results demonstrate that $\mathrm{OL}$ and $\mathrm{Li}$ accelerate the inflammatory phase of the wound healing. The effects of supplementation with $\mathrm{OL}$ and $\mathrm{Li}$ on neutrophil functions were then investigated. The migratory response of neutrophils was increased after ingestion of $\mathrm{OL}$ and $\mathrm{Li}$. The same occurred with the expression of L-selectin. We also observed an increase in rolling and adherence of leukocytes to vessels. The production of pro-inflammatory cytokines (CINC-and IL-1 $2 \alpha \beta$ ) was modified by OL and Li; increase in 4 hours (Li) and reduction (OL e $\mathrm{Li}$ ) in 18 hours of incubation. Thus, the supplementation with OL or Li accelerates the healing process and neutrophils were involved. 
Key words: Fatty acids. Wound healing. Supplementation. Cytokines. Inflammation. 


\section{LISTA DE ILUSTRAÇÕES}

Figura 1. Fluxograma dos ensaios propostos no projeto. 27

Figura 2. Atividade das enzimas séricas aspartato transaminase (AST), alanina transaminase (ALT) e lactato desidrogenase (LDH) em animais controle $(C)$ e suplementados com os ácidos oléico (OL) ou linoléico (Li) (dose $0,44 \mathrm{~g} / \mathrm{kg}$ de peso corporal) durante 10 dias. 40

Figura 3. Fotomicrografias do intestino delgado de animais controle (C) e suplementados com os ácidos graxos oléico (OL) ou linoléico ( $\mathrm{Li}$ ) (dose de 0,44 $\mathrm{g} / \mathrm{kg}$ de peso corporal) durante 10 dias. Hematoxilina e eosina. 10X. 41

Figura 4. Fechamento da ferida de ratos controle (C) ou suplementados com os ácidos oleico $(\mathrm{OL})$ ou linoleico (Li). Fotos representativas de pelo menos 10 animais por grupo.

Figura 5. Conteúdo de peróxido de hidrogênio $\left(\mathrm{H}_{2} \mathrm{O}_{2}\right)$ no homogenato de feridas retiradas em diferentes períodos de tempo ( 1 e 24 horas) de animais controle (C) ou suplementados com os ácidos oleico (OL) ou linoleico (Li). .44

Figura 6. Morfologia das feridas após 1 ( $A, B, C)$ e 24 horas (D, E, F) em ratos controle $(A, D)$ ou suplementados diariamente com acido oleico $(B, E)$ ou linoleico (C, F). $100 \mu \mathrm{m}$ 45

Figura 7. Ativação do fator de transcrição NF-kB em tecidos cicatriciais retirados após 1 (a) e 24 (b) horas da indução das feridas em animais controles (C) e suplementados com os ácidos oleico $(\mathrm{OL})$ ou linoleico $(\mathrm{Li})$. 46

Figura 8. Ativação do fator de transcrição AP-1 em tecidos cicatriciais retirados após 1 e 24 horas da indução das feridas em animais controles (C) e suplementados com os ácidos oleico $(\mathrm{OL})$ ou linoleico $(\mathrm{Li})$

Figura 9. Concentrações de CINC-2 $\alpha \beta$ (a), TNF- $\alpha$ (b), IL-1 $\beta$ (c), IL-6 (d) e MIP$3 \alpha$ (e) em feridas de animais controles (C) e tratados com os ácidos oleico (OL) ou linoleico ( $\mathrm{Li}$ ) e analisadas em diferentes períodos (0, 1, 24 e 120 horas) 
Figura 10. Expressão relativa do mRNA das citocinas CINC 2, IL-1 $\beta$, IL-6 e TNF- $\alpha$ em feridas de animais controles $(C)$ e tratados com os ácidos oleico $(\mathrm{OL})$ ou linoleico (Li) e analisadas 1 e 24 horas após a indução da ferida......................50

Figura 11. Esquema dos efeitos da administração dos ácidos oleico (OL) e linoleico

(Li) sobre o processo de cicatrização.

Figura 12. Viabilidade e fragmentação de DNA de neutrófilos isolados de ratos suplementados com os ácidos oléico ou linoléico. 54

Figura 13. Influxo de neutrófilos para a cavidade peritoneal, induzido por solução de glicogênio $(1 \%)$, em ratos controle suplementados com os ácidos oleico ou linoleico. 55

Figura 14. Expressão de L-selectina e $\beta$ 2-integrina em neutrófilos isolados da aorta abdominal de ratos controle $(\mathrm{C})$ ou suplementados $(0,22 \mathrm{~g} / \mathrm{kg}$ de peso corporal) com ácidos oleico (OL) ou linoleico (Li) 56

Figura 15. Rolling e aderência de neutrófilos em ratos controle (C) ou suplementados com $(0,22 \mathrm{~g} / \mathrm{kg}$ de peso corporal) os ácidos oléico (OL) ou linoléico (Li) 57

Figura 16. Influxo de neutrófilos (a) e concentração de CINC-2 $\alpha \beta$ (b) no exsudato inflamatório da bolsa de ar induzida em ratos controle (C) ou suplementados com os ácidos oléico (OL) ou linoléico (Li) 58

Figura 17. Concentrações de CINC-2 $\alpha \beta$ (a e b) e IL-1 $\beta$ (c e d) no sobrenadante de neutrófilos isolados do peritônio de ratos tratados com diferentes doses dos ácidos oléico ou linoléico. Neutrófilos foram incubados durante 4 horas na ausência (PBS) ou presença do estímulo (LPS - $5 \mu \mathrm{g} / \mathrm{mL}$ ).

Figura 18. Concentrações de CINC-2 $\alpha \beta$ ( $a$ e b) e IL-1 $\beta$ (c e d) no sobrenadante de neutrófilos isolados do peritônio de ratos suplementados com diferentes doses dos ácidos oléico ou linoléico. Neutrófilos foram incubados durante 18 horas na ausência (PBS) ou presença do estímulo (LPS-5 $\mu \mathrm{g} / \mathrm{mL})$ 


\section{LISTA DE ABREVIATURAS}

AGs - ácidos graxos

ALT - Alanina aminotransferase

AP-1 - proteína ativadora -1

AST - Aspartato aminotransferase

CINC - citocina indutora de quimiotaxia de neutrófilos

PDGF - fator de crescimento derivado de plaquetas

EMSA - ensaio de mobilidade eletroforética retardada

EPA - ácido eicosapentaenóico

ERO - espécies reativas de oxigênio

DHA - ácido docosahexaenóico

FGF - fator de crescimento de fibroblastos

fMLP - formil metionil-leucil-fenilalanina

$\mathrm{H}_{2} \mathrm{O}_{2}$ - peróxido de hidrogênio

ICAM - molécula de adesão intercelular

IL-1 $\beta$ - interleucina-1 $\beta$

IL-10 - interleucina-10

IL-6 - interleucina-6

IL-8 - interleucina-8

IP - iodeto de propídio

$\mathrm{LDH}$ - lactato desidrogenase

LPS - lipopolissacarídeo

$\mathrm{LTB}_{4}$ - leucotrieno $\mathrm{B}_{4}$

MIP - proteína inflamatória de macrófagos

mRNA - RNA mensageiro 
NF-kB - fator nuclear kappa B

PCR - reação em cadeia da polimerase

PKC - proteína quinase C

PBS - Tampão fosfato de sódio

PMSF - fluoreto de fenilmetanossulfonil

TGF- $\beta$ - fator de crescimento transformante $\beta$

TNF- $\alpha$ - fator de necrose tumoral- $\alpha$

VCAM - molécula de adesão vascular

VEGF - fator de crescimento vascular-endotelial 


\section{SUMÁRIO}

1 INTRODUÇÃO

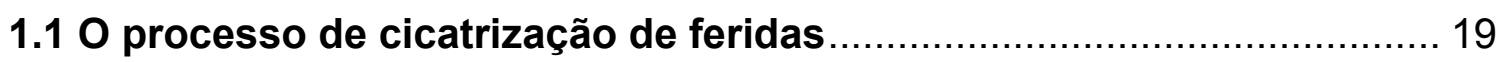

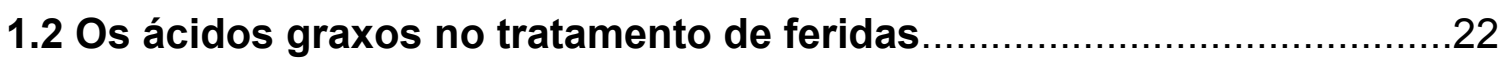

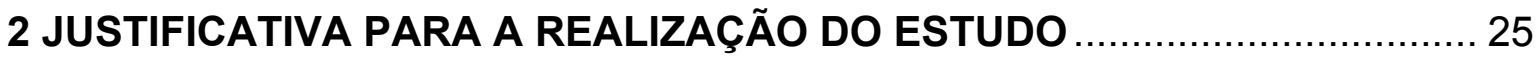

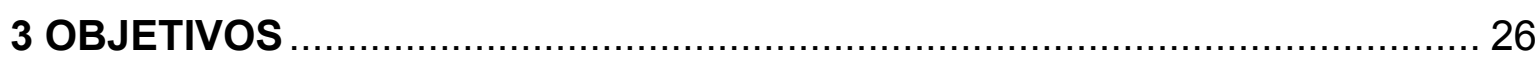

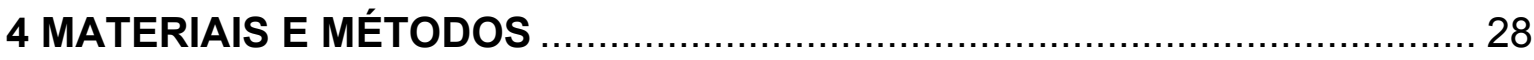

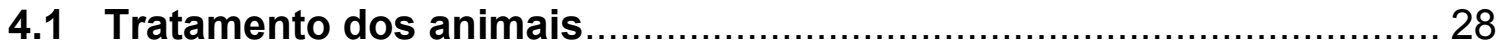

4.2 Administração dos ácidos oleico e linoleico ……………………..... 28

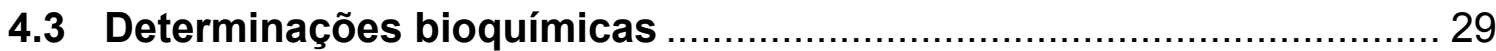

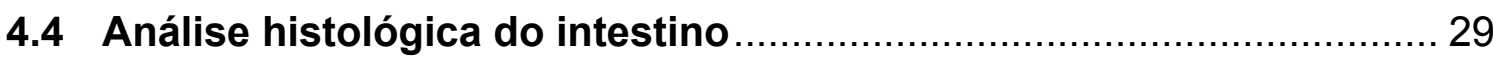

4.5 Migração de neutrófilos in vivo (bolsa de ar).................................... 29

4.6 Ensaio de migracao e obtenção de neutrófilos de rato para determinacao de citocinas................................................................. 30

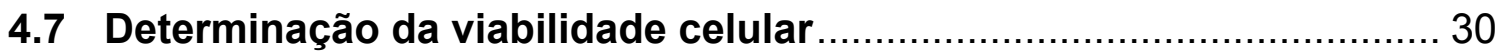

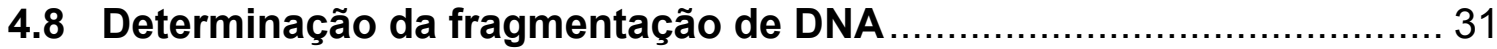

4.9 Produção de citocinas pró-inflamatórias (IL-1 $\beta$ e CINC-2 $\alpha \beta$ ) ............... 31

4.10 Avaliação da interação entre leucócitos e células endoteliais pela

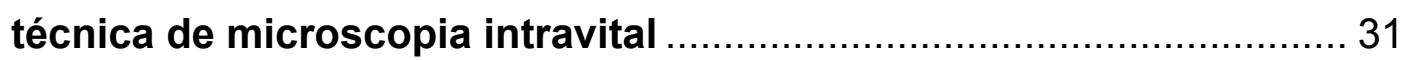

4.11 Análise da expressão de moléculas de adesão (L-selectina e $\beta 2$ integrina) por citometria de fluxo ................................................... 32

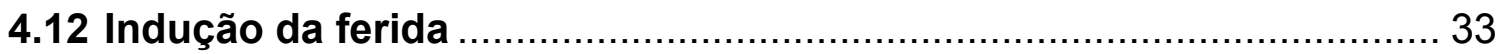

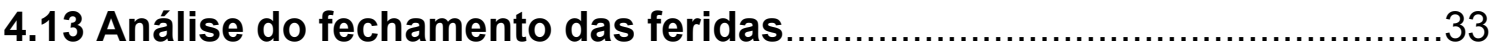

4.14 Determinação das concentrações de peróxido de hidrogênio $\left(\mathrm{H}_{2} \mathrm{O}_{2}\right)$ no

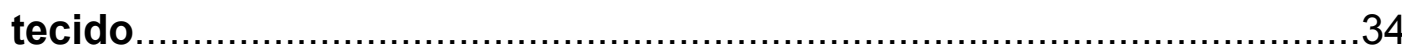

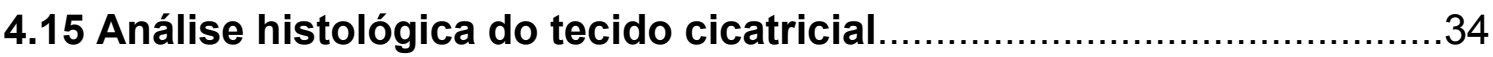

4.16 Ensaio de mobilidade eletroforética retardada em gel de poliacrilamida para análise da ativação dos fatores de transcrição NF-KB e AP-

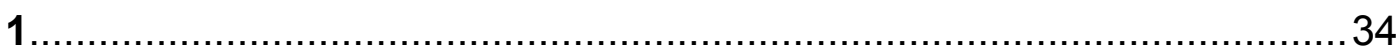

4.17 Homogeneização dos tecidos cicatriciais para determinação de

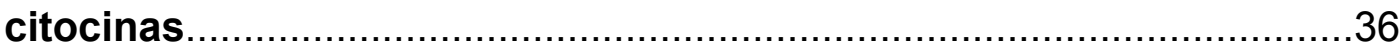


4.18 Avaliação da expressão gênica pela técnica de reação em cadeia de polimerase (PCR) em tempo real.......................................................

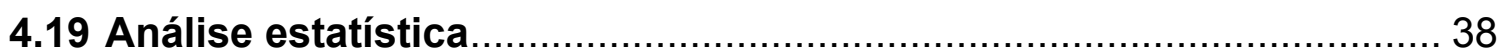

5 RESULTADOS

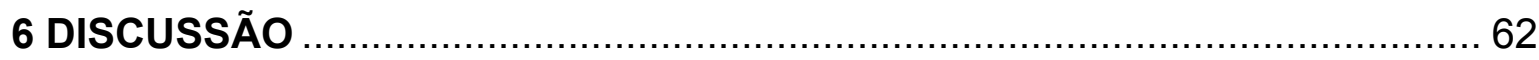

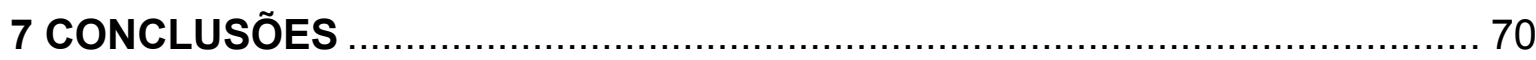

8 REFERÊNCIAS

ANEXO 


\section{1 - INTRODUÇÃO}

\subsection{0 processo de cicatrização de feridas}

O processo de cicatrização de feridas envolve uma cascata ordenada de eventos: inflamação, angiogênese, deposição de colágeno, reepitelização e formação de tecido de remodelamento (MARTIN, 1997). O objetivo destes eventos reparadores é impedir a invasão de patógenos e restabelecer a integridade dos tecidos danificados, reconstruindo assim a funcionalidade da pele (SINGER e CLARK, 1999). Este processo envolve grande variedade de células (neutrófilos, macrófagos, fibroblastos), fatores locais e sistêmicos como espécies reativas de oxigênio (EROs), citocinas, quimiocinas e fatores de crescimento (FC).

A fase inflamatória caracteriza-se pelo aparecimento de dor, calor, rubor e edema. A injúria geralmente causa ruptura nos vasos sanguíneos, com extravasamento dos constituintes do sangue para a região lesada. $O$ dano endotelial resulta na ativação de plaquetas e da cascata de coagulação, que leva à formação de uma camada de fibrina (MOORE, 1999). Em seguida, é formada uma matriz provisória para a migração celular.

A importância das EROs no processo de cicatrização foi verificada em estudos que utilizaram animais com mutações na estrutura da NADPH oxidase, principal responsável pela produção de EROs (JACKSON et al., 1995). No leito da ferida, as principais fontes de EROs são as células fagocíticas (macrófagos e neutrófilos) e as células não fagocíticas como fibroblastos, queratinócitos e células endoteliais (ROY et al., 2006) Em baixas concentrações, as EROs impedem a invasão de microrganismos e atuam como mensageiros celulares, interligando mecanismos de sinalização como a ativação de fatores de transcrição e a produção de citocinas pró-inflamatórias (RHEE, 1999). Em 2006, (ROY et al., 2006) estimaram as concentrações de EROs (aproximadamente $200 \mu \mathrm{M}$ ) em feridas. Neste estudo foi observado que o local da ferida é rico em peróxido de hidrogênio $\left(\mathrm{H}_{2} \mathrm{O}_{2}\right)$ e que a expressão do fator de crescimento vascular-endotelial (VEGF) e de seu receptor VEGFR-2 é modulada por esta ERO. Os autores observaram também 
aumento da vascularização e no número de células endoteliais em feridas tratadas com $\mathrm{H}_{2} \mathrm{O}_{2}$ (ROY et al., 2006).

O aumento na permeabilidade vascular é outro fator importante relacionado ao fechamento da ferida. A permeabilidade elevada dos vasos permite a deposição de matriz rica em fibrina, a que é fundamental para a migração celular (BROWN et al., 1988). A resposta migratória é um processo altamente regulado e envolve diversos mecanismos como a presença ou ausência de quimioatraentes específicos, a habilidade da célula em migrar ao longo de um gradiente quimiotático, a interação entre receptor-ligante e a expressão de moléculas de adesão na superfície das células inflamatórias e nos vasos sanguíneos (ROLLINS et al., 1991). Além desses fatores, a fluidez da membrana celular também modula a resposta quimiotática (WOLACH et al., 1992).

Uma vez no local da ferida, células inflamatórias como neutrófilos e macrófagos ativados desencadeiam a liberação de mediadores inflamatórios, como citocinas, quimiocinas, EROs e enzimas proteoliticas. A produção de citocinas próinflamatórias como interleucina $1 \beta$ (IL-1 $\beta$ ), interleucina 6 (IL-6) e o fator de necrose tumoral alfa (TNF- $\alpha$ ) ocorre rapidamente após o trauma. TNF- $\alpha$ e IL-1 são importantes na ativação de células endoteliais e na expressão de moléculas de adesão, fato que contribui para o recrutamento e acúmulo de mais fagócitos na área inflamada (MOLLINEDO et al., 1999). As moléculas de adesão são importantes na integração celular, pois promovem interações célula-célula e célula-matriz (TSIROGIANNI et al., 2006). As quimiocinas, por sua vez, contribuem para a regulação da epitelização, angiogênese e remodelamento do tecido (GILLITZER e GOEBELER, 2001). As proteínas inflamatórias para macrófagos (MIP-1 $\alpha$, MIP-1 $\beta$, MIP-2), proteína quimioatraente de macrófagos-1 (MCP-1) e a interleucina 8 (IL-8) são exemplos de quimiocinas (GILLITZER e GOEBELER, 2001; EFRON e MOLDAWER, 2004). As MIPs integram os eventos inflamatórios com os de reparo tecidual.

A produção de mediadores inflamatórios é finamente regulada. Um dos pontos de regulação é ativação/inibição de fatores de transcrição como o fator nuclear kappa B (NF-kB). O NF-kB é formado por subunidades citoplasmáticas que se encontram na forma inativa. Quando ativado, O NF-KB transloca para o núcleo e 
liga-se a região consenso de genes que expressam citocinas e enzimas oxidantes. A indução desta cascata de sinalização é necessária para que a resposta imune ocorra, entretanto, ela deve ser eficientemente desligada para evitar danos teciduais. O descontrole na resposta inflamatória está relacionado com a incidência de câncer e doenças autoimunes (KARIN, 2005). Outro importante fator de transcrição envolvido no reparo tecidual é a proteína ativadora-1 (AP-1). O AP-1 é constituído por diversas subunidades das famílias Jun e Fos (SHAULIAN e KARIN, 2001) e sua ativação e expressão é influenciada por interleucinas e o fator de crescimento transformante $\beta$ (TGF- $\beta$ ) (ANGEL et al., 2001). Animais knockout para uma ou mais subunidades do AP-1 apresentam cicatrização deficiente devido a alterações na fase de reepitelização (LI et al., 2003) e ao prolongamento da fase inflamatória (FLORIN et al., 2006).

$\mathrm{Na}$ fase proliferativa do processo de cicatrização ocorre neoangiogênese, produção de colágeno jovem pelos fibroblastos e intensa migração celular, principalmente de queratinócitos, promovendo a reepitelização. Inicialmente, os macrófagos ativados liberam PDGF, TGF- $\beta 1$ e fator de crescimento de fibroblastos (FGF), que estimulam a proliferação e a migração desses para a área lesada (GREILING e CLARK, 1997) e a síntese de glicosaminoglicanas, proteoglicanas e colágeno da nova matriz extracelular. Com o aumento do número de fibroblastos ativados, a matriz extracelular é substituída por tecido conjuntivo mais forte e elástico. Ao final da etapa proliferativa, o leito da ferida está totalmente preenchido por tecido de granulação.

A fase de remodelamento envolve etapas sucessivas de produção, digestão e orientação das fibrilas de colágeno, aumentando a sua resistência pelo fato de que a organização das fibras acompanha as forças mecânicas a que o tecido está sujeito durante a atividade normal. Ao final desta etapa, os anexos da pele, como folículos pilosos e glândulas sofrem regeneração limitada e a coloração da cicatriz permanece pálida, pois a regeneração dos melanócitos é deficiente e as cicatrizes são hipovascularizadas devido ao desaparecimento dos neocapilares.

Apesar da importância do tratamento de feridas pouco avanço foi alcançado nos últimos anos. $O$ uso de curativos em pacientes com feridas de difícil cicatrização 
tem como principal função a redução na perda de água e a contaminação por microrganismos. Atualmente, esses curativos são impregnados com sulfato de prata, fatores de crescimento ou ácidos graxos (BEAM, 2009; BERLANGA-ACOSTA et al., 2009).

\subsection{Os ácidos graxos no tratamento de feridas}

Os ácidos graxos (AG) são formados por uma cadeia hidrocarbonada e um grupamento carboxila terminal. Podem variar quanto ao número de carbonos na cadeia e a presença de duplas ligações. Os SFAs (ácidos graxos saturados) não apresentam dupla ligação; já os MUFAs (ácidos graxos monoinsaturados) possuem uma insaturação e os PUFAs (ácidos graxos poliinsaturados) apresentam duas ou mais insaturações. Com base no número e na posição das duplas ligações, os ácidos graxos de cadeia longa são classificados em três grandes famílias: $\omega-3, \omega-6$ e $\omega-9$.

Os AG da família $\omega-6$ (linoleico) e $\omega-3$ (a-linolênico) são classificados como AG essenciais, por não serem sintetizados pelo organismo humano, devendo, portanto, ser consumidos através da dieta. Entretanto, eles podem ser elongados e dessaturados. A metabolização do ácido linoleico (Li) resulta na formação do ácido araquidônico, enquanto que EPA (ácido eicosapentaenóico) e DHA (ácido docosaexaenóico) são os produtos finais da metabolização do ácido a-linolênico (CALDER et al., 2009). Quantidades excessivas de $\omega-6$ e o conseqüente aumento na relação $\omega-6 / \omega-3$ estão envolvidos na patogênese de diversas doenças autoimunes e inflamatórias, cardiovasculares e câncer (SIMOPOULOS, 2008). Essa associação é devida ao desequilíbrio entre a produção de mediadores pró e antiinflamatórios (SIMOPOULOS, 2008).

Nos países Ocidentais, a ingestão per capita diária de lipídios é de 35-40\% do consumo energético total (RISERUS, 2008). Entretanto, este valor pode variar entre menos de $20 \mathrm{~g} /$ dia (nos países em desenvolvimento) a mais de $100 \mathrm{~g} / \mathrm{dia}$ (nos países desenvolvidos). Além da quantidade, a composição dos ácidos graxos nos alimentos sofre grande variação nos diferentes países e tem mudado ao longo dos anos (CALDER et al., 2009) devido a diferenças na preparação dos alimentos. 
Em 1970 foram publicados os primeiros estudos com ácidos graxos e as células do sistema imune (PIETTE e SAUGIER, 1970).Desde então, é cada vez mais evidente o papel modulador desses lipídios sobre diversas funções celulares. Os AG podem interferir com o metabolismo e as funções celulares direta ou indiretamente: incorporação nas membranas celulares, participação na sinalização intracelular, ativação/inibição de fatores de transcrição e consequente modulação da expressão de genes. Além disso, alguns são precursores da síntese de eicosanóides (como o ácido araquidônico e o EPA), (MARTINS DE LIMA et al., 2007).

Os ácidos graxos consumidos podem ser incorporados às membranas celulares na forma de fosfolipídios, ácidos graxos livres ou ésteres de colesterol (CURI et al., 2002). Na forma esterificados, são hidrolisados pelas enzimas fosfolipases $A_{2}$ ou $C$ ou pela ativação da proteína quinase $C$ (PKC). Sabe-se que o conteúdo e a composição de fosfolipídios nos leucócitos são afetados pela disponibilidade dos ácidos graxos e do colesterol na dieta. Yaqoob (1998) demonstrou que aumentando o consumo de ácido oleico há maior incorporação deste ácido graxo nos fosfolipídios de células mononucleares isoladas do sangue. Os produtos gerados pela decomposição dos fosfolipídios atuam como segundo mensageiros influenciando cascatas de sinalização como a do NF-KB.

$\mathrm{Na}$ década de 80, Angel Keys iniciou os estudos sobre a dieta do Mediterrâneo (KEYS et al., 1986). A dieta dos povos do Mediterrâneo é rica em ácidos graxos monoinsaturados (principalmente o ácido oleico) e está associada à redução no risco de doenças cardiovasculares, diabetes e obesidade (GIUGLIANO e ESPOSITO, 2008). Contudo, muita controvérsia ainda existe sobre os nutrientes responsáveis pelos efeitos observados. Os principais candidatos são o ácido oleico e os agentes antioxidantes presentes no óleo de oliva extra-virgem (DE LORGERIL et al., 1999).

O ácido oleico (OL) não é essencial, uma vez que pode ser sintetizado de novo pelo organismo. A ingestão de OL é elevada em diversas populações, sendo o segundo ácido graxo mais consumido no mundo (US DEPARTMENT OF AGRICULTURE, 2008). O efeito do OL sobre as funções imunes é controverso. 
Alguns grupos têm demonstrado que o OL não apresenta ação imunomoduladora (YAQOOB et al., 1998; GRANATO et al., 2000) enquanto outros têm encontrado uma resposta supressora (TSANG et al., 1977; MOUSSA et al., 2000).

Embora a literatura sobre o uso de ácidos graxos no tratamento de feridas seja escassa, esta é uma prática comum em países em desenvolvimento, como o Brasil (PIEPER e CALIRI, 2003). O tratamento tópico com ácidos graxos está relacionado com a maior hidratação e elasticidade da pele, o que impede a entrada de microrganismos e a perda de água para o meio externo (DECLAIR, 1997). Contudo, os eventos moleculares e celulares envolvidos nesse processo não são conhecidos. 


\section{JUSTIFICATIVA PARA A REALIZAÇÃO DO ESTUDO}

O ácido oleico é encontrado em alguns óleos vegetais como o de palma, o óleo de oliva e na castanha de caju (FOUNDATION, 1992). O ácido linoleico também tem ampla distribuição nos alimentos, sendo suas principais fontes os óleos vegetais como o de soja e canola (FOUNDATION, 1992). Assim, os ácidos oleico e linoleico são os mais abundantes nas dietas ocidentais. A variação no consumo destes lipídios pode influenciar o aparecimento/desenvolvimento de doenças crônicas, principalmente aquelas com algum componente inflamatório como diabetes, obesidade e síndrome metabólica.

Considerando a presença constante de OL e Li na dieta ocidental e que estes ácidos graxos modulam diferentes funções de células do sistema imune, envolvidas no processo de reparo tecidual, investigamos os efeitos desses ácidos graxos sobre o processo de cicatrização de feridas. 


\section{OBJETIVOS}

O objetivo geral deste trabalho foi caracterizar o processo de cicatrização em ratos e determinar os efeitos da ingestão de OL e Li no processo de reparo tecidual, através de ensaios in vivo e ex vivo assim esquematizados (Figura 1):

In vivo: - Avaliar os efeitos da ingestão de OL e Li sobre o fechamento de feridas em ratos. Neste sentido, foram monitorados: (a) parâmetros nutricionais; (b) análise macroscópica do processo de cicatrização (área e celularidade); (c) expressão e quantificação local de citocinas e fatores de crescimento, (d) ativação de fatores de crescimento e (e) ensaios de rolling, aderência e migração de neutrófilos.

Ex vivo: Estudar os efeitos dos ácidos graxos na migração e na liberação de citocinas e fatores de crescimento por neutrófilos. 


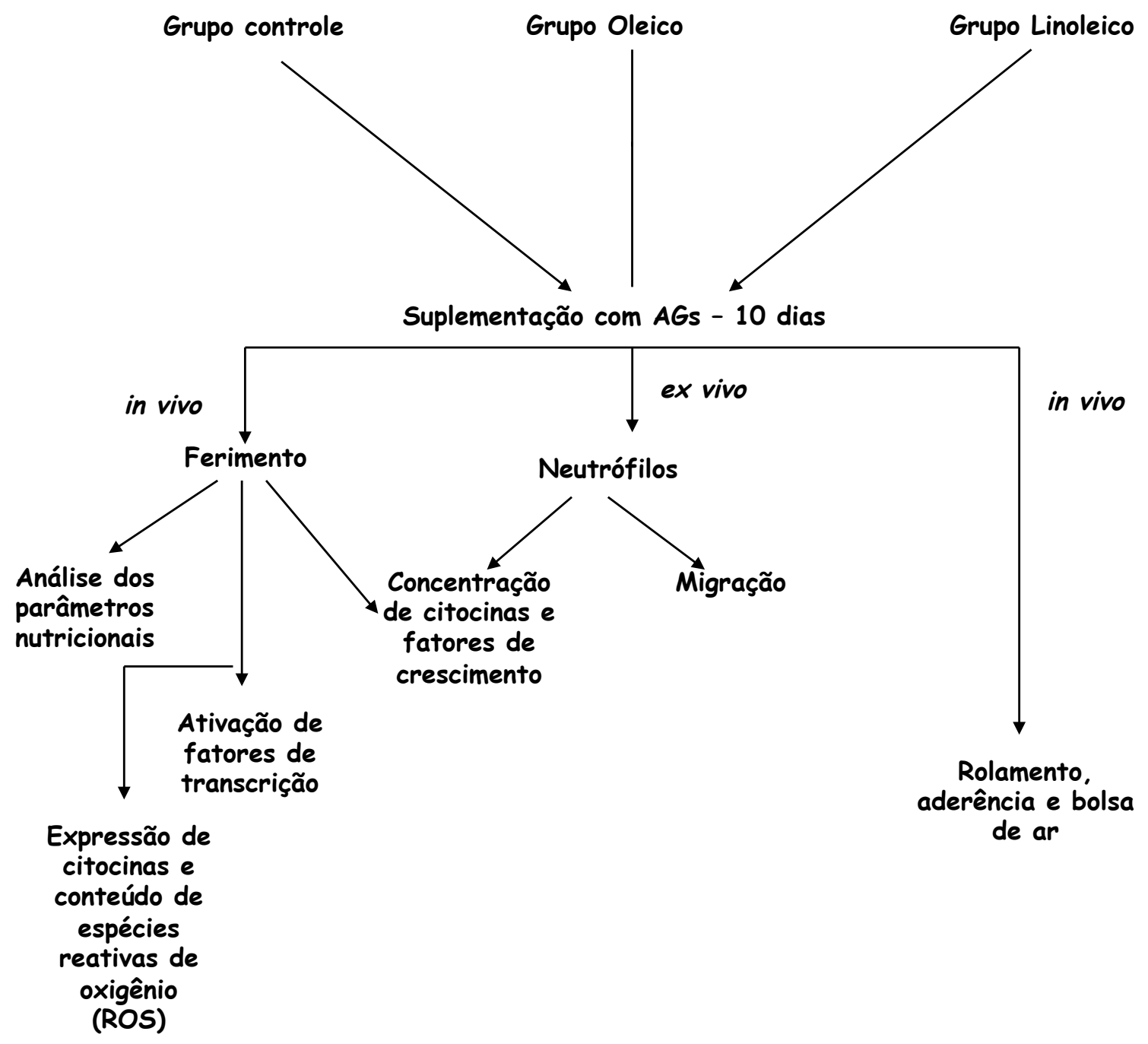

Figura 1. Fluxograma dos ensaios propostos no projeto. 


\section{MATERIAIS E MÉTODOS}

\section{Reagentes}

Os ácidos graxos (oleico e linoleico), lipopolissacarídeo de E.coli sorotipo 026:B6, L-glutamina, Hepes, meio de cultura RPMI 1640, estreptomicina, penicilina, soro fetal bovino, EDTA, flúor fenilmetanosulfonil (PMSF), aprotinina e glicose foram obtidos da Sigma Chemical Co. (St. Louis, MO). Os kits DuoSet para determinação das citocinas foram adquiridos da R\&D Systems (Minneapolis, MN, EUA). Os anticorpos para $\beta 2$-integrina e Lselectina foram obtidos da BD Biosciences (EUA). Amplex Ultrared ${ }^{\circledR}$ foi obtido da Invitrogen (Carlsbad, CA, USA).

\subsection{Tratamento dos animais}

Ratos machos wistar $(180 \pm 20 \mathrm{~g})$ foram provenientes do biotério do Departamento de Fisiologia e Biofísica do Instituto de Ciências Biomédicas da Universidade de São Paulo. Os ratos foram mantidos em ambiente controlado a temperatura de $23^{\circ} \mathrm{C}$, sob ciclo claro: escuro de 12 horas e tiveram livre acesso a ração e água.

Os ratos foram divididos em 3 grupos: (C) controle; (OL) animais que receberam ácido oleico por gavagem e (Li) animais que receberam ácido linoleico por gavagem.

Todos os procedimentos realizados neste estudo foram aprovados pela Comissão de Ética em Experimentação Animal (CEEA) do Instituto de Ciências Biomédicas da Universidade de São Paulo (protocolo nº 86).

\subsection{Administração dos ácidos oleico e linoleico}

Os ácidos graxos foram administrados através de gavagem $(0,22 \mathrm{~g} / \mathrm{kg}$ de peso corporal/dia) durante 10 dias. Essa dose foi escolhida após os testes iniciais de 
migração de neutrófilos para o peritônio com as doses de 0,11;0,22 e 0,44 g/kg de peso corporal/dia dos ácidos graxos.

\subsection{Determinações bioquímicas}

Amostras de sangue foram coletadas e mantidas no gelo durante 30 minutos para ocorrer a coagulação. Após centrifugação a 1000 x g por 10 minutos, o soro foi coletado e armazenado a $-20{ }^{\circ} \mathrm{C}$. As atividades séricas das enzimas alanina transaminase (ALT), aspartato transaminase (AST) e lactato desidrogenase (LDH) foram determinadas utilizando os kits BioClin (Belo Horizonte, Brasil) e Wako chemicals (Neuss, Alemanha).

\subsection{Análise histológica do intestino}

A análise histológica do intestino delgado foi realizada sem o prévio conhecimento de quais grupos estavam sendo analisados. Foram analisados aspectos gerais do intestino delgado como: relação vilosidade/criptas, número de linfócitos intraepiteliais, número de células inflamatórias e camada muscular.

\subsection{Migração de neutrófilos in vivo (bolsa de ar)}

O efeito da administração oral dos ácidos oleico e linoleico sobre a migração de neutrófilos in vivo foi avaliado através da indução de bolsa de ar estéril no tecido subcutâneo do dorso de ratos anestesiados conforme descrito previamente (EDWARDS et al., 1981; FARSKY et al., 2004). Resumidamente, injetou-se $20 \mathrm{~mL}$ de ar estéril (usando filtros com poros de 0,22 $\mu \mathrm{m}$ ) no dorso de ratos anestesiados. Após 7 dias, nova injeção de ar foi realizada. Controles negativos receberam $1 \mathrm{~mL}$ de tampão PBS estéril e nos controles positivos aplicou-se $1 \mathrm{~mL}$ de tampão PBS contendo fMLP na concentração de $10 \mathrm{nM}$.

Quatro horas após a injeção do estímulo, os animais foram decapitados e o exsudato inflamatório foi coletado por lavagem da cavidade com $2 \mathrm{~mL}$ de PBS. A suspensão foi centrifugada a $1200 \mathrm{rpm}$ por $10 \mathrm{~min}$ a $4{ }^{\circ} \mathrm{C}$. O sobrenadante obtido foi separado para determinação de citocinas (IL-1 $\beta$ e CINC-2 $\alpha \beta$ ) e o precipitado foi 
ressuspenso em $1 \mathrm{~mL}$ de PBS. O número de células foi contado em câmara de Neubauer.

\subsection{Ensaio de migração e obtenção de neutrófilos de rato para determinação de citocinas}

Para a obtenção dos neutrófilos, injetou-se $(10 \mathrm{~mL})$, intraperitonealmente, de solução de glicogênio de ostra (Sigma, Tipo II) a 1\% em PBS e, após 4 horas, os ratos foram sacrificados por decapitação. A coleta das células foi realizada lavandose a cavidade peritoneal com cerca de $40 \mathrm{~mL}$ de PBS estéril. Em seguida, as células foram centrifugadas a $1200 \mathrm{rpm}$ por 10 minutos a $4{ }^{\circ} \mathrm{C}$. Descartou-se o sobrenadante e as células foram ressuspensas e mantidas em solução hipotônica de cloreto de amônio por 10 minutos a $4{ }^{\circ} \mathrm{C}$ para lise das hemáceas. Após essa etapa, as células foram centrifugadas a $1200 \mathrm{rpm}$ por 10 minutos a $4{ }^{\circ} \mathrm{C}$, lavadas com PBS e, posteriormente, ressuspensas em meio RPMI-1640, enriquecido com $10 \%$ de soro fetal bovino, glutamina $2 \mathrm{mM}$, tamponado com bicarbonato de sódio 24 mM, HEPES $20 \mathrm{mM}$ e adicionado os antibióticos (10000 U/mL de penicilina e 10000 $\mu \mathrm{g} / \mathrm{mL}$ de estreptomicina). A contagem de células foi realizada em câmara de Neubauer utilizando líquido de Turk como diluente.

\subsection{Determinação da viabilidade celular}

A avaliação da integridade da membrana celular foi realizada utilizando-se iodeto de propídio (IP), que é um composto fluorescente altamente solúvel em água e que não atravessa membranas intactas, de modo que apenas nas células com perda da integridade de membrana, o IP entra e se intercala entre as bases do DNA. A fluorescência foi detectada no canal FL2. Foram adquiridos 10.000 eventos por amostra e a análise foi, posteriormente, realizada utilizando-se o programa Cell Quest (Becton Dickinson, San Juan, California, EUA).

Para a análise da integridade da membrana (viabilidade celular), as células foram centrifugadas e o precipitado foi ressuspenso em $500 \mu \mathrm{L}$ de PBS, ao qual foram adicionados $50 \mu \mathrm{L}$ de solução de iodeto de propídio (IP) $(20 \mu \mathrm{g} / \mathrm{mL})$. As 
células foram imediatamente analisadas no citômetro de fluxo FACS Calibur (Becton Dickinson, San Juan, California, EUA).

\subsection{Determinação da fragmentação de DNA}

A análise da fragmentação de DNA foi realizada de acordo com o método descrito por Nicoletti et al. (1991). As células foram centrifugadas e o precipitado foi ressuspenso em $300 \mu \mathrm{L}$ de solução hipotônica contendo $50 \mu \mathrm{g} / \mathrm{mL}$ de $\mathrm{IP}, 0,1 \%$ de citrato de sódio e $0,1 \%$ de Triton X-100. O triton X-100 permite a entrada do IP, que se incorpora ao DNA. Quanto mais fragmentado o DNA maior é a incorporação de IP e a fluorescência emitida. A fluorescência foi analisada como descrito acima.

\subsection{Produção de citocinas pró-inflamatórias}

A produção de citocinas foi avaliada no sobrenadante das culturas de neutrófilos, no exsudato inflamatório e no homogenato das feridas, através do método de ELISA utilizando o Kit Duo Set (R\&D System, Mineapolis, MN, USA).

Para quantificação das citocinas no sobrenadante da cultura de neutrófilos, as células foram cultivadas a $37^{\circ} \mathrm{C}$, em atmosfera com $5 \%$ de $\mathrm{CO}_{2}$, em placas de cultura de 24 poços contendo RPMI-1640 com soro fetal bovino (10\%). Foram plaqueadas $2,5 \times 10^{6}$ células por $\mathrm{mL}$. A concentração de LPS utilizada foi de 5 $\mu \mathrm{g} / \mathrm{mL}$ e o sobrenadante foi coletado após 4 e 18 horas de incubação. O sobrenadante das culturas foi obtido por centrifugação (1200 rpm, 10 minutos) e congelado $\left(-80^{\circ} \mathrm{C}\right)$ para posterior determinação das citocinas. A quantificação das citocinas foi realizada de acordo com procedimento descrito no kit Duo Set (R\&D System, Mineapolis, MN, USA).

\subsection{Avaliação da interação entre leucócitos e células endoteliais pela técnica de microscopia intravital}

Ratos suplementados com os ácidos oleico, linoleico ou água (controle) foram anestesiados uma hora após o tratamento e tiveram o mesentério exteriorizado. Após cirurgia, os animais foram mantidos em placa com temperatura de $37^{\circ} \mathrm{C}$, que 
incluía uma plataforma na qual o tecido a ser transiluminado foi posicionado. A preparação foi mantida umidecida e aquecida através da irrigação do tecido com solução Ringer-Locke (pH: 7,2- 7,4; $\mathrm{NaCl} 154$ mM; KCl 5,6 mM; $\mathrm{CaCl}_{2} \cdot 2 \mathrm{H}_{2} \mathrm{O} 2 \mathrm{mM}$; $\mathrm{NaHCO}_{3} 6 \mathrm{mM}$ e glicose $5 \mathrm{mM}$ ) aquecida contendo $1 \%$ de gelatina. $\mathrm{O}$ tecido exposto foi mantido em contato com um filme líquido fino. As imagens foram obtidas por microscópio óptico (Axioplan II, equipado com objetivas de 5,0x/0,30 planneofluar ou 10,0 x/0,25 Achroplan). As imagens foram capturadas por câmera de vídeo (ZVS, 3C75DE, Carl Zeiss) e transmitidas simultaneamente para o monitor da TV e o computador. As imagens obtidas foram gravadas em computador, digitalizadas e analisadas usando o software KS 300 (Kontron, Munich, Alemanha).

A interação dos leucócitos com as células endoteliais das paredes dos vasos foi analisada pela determinação do número de células aderidas e rolando na parede de vênulas pós-capilares (20-30 $\mu \mathrm{m}$ diâmetro, $200 \mu \mathrm{m}$ comprimento) do mesentério. Três campos de cada animal foram avaliados. Leucócitos movendo-se no fluxo axial periférico, em contato com o endotélio, foram contados como células rolando (DAHLEN et al., 1981). Esses leucócitos se moviam lentamente o suficiente para serem individualmente visualizados. A contagem de leucócitos rolando foi feita durante 10 minutos. O número de leucócitos aderidos ao endotélio (parados na parede dos vasos por mais de 30 segundos) foi determinado no mesmo segmento de $200 \mu \mathrm{M}$. A administração tópica de fMLP (10 nM) foi utilizada como controle positivo dos experimentos.

\subsection{Análise da expressão de moléculas de adesão (L-selectina e $\beta 2$ - integrina) por citometria de fluxo}

O sangue foi coletado da aorta abdominal e tratado com EDTA (100 mg/mL). Os neutrófilos foram isolados utilizando gradiente Histopaque. A cada $3 \mathrm{~mL}$ de Histopaque-1077 adicionou-se o mesmo volume de sangue. O sangue foi adicionado cuidadosamente, pela parede, ao tubo contendo solução Histopaque para não ocorrer mistura entre as camadas. O tubo foi então centrifugado a $400 \mathrm{x} \mathrm{g}$, $4{ }^{\circ} \mathrm{C}$, por 30 minutos. Ao final da centrifugação, três fases eram identificadas. As duas superiores (plasma, células mononucleares e Histopaque-1077) foram 
descartadas e a inferior, rica em neutrófilos e eritrócitos, foi ressuspensa em PBS. A lise dos eritrócitos foi realizada usando solução de cloreto de amônio $(0,13 \mathrm{M})$ e os leucócitos foram recuperados após lavagem com PBS. Usando essa metodologia de separação, preparações ricas em neutrófilos (mais de $90 \%$ dos leucócitos, conforme avaliado em microscópio óptico) foram obtidas.

Neutrófilos $\left(1,0 \times 10^{6}\right)$ foram estimulados com $\mathrm{N}$-formil-metionil-leucilfenilalanina (fMLP; $10 \mathrm{nM}$ ) durante 10 minutos para avaliação de L-selectina e 30 minutos para $\beta 2$-integrina. Após lavagem, os leucócitos foram incubados por 30 minutos a $4{ }^{\circ} \mathrm{C}$ no escuro com $10 \mu \mathrm{L}$ de anticorpo monoclonal anti-CD62L ou anti$\beta 2$-integrin. Após incubação, as células foram analisadas em citômetro de fluxo FACScalibur (Becton \& Dickinson, San Jose, CA, USA). Foram analisadas 10.000 células de cada amostra. Os resultados foram normalizados pela fluorescência média dos controles (PBS).

\subsection{Indução da ferida}

Após 5 dias de administração dos ácidos graxos, os animais foram anestesiados e uma área de aproximadamente $10 \mathrm{~mm}^{2}$ de pele foi removida cirurgicamente da região dorsal. Os ratos foram eutanaziados nos períodos de 1 hora, 24 horas e 120 horas após a indução da ferida. Os animais foram suplementados diariamente durante todo o período experimental.

\subsection{Análise do fechamento das feridas}

Para avaliar o fechamento das feridas, as mesmas foram fotografadas diariamente com câmera cyber shot Sony (DSC-S950S 4X 10MP com zoom ótico) pelo mesmo examinador. Após a digitalização, a área da ferida foi medida utilizando o programa Image J. Os resultados foram expressos em porcentagem (\%) da área da ferida original. 


\subsection{Determinação das concentrações de peróxido de hidrogênio $\left(\mathrm{H}_{2} \mathrm{O}_{2}\right)$ no tecido}

As feridas foram incubadas por 1 hora em 1,5 $\mathrm{mL}$ de tampão Krebs- Ringer (contendo em mM: $\mathrm{NaCl} 118,5, \mathrm{NaHCO}_{3} 24,7, \mathrm{KCl} 4,7, \mathrm{MgSO}_{4}$ 1,18, $\mathrm{KH}_{2} \mathrm{PO}_{4}$ 1,18,

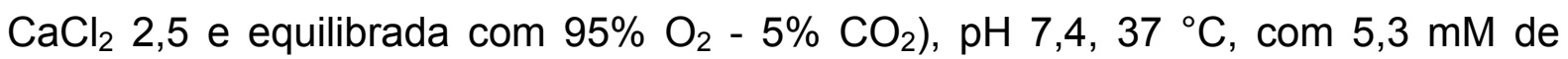
glicose, $1 \%$ de BSA na presença do reagente Amplex UltraRed® $(50 \mu \mathrm{M})$ e HRP do inglês horseradish peroxidase - $(0.1 \mathrm{U} / \mathrm{ml})$. Após este período, foram coletados $20 \mu \mathrm{L}$ do meio e a intensidade da fluorescência foi determinada em fluorímetro com os comprimentos de onda de 530 nm de excitação e 590 nm de emissão. O Amplex (N-acetil-3,7-diidroxifenoxazina) atua como doador de elétrons para a reação de redução do $\mathrm{H}_{2} \mathrm{O}_{2}$ catalisada pela HRP, na proporção de 1:1 (ZHOU et al., 1997). O produto da oxidação do Amplex pela HRP é denominado resorufina, um composto vermelho, estável e fluorescente, que pode ser quantificado por fluorimetria, sendo uma evidência indireta da quantidade de peróxido de hidrogênio na amostra (ZHOU et al., 1997).

\subsection{Análise histológica do tecido cicatricial}

A ferida e a pele adjacente foram retiradas e fixadas em Bouin por 24 horas, em temperatura ambiente, processadas e embebidas em Paraplast $\circledast$. As peças foram cortadas em fatias de $7 \mu \mathrm{m}$ e coradas com hematoxilina/eosina para avaliarmos aspectos gerais da ferida.

\subsection{Ensaio de mobilidade eletroforética retardada em gel de poliacrilamida para análise da ativação dos fatores de transcrição NF-kB e AP-1}

As atividades dos fatores de transcrição NFKB e AP-1 foram avaliadas utilizando EMSA. Neste ensaio, o extrato protéico nuclear é incubado com um oligonucleotídeo dupla fita de DNA contendo a seqüência consenso do fator de transcrição marcado radioativamente. $O$ fator de transcrição ativo se liga ao oligonucleotídeo e após eletroforese em gel de poliarilamida, em condições não- 
desnaturantes, pode ser quantificado. Sob essas condições, o complexo oligo-NFKB apresenta mobilidade menor que o oligo não ligado ao fator de transcrição.

A seqüência dupla fita utilizada no ensaio para avaliar a ativação do NF-KB e do AP-1 está descrita abaixo:

NF-KB: 5'- AGTTGAGGGGACTTTCCCAGGC- 3'

\section{AP-1: 5' - CGCTTGATGAGTCAGCCGGAA - 3'}

Os oligonucleotídeos foram marcados por fosforilação da extremidade 5' com [Y ${ }^{32}$ P]-ATP (GE Healthcare Life Sciences) catalisada pela enzima T4 polinucleotídeo quinase (Life Technologies). A reação, que continha 10 pmol de oligonucleotídeo, 15 pmol de [Y ${ }^{32}$ P]-ATP, $1 \mathrm{U}$ de T4 quinase e tampão de enzima $1 \mathrm{X}$, foi incubada a 37 ${ }^{\circ} \mathrm{C}$ por 1 hora. A reação foi interrompida pela adição de tampão TE (Tris $\mathrm{HCl} 10$ $\mathrm{mM})$, EDTA $1 \mathrm{mM}, \mathrm{pH} 8,0)$ contendo $\mathrm{NaCl}(0,1 \mathrm{M})$ e o excesso de $\left[\mathrm{r}^{32} \mathrm{P}\right]-\mathrm{ATP}$ foi removido por centrifugação do volume da reação utilizando colunas MicroSpin S300 HR (GE Healthcare Life Sciences).

Os tecidos retirados nos períodos de 1 e 24 horas foram homogeneizados em tampão (HEPES $10 \mathrm{mM}, \mathrm{MgCl}_{2}$ 1,5mM, $\mathrm{KCl} 10 \mathrm{mM}$, DTT 0,5 mM e PMSF 0,2 mM). $O$ homogenato foi centrifugado a $900 \times \mathrm{g}$ por 10 minutos e o sedimento contendo as

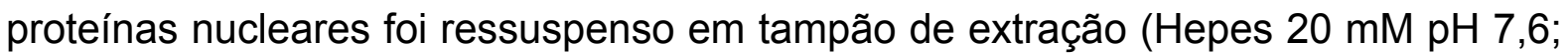
$\mathrm{NaCl}$ 0,45 M; EDTA 2,5 mM; glicerol $25 \%$; DTT 2,5 mM; PMSF $1 \mathrm{mM}$ ). Após incubação por 30 minutos a $4{ }^{\circ} \mathrm{C}$ sob agitação, a suspensão foi centrifugada por 10 min a $4{ }^{\circ} \mathrm{C}$ na rotação máxima e o sobrenadante contendo as proteínas nucleares foi armazenado a $-70{ }^{\circ} \mathrm{C}$. As proteínas nucleares foram quantificadas conforme descrito por Bradford (1976).

Para a formação dos complexos proteína-DNA, as reações (volume final de $20 \mu \mathrm{L}$ ) foram preparadas em gelo, contendo $30 \mu \mathrm{g}$ de extrato nuclear, 1,5 $\mu \mathrm{g}$ de Poli dl-dC, 1 pmol de oligonucleotídeo marcado e $6 \mu \mathrm{L}$ de tampão de ligação (Hepes $60 \mathrm{mM} \mathrm{pH} \mathrm{7,6;} \mathrm{glicerol} \mathrm{10 \% ;} \mathrm{KCl} 150$ mM; EDTA 0,6 mM e DTT $3 \mathrm{mM}$ ). As reações foram incubadas à temperatura ambiente por 20 minutos. A seguir, as amostras foram aplicadas em gel contendo $6 \%$ de poliacrilamida (30:1) em tampão TBE (Tris base $45 \mathrm{mM}$, ácido bórico $45 \mathrm{mM}$ e EDTA $1 \mathrm{mM}$ ) e submetidas à eletroforese a 150 
$\checkmark$ por 2 horas. Após eletroforese, o gel foi seco a vácuo a $80^{\circ} \mathrm{C}$ e exposto em um filme de raio-X por uma semana. Os resultados foram analisados por densitometria utilizando o equipamento STORM 840 (Dynamic Molecular, Sunnyvale, USA).

\subsection{Homogeneização dos tecidos cicatriciais para determinação de citocinas}

Os tecidos retirados nos períodos de 1, 24 e 120 horas, após a indução das feridas, foram imediatamente acondicionados em gelo seco e mantidos no freezer ($80^{\circ} \mathrm{C}$ ) até serem homogeneizados.

Para homogeneização, foi preparado tampão PBS com inibidores de proteinases (PMSF 0,5 M e aprotinina $500.000 \quad \mathrm{UI}$ ). Foram pesados, aproximadamente, $100 \mathrm{mg}$ de tecido para serem homogeneizados. Após a homogeneização, as amostras foram sonicadas durante 1 minuto e centrifugadas a $1000 \mathrm{~g} \mathrm{a} 4{ }^{\circ} \mathrm{C}$ durante 10 minutos. $\mathrm{O}$ sobrenadante foi recolhido e armazenado a -20 ${ }^{\circ} \mathrm{C}$.

A produção de citocinas (CINC-2 $\alpha \beta$, IL-1 $\beta$, TNF- $\alpha$, IL-6, MIP-3 e VEGF) foi avaliada através do método de ELISA utilizando o Kit Duo Set (R\&D System, Mineapolis, MN, USA). Os valores foram normalizados pela quantidade de proteínas nas amostras, determinada pelo método de Bradford (1976).

\subsection{Avaliação da expressão gênica pela técnica de reação em cadeia de polimerase (PCR) em tempo real}

A avaliação do conteúdo de RNA mensageiro (mRNA) das citocinas (CINC2, IL-1 $\beta$, IL-6, TNF- $\alpha$, MIP-3 e VEGF) foi realizada pela técnica de PCR em tempo real (HIGUCHI et al., 1992), usando o equipamento ROTOR GENE 3000 (Corbett Research, Mortlake, Australia).

O RNA total do tecido das feridas foi obtido usando o Kit RNAeasy (Quiagen, Maryland, USA) conforme descrito pelo fabricante. Resumidamente, o tecido foi homogeneizado com $1 \mathrm{~mL}$ de Quiazol e, após 5 minutos de incubação à temperatura ambiente, $200 \mu \mathrm{L}$ de clorofórmio foram adicionados aos tubos e centrifugados a $12.000 \mathrm{rpm}$. A fase aquosa foi transferida para outro tubo e foram 
adicionados $600 \mu \mathrm{L}$ de etanol a $70 \%$. A solução foi transferida para a coluna do kit e após um pulso o RNA foi retido na coluna. Após lavagem com o tampão RW1 do kit, foram adicionados $80 \mu \mathrm{L}$ de DNAse (Quiagen, Maryland, USA) e as amostras foram incubadas em temperatura ambiente durante 15 minutos. Nova lavagem foi realizada e em seguida a amostra foi ressuspensa em água livre de RNase. O RNA foi armazenado a $-70{ }^{\circ} \mathrm{C}$ até que a transcrição reversa fosse realizada. O RNA foi quantificado através da medida da sua absorbância a $260 \mathrm{~nm}$. A pureza do RNA foi avaliada pela razão 260/280 nm (SAMBROOK, 2001).

O cDNA foi sintetizado utilizando $3 \mu \mathrm{g}$ de RNA e $4 \mu \mathrm{L}$ do kit de transcrição reversa de cDNA de alta capacidade (High-Capacity cDNA Reverse Transcription kit Applied Biosystems, Foster City, CA) em volume final de $20 \mu \mathrm{L}$. A reação foi incubada por 2 minutos a $25^{\circ} \mathrm{C}$, seguida por aquecimento a $42{ }^{\circ} \mathrm{C}$ por 30 minutos e mais 5 minutos a $85^{\circ} \mathrm{C}$. O cDNA foi armazenado a $-20^{\circ} \mathrm{C}$ até a realização da PCR.

Para a realização da reação de PCR, $1 \mu \mathrm{L}$ de cDNA foi adicionado a um volume final de $25 \mu \mathrm{L}$, contendo $100 \mu \mathrm{M}$ de dNTPs, tampão de reação 10X (10 mM Tris- $\mathrm{HCl}, 50 \mathrm{mM} \mathrm{KCl}, 2 \mathrm{mM} \mathrm{MgCl}$ ), $1 \mathrm{U}$ de Taq DNA polimerase (Invitrogen Life Technologies, Rockville, MD, USA), 0,1 $\mu \mathrm{M}$ de cada primer (sense e antisense) e SYBR GREEN (1000× diluído) (Invitrogen Life Technologies, Rockville, MD, USA) como sonda fluorescente. As seqüências dos primers foram desenhadas usando informação disponível no GeneBank do National Center for Biotechnology Information (NCBI). A seqüência dos primers está mostrada na Tabela 1. A quantificação da expressão gênica foi realizada de acordo com método previamente descrito (LIU e SAINT, 2002), usando o gene GAPDH (housekeeping) como controle interno. 
Tabela 1 Sequência dos primers utilizados

\begin{tabular}{ll}
\hline Gene & Sequência das bases \\
\hline CINC-2 & 5' TGT ACT GGT CCT GCT CCT CCT GAT 3' \\
IL-1 $\beta$ & 5' AGG CAG TGT CAC TCA TTG TGG CTT 3' \\
TNF-a & 5' GCC TCT TCT CAT TCC TGC TCG TGG 3' \\
IL-6 & 5' CCT TCT TGG GAC TGA TGT TGT TGA 3' \\
MIP-3 & 5' GCC AGT CAG AAG CAG CAA GCA ACT 3' \\
GAPDH & 5' TGC CAT CAC TGC CAC TCA-3' \\
\hline
\end{tabular}

\subsection{Análise estatística}

Os resultados estão apresentados como média \pm erro padrão da média. Comparações entre os grupos foram realizadas por análise de variância (ANOVA) e pós-teste de Dunnett ou Tukey. Para a realização das análises estatísticas, foi utilizado o programa Prisma 3.0 (Graph Pad Software, Inc., San Diego, CA, USA). As diferenças foram consideradas significantes para $p<0,05$. 


\section{RESULTADOS}

A suplementação com OL e Li não alterou o estado nutricional dos animais, uma vez que não houve mudanças significativas no ganho de peso, consumo alimentar, ingestão calórica e ingestão de água (Tabela 2). Assim, a suplementação não alterou a ingestão de micronutrientes.

Tabela 2 Consumo de ração, ingestão calórica e ingestão de água em ratos controles (C) e suplementados com os ácidos oleico (OL) ou linoleico ( $\mathrm{Li})$.

\begin{tabular}{|c|c|c|c|c|}
\hline \multicolumn{5}{|c|}{ ÁCIDO OLEICO (g/kg de peso corporal) } \\
\hline Doses & 0 & 0,11 & 0,22 & 0,44 \\
\hline $\begin{array}{l}\text { Consumo de } \\
\text { ração } \\
\text { (g/dia) }\end{array}$ & $23,0 \pm 0,9$ & $20,6 \pm 0,3$ & $22,1 \pm 0,8$ & $22,5 \pm 0,9$ \\
\hline $\begin{array}{c}\text { Ingestão calórica } \\
\text { (Kcal/dia) } \\
\text { Inqestão de áqua }\end{array}$ & $69,0 \pm 2,7$ & $62,1 \pm 1,1$ & $67,0 \pm 2,5$ & $68,6 \pm 1,2$ \\
\hline$(\mathrm{mL} / \mathrm{dia})$ & $37,5 \pm 1,7$ & $35,5 \pm 0,8$ & $41,7 \pm 2,7$ & $40,0 \pm 1,5$ \\
\hline \multicolumn{5}{|c|}{ ÁCIDO LINOLEICO (g/kg de peso corporal) } \\
\hline & 0 & 0,11 & 0,22 & 0,44 \\
\hline $\begin{array}{l}\text { Consumo de } \\
\text { ração } \\
\text { (g/dia) }\end{array}$ & $23,0 \pm 0,9$ & $20,5 \pm 0,2$ & $20,6 \pm 1,6$ & $21,0 \pm 0,6$ \\
\hline $\begin{array}{c}\text { Ingestão calórica } \\
\text { (Kcal/dia) } \\
\text { Ingestão de água }\end{array}$ & $69,0 \pm 2,7$ & $61,8 \pm 0,8$ & $62,4 \pm 5,0$ & $63,9 \pm 1,9$ \\
\hline$(\mathrm{mL} / \mathrm{dia})$ & $37,5 \pm 1,7$ & $36,2 \pm 0,3$ & $37,4 \pm 2,6$ & $35,2 \pm 2,0$ \\
\hline
\end{tabular}


Para nos certificarmos que a via de administração e as doses utilizadas dos ácidos graxos não eram tóxicas aos animais, avaliamos as atividades das enzimas aspartato transaminase (AST), alanina transaminase (ALT) e lactato desidrogenase no soro dos animais tratados com OL e Li na dose mais elevada $(0,44 \mathrm{~g} / \mathrm{kg}$ de peso corporal). Ambos os tratamentos não alteraram os parâmetros analisados, evidenciando que não houve comprometimento hepático (Figura 2).
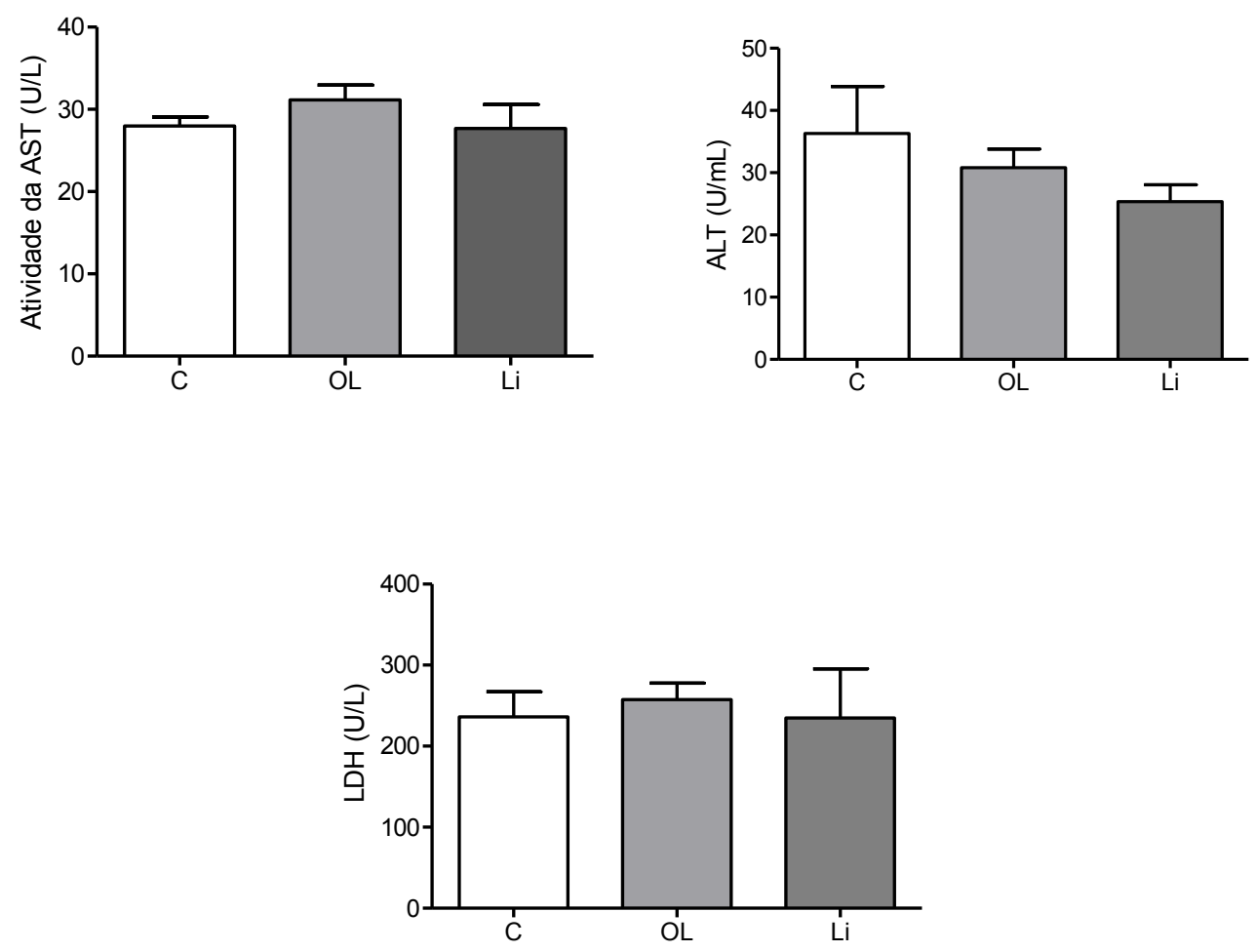

Figura 2. Atividade das enzimas séricas aspartato transaminase (AST), alanina transaminase (ALT) e lactato desidrogenase em animais controle (C) e suplementados com os ácidos oléico (OL) ou linoléico (Li) (dose $0,44 \mathrm{~g} / \mathrm{kg}$ de peso corporal) durante 10 dias. Os valores estão expressos como média \pm desvio-padrão da média de 5 animais por grupo. 
Para comprovarmos a inocuidade dos ácidos graxos sobre o trato gastrointestinal, realizamos estudos histológicos do intestino delgado desses mesmos animais. Avaliamos a relação vilosidade/cripta, número de linfócitos intraepiteliais, e número de células inflamatórias na lamina basal. Através desses parâmetros, verificamos que a via e a quantidade de ácidos graxos administrados não induziram toxicidade ao intestino delgado (Figura 3).

C

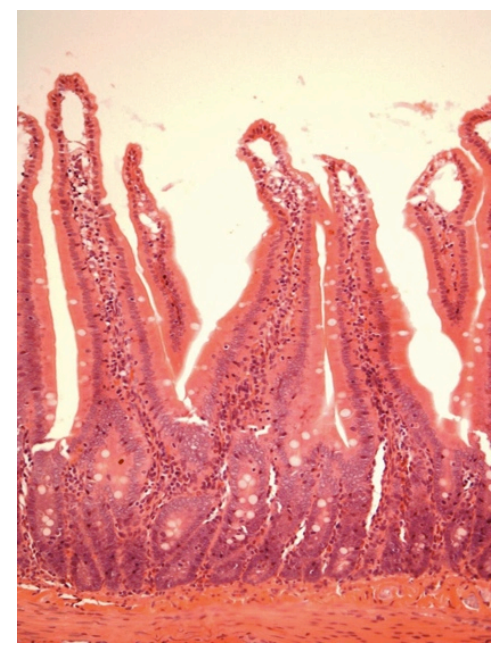

$\mathrm{OL}$

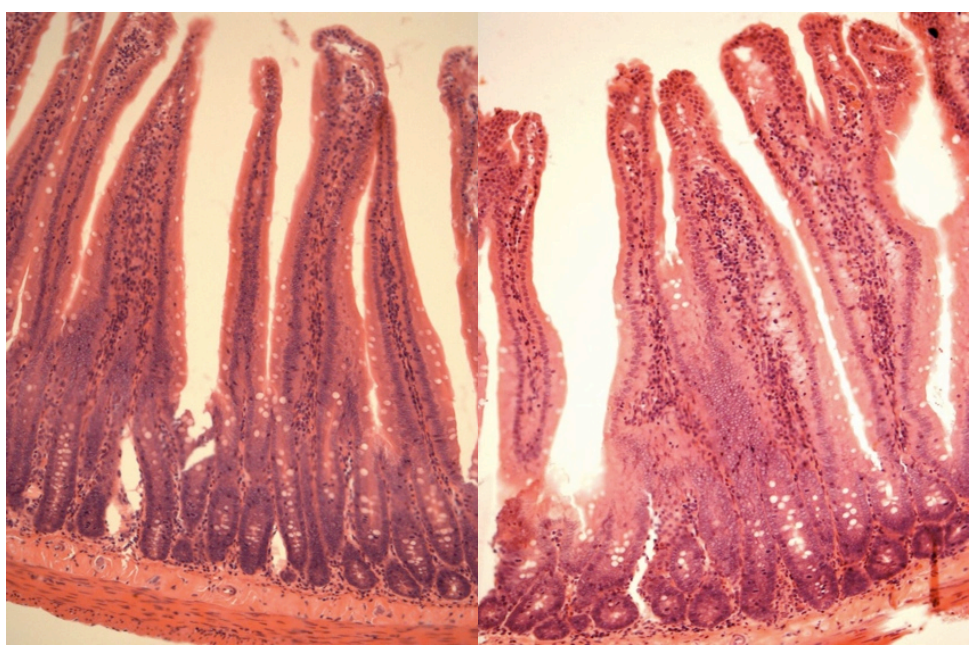

Figura 3. Fotomicrografias do intestino delgado de animais controle (C) e suplementados com os ácidos graxos oléico (OL) ou linoléico ( $\mathrm{Li}$ ) (dose de $0,44 \mathrm{~g} / \mathrm{kg}$ de peso corporal) durante 10 dias. Hematoxilina e eosina. 10X. 
A suplementação com os ácidos graxos foi iniciada 5 dias antes da indução das feridas e foi mantida até o fechamento das mesmas. Sete dias após a lesão, animais suplementados com $\mathrm{Li}$ apresentaram redução na área da ferida em comparação com os grupos C e OL (Figura 4). 

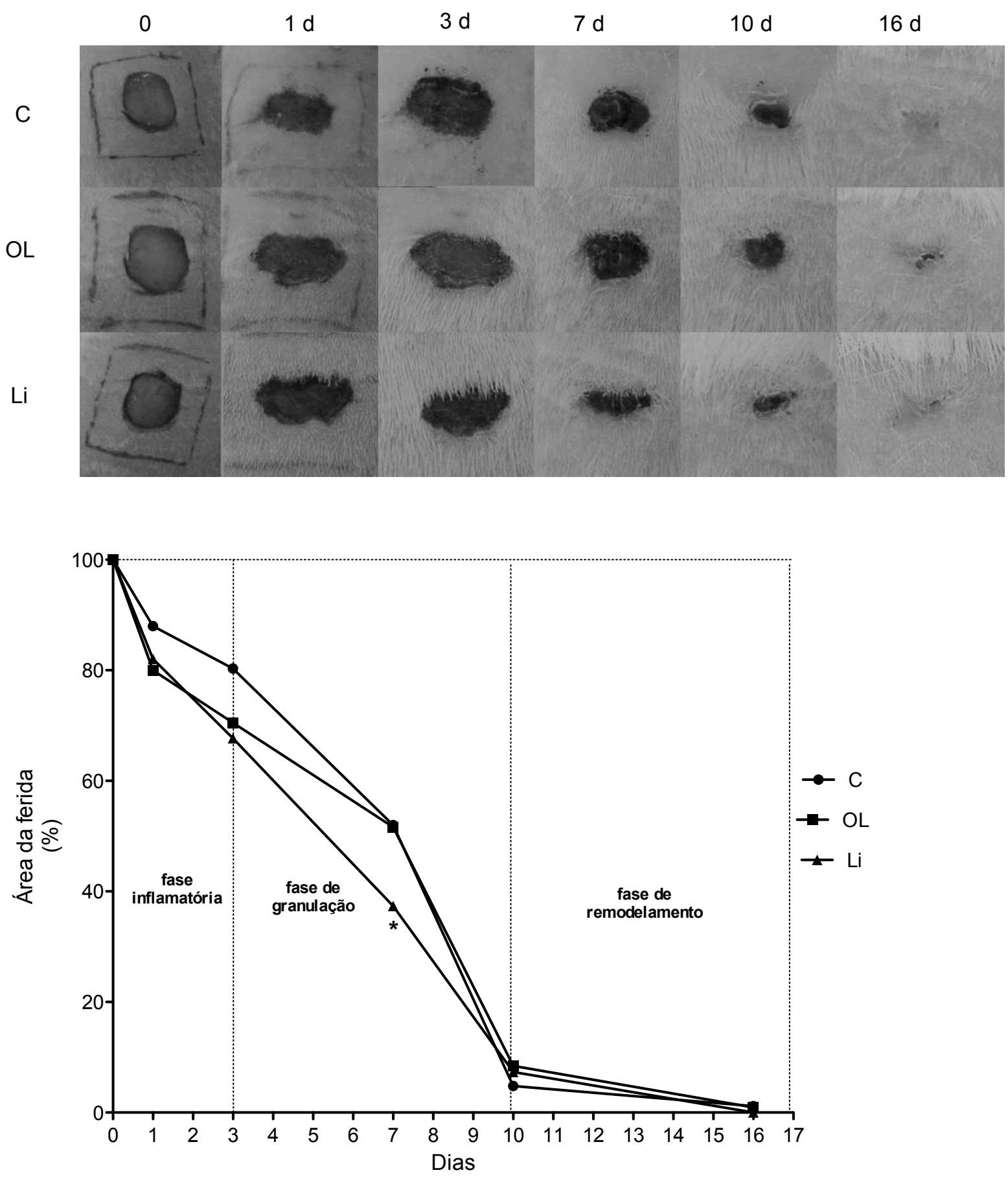

Figura 4. Fechamento da ferida de ratos controle (C) ou suplementados com os ácidos oleico $(\mathrm{OL})$ ou linoleico ( $\mathrm{Li})$. Fotos representativas de pelo menos 10 animais por grupo. Valores expressos como média \pm desvio-padrão da média. $\left(^{*}\right) p<0,05$ comparado ao controle, conforme indicado por One-way ANOVA e pós teste de Tukey 
Uma hora após a indução da ferida, o conteúdo de $\mathrm{H}_{2} \mathrm{O}_{2}$ foi elevado no grupo Li e, após 24 horas, retornou aos valores encontrados no grupo controle. No grupo OL não houve diferença no conteúdo de $\mathrm{H}_{2} \mathrm{O}_{2}$ na primeira hora após a ferida. Entretanto, em 24 horas, observamos redução na concentração de $\mathrm{H}_{2} \mathrm{O}_{2}$ em relação ao controle (Figura 5)

1 hora

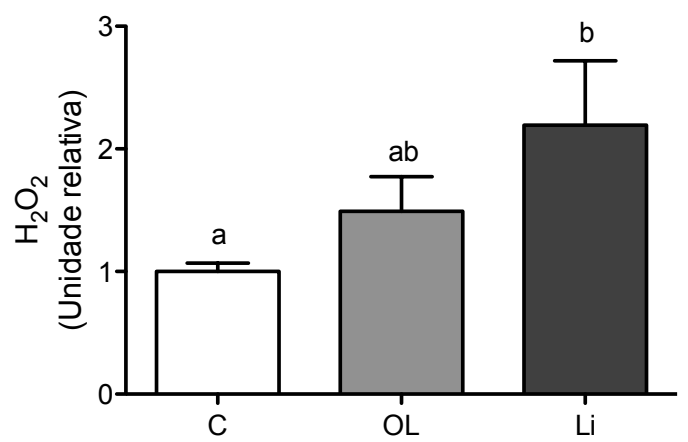

24 horas

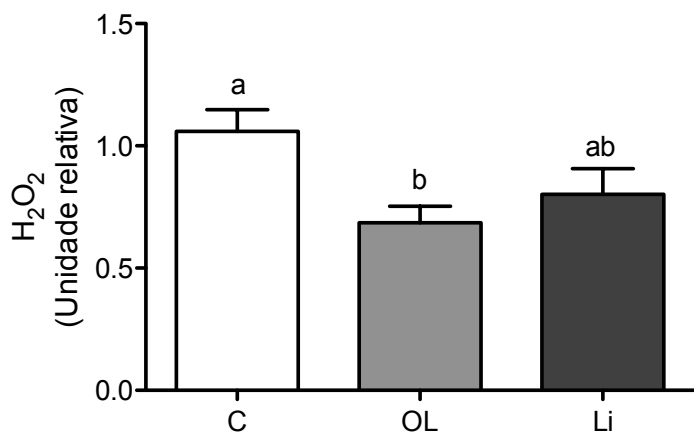

Figura 5. Conteúdo de peróxido de hidrogênio $\left(\mathrm{H}_{2} \mathrm{O}_{2}\right)$ no homogenato de feridas retiradas em diferentes períodos de tempo ( 1 e 24 horas) de animais controle (C) ou suplementados com os ácidos oleico (OL) ou linoleico ( $\mathrm{Li}$ ). Os valores estão expressos como média \pm erro-padrão da média de pelo menos 6 animais por grupo. Letras diferentes indicam diferenças significativas entre os grupos como indicado por one- way ANOVA e pós teste deTukey. 
A análise histológica das feridas demonstrou que uma hora após a lesão (Figura 6A-6C), poucas células inflamatórias foram observadas nos grupos $\mathrm{C}$ e OL. O grupo $\mathrm{Li}$, no entanto, mostrou aumento na infiltração de células inflamatórias, especialmente em torno da microvasculatura. Após 24 do ferimento (Figura 6D-6F), o tecido conjuntivo foi infiltrado por muitas células inflamatórias, principalmente neutrófilos, e uma massa superficial espessa, constituída de coágulo, tecido morto e células inflamatórias foi observada em todos os grupos. O infiltrado inflamatório sob essa massa era visivelmente menor no grupo Li em relação aos demais (Figura 6).

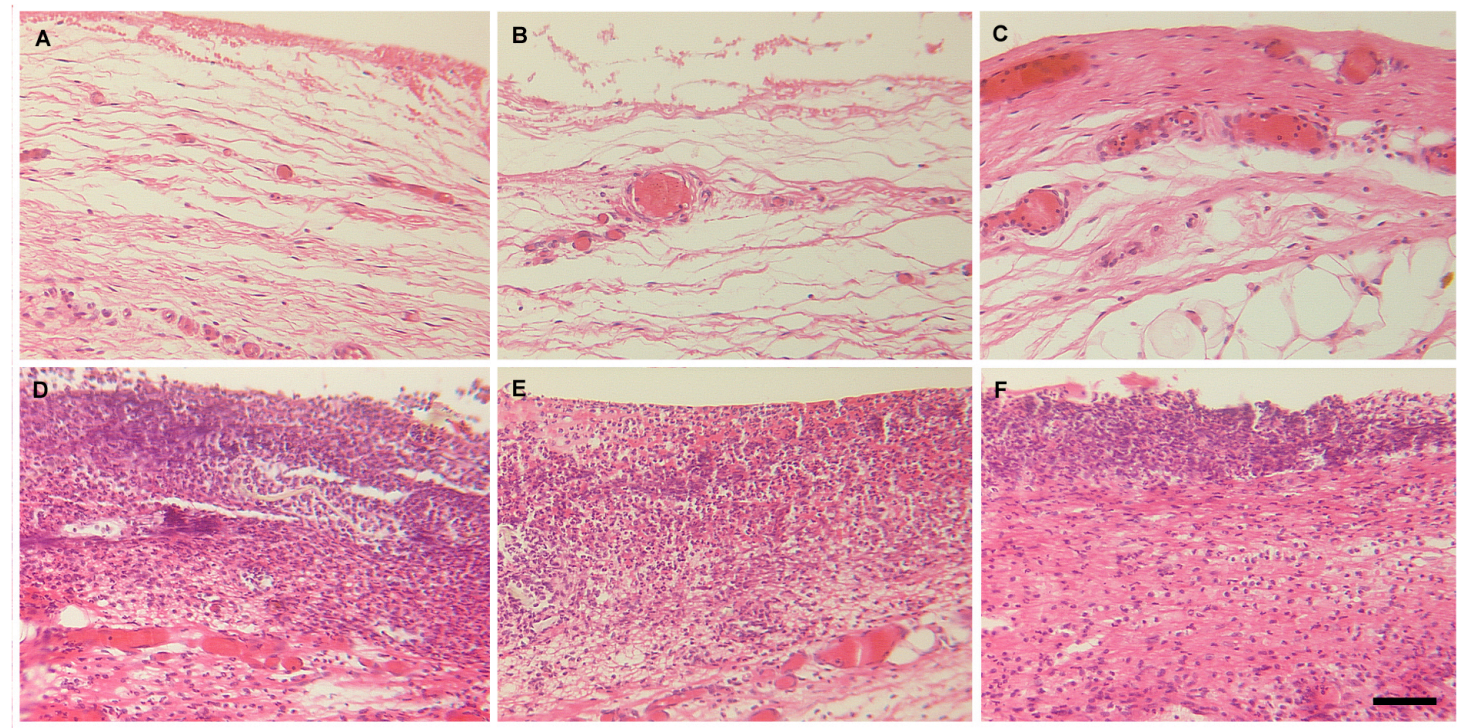

Figura 6. Morfologia das feridas após $1(A, B, C)$ e 24 horas $(D, E, F)$ em ratos controle $(A$, D) ou suplementados diariamente com acido oleico $(B, E)$ ou linoleico $(C, F) .100$ $\mu \mathrm{m}$. 
Em seguida, analisamos a ativação do fator de transcrição NF-KB nestes tecidos. Apenas a suplementação com OL induziu ativação do NF-kB uma hora após a indução da ferida (Figura 7a). Por outro lado, 24 horas após o ferimento, a suplementação com ambos ácidos graxos reduziu a ativação desse fator de transcrição (Figura 7b).
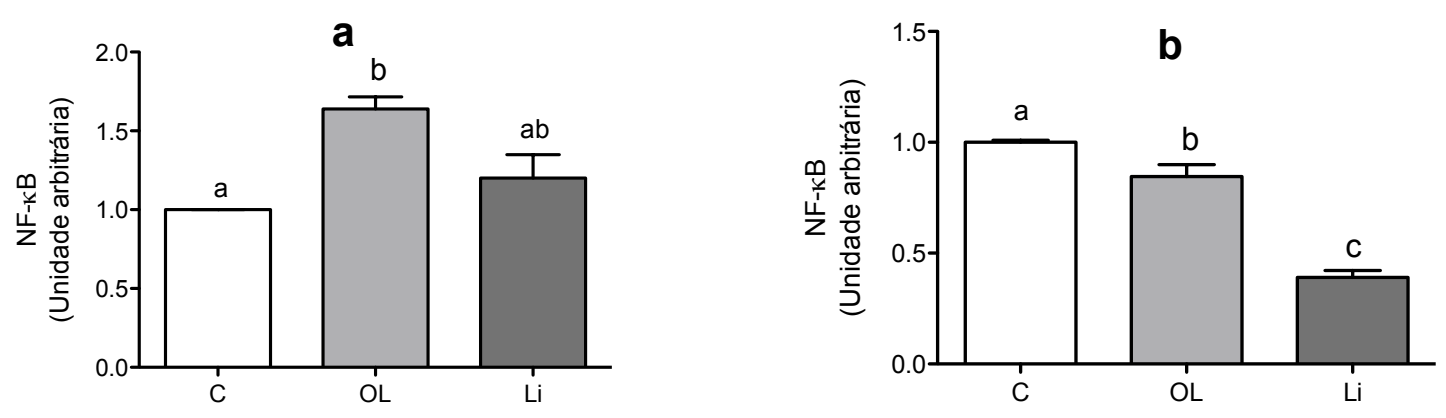

Figura 7. Ativação do fator de transcrição NF-kB em tecidos cicatriciais retirados após 1 (a) e 24 (b) horas da indução das feridas em animais controles (C) e suplementados com os ácidos oleico $(\mathrm{OL})$ ou linoleico $(\mathrm{Li})$. Os valores estão apresentados como média \pm erro-padrão da média de 5 animais por grupo. Letras diferentes indicam diferenças significativas entre os grupos, como indicado por ANOVA e pós teste deTukey. 
A suplementação com o ácido linoleico causou a ativação do fator de transcrição AP-1 nos tecidos coletados 1 hora após a ferida. Entretanto, em 24 horas, não houve diferença entre os grupos (Figura 8).
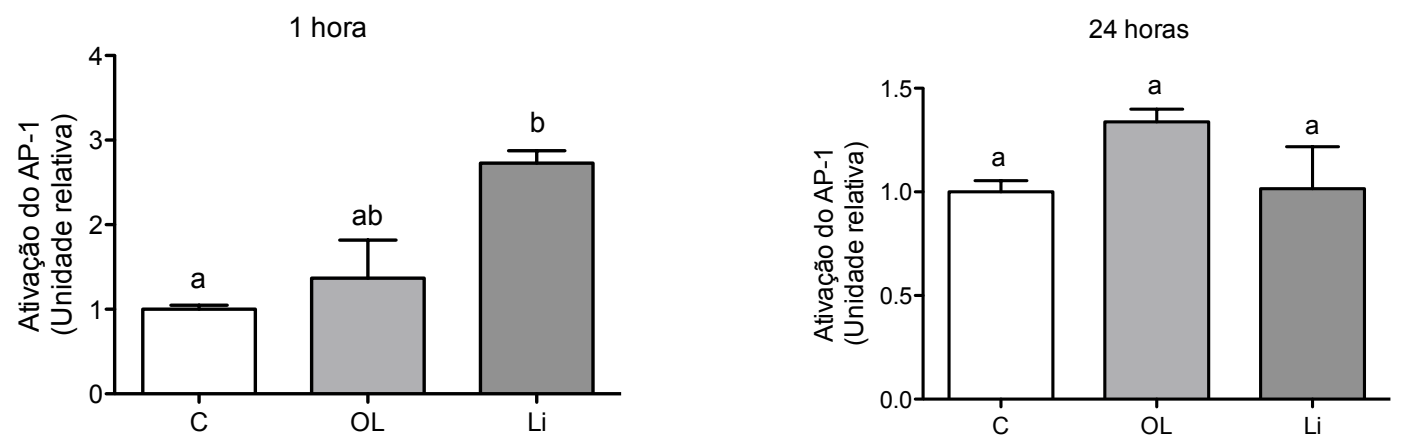

Figura 8. Ativação do fator de transcrição AP-1 em tecidos cicatriciais retirados após 1 e 24 horas da indução das feridas em animais controles (C) e suplementados com os ácidos oleico $(\mathrm{OL})$ ou linoleico $(\mathrm{Li})$. Os valores estão apresentados como média \pm erro-padrão da média de 8 animais por grupo. Letras diferentes indicam diferenças significativas entre os grupos, como indicado por ANOVA e pós teste de Tukey. 
Considerando que a ativação de fatores de transcrição como o NF- kB e o AP-1 está relacionada com a produção de citocinas inflamatórias e fatores de crescimento, investigamos as concentrações das citocinas no homogenato das feridas retiradas de animais controle ou tratados com OL ou Li. No grupo controle, as concentrações máximas de CINC-2 $\alpha \beta$ e IL-1 $1 \beta$ foram alcançadas 24 horas após a indução da ferida. Em 120 horas após a ferida, as concentrações de CINC-2 $\alpha \beta$ e IL$1 \beta$ já não diferiram do tempo Oh (Figuras 9a e 9c). OL e Li aumentaram as concentrações de TNF- $\alpha$ e CINC-2 $\alpha \beta$, respectivamente, nos tecidos retirados uma hora após a indução da ferida (Figuras 9a e 9b). Vinte e quatro horas após a cirurgia, outras citocinas, como IL-1 $\beta$, IL- 6 e MIP-3a, tiveram as concentrações reduzidas nos animais suplementados com os ácidos oleico ou linoleico (Figuras $9 \mathrm{c}$ - 9e). Não houve diferença significativa nas concentrações das citocinas 120 horas após a indução da ferida (Figuras 9a-9e). 
a
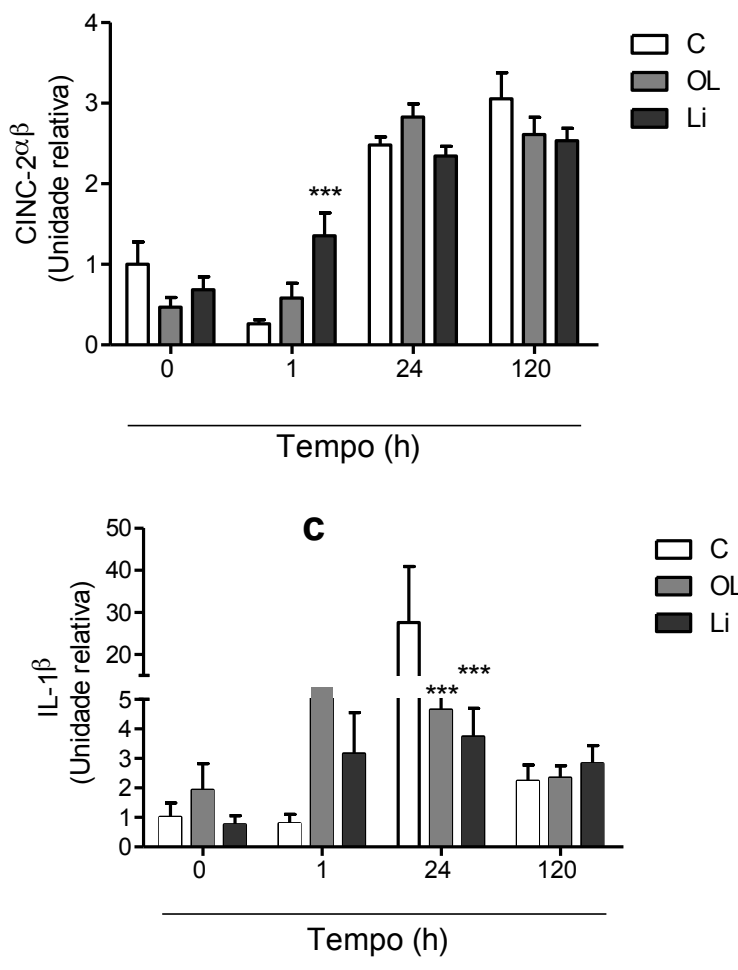

b

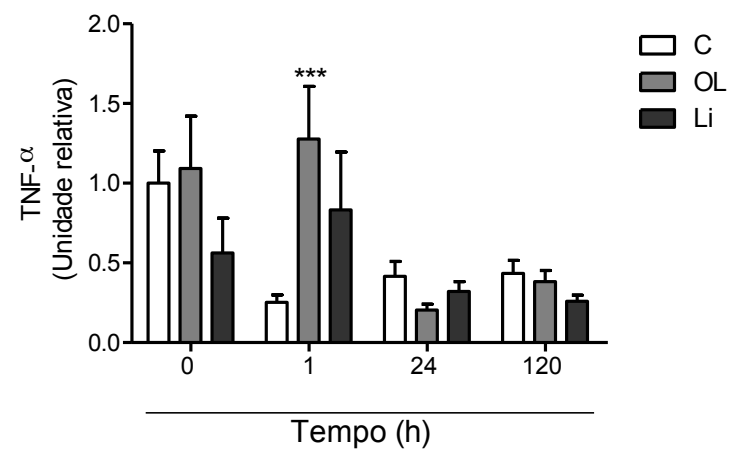

d

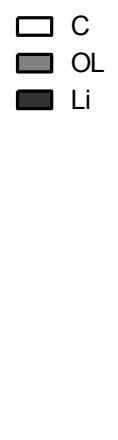

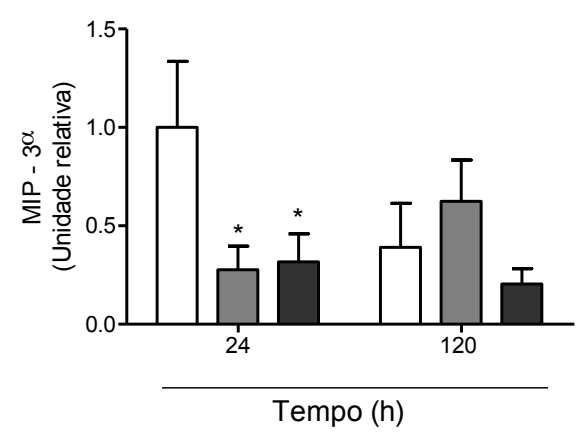

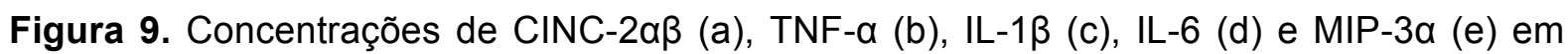
feridas de animais controles $(C)$ e tratados com os ácidos oleico $(\mathrm{OL})$ ou linoleico (Li) e analisadas em diferentes períodos (0, 1, 24 e 120 horas). Os valores estão apresentados como média \pm erro padrão da média de pelo menos 5 animais por grupo. $\left(^{*}\right) p<0.05,\left(^{* * *}\right) p<0.001$ para diferenças significativas em relação ao $C$ como indicado por ANOVA e pós teste de Dunnett. 
A análise da expressão (RNAm) das citocinas confirmou os resultados obtidos no ELISA e ainda mostrou diferenças entre os $A G$ que não foram detectadas anteriormente. OL aumentou a expressão de CINC-2, IL-1, IL-6 e TNF- $\alpha$ uma hora após o ferimento em relação ao grupo controle. Em 24 horas, a expressão de CINC2 ainda estava maior no grupo $\mathrm{OL}$, mas IL-1 e IL-6 já estavam reduzidas. A suplementação com Li aumentou a expressão de CINC-2 e não alterou a expressão das demais citocinas. Vinte e quatro horas após o ferimento, a expressão de CINC, IL-1 e IL-6 foi reduzida no grupo Li. Quando comparados os grupos OL e Li observamos que o primeiro foi mais pró-inflamatório pois a expressão de CINC-2, IL-1, IL-6 e TNF- $\alpha$ foi elevada em 24 horas.

CINC-2
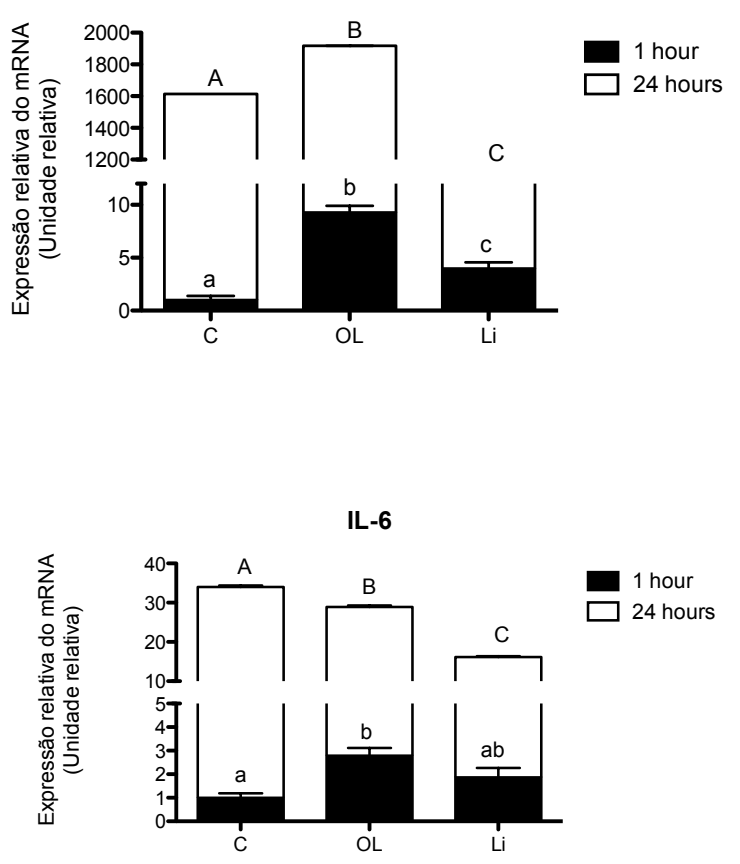

IL-1
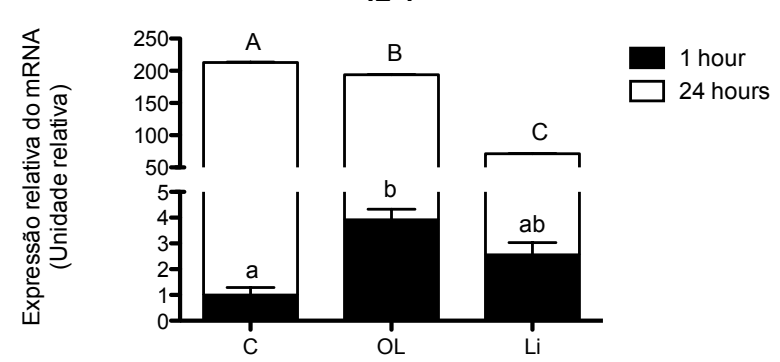

TNF- $\alpha$
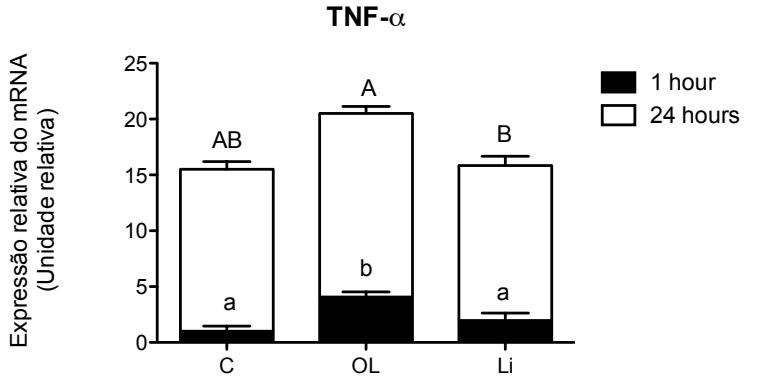

Figura 10. Expressão relativa do mRNA das citocinas CINC 2, IL-1 $\beta$, IL-6 e TNF- $\alpha$ em feridas de animais controles $(C)$ e tratados com os ácidos oleico (OL) ou linoleico ( $\mathrm{Li}$ ) e analisadas 1 e 24 horas após a indução da ferida. Os valores estão apresentados como média \pm erro padrão da média de pelo menos 6 animais por grupo. Letras minúsculas diferentes indicam diferenças significativas entre os grupos em relação ao período 1 hora. Letras maiúsculas diferentes indicam diferenças significativas entre os grupos em relação ao período 24 horas como indicado por ANOVA e pós teste de Tukey. 
Em resumo, um dos primeiros eventos que ocorrem após a lesão é a hipóxia devido ao rompimento dos vasos dificultando assim a oxigenação dos tecidos. As EROs geradas são importantes não só para desinfetar o local da ferida, mas também podem atuar como mensageiros de sinalização celular e assim regular a ativação de fatores de transcrição, o recrutamento de células inflamatórias e a produção de citocinas. Como observado, a produção de $\mathrm{H}_{2} \mathrm{O}_{2}$ é modulada pela ingestão de Li uma hora após a lesão. $\mathrm{O}$ aumento no conteúdo de $\mathrm{H}_{2} \mathrm{O}_{2}$ pode estar envolvido na ativação do AP-1, aumentando a expressão de citocinas inflamatórias e fatores de crescimento. $\mathrm{O}$ aumento na atividade do AP-1 também está relacionado com a proliferação de queratinócitos e fibroblastos, importantes para a próxima fase, formação do tecido de granulação. Por outro lado, no grupo $\mathrm{OL}$ o conteúdo de $\mathrm{H}_{2} \mathrm{O}_{2}$ não foi alterado na primeira hora após o ferimento, assim como o recrutamento de células inflamatórias e a atividade do AP-1 pareceram ser semelhantes ao observado no controle. Juntos, estes resultados sugerem um efeito direto do OL na ativação do NF-kB com consequente aumento na produção de citocinas próinflamatórias, sem a participação do $\mathrm{H}_{2} \mathrm{O}_{2}$. 


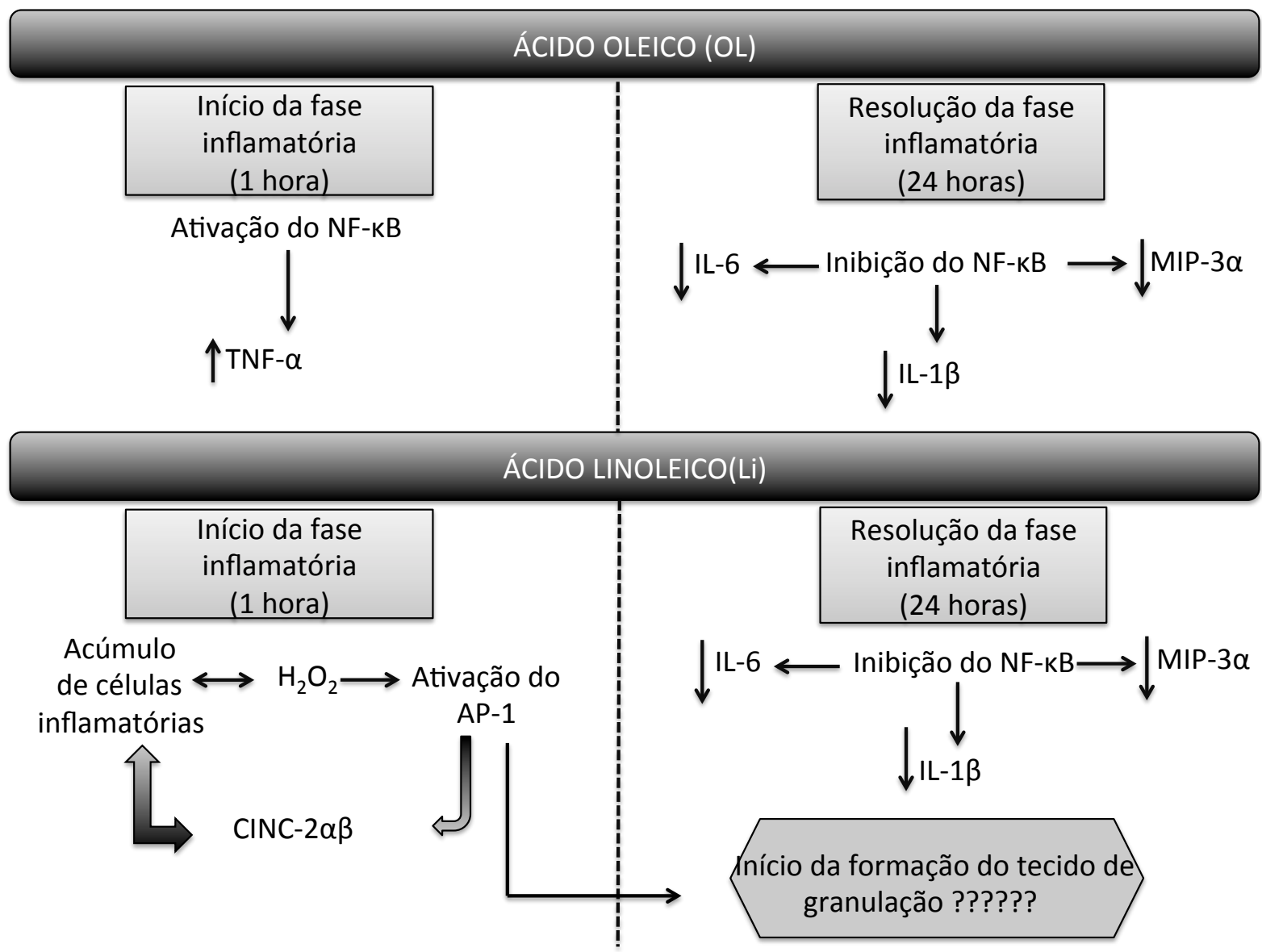

Figura 11. Esquema dos efeitos da administração dos ácidos oleico (OL) e linoleico (Li) sobre o processo de cicatrização. 
Considerando os efeitos da administração de OL e Li no processo de cicatrização, investigamos se a ingestão desses ácidos graxos pode modular funções de neutrófilos, as primeiras células que migram para o local inflamado.

Como demonstrado anteriormente, os ácidos graxos podem induzir morte celular (CURY-BOAVENTURA et al., 2005). Assim, avaliamos dois parâmetros indicativos desse processo em neutrófilos isolados de animais suplementados com $\mathrm{OL}$ ou Li. Não foram observadas alterações na fragmentação do DNA e na porcentagem de neutrófilos viáveis (Figura 12). Desta forma, as alterações observadas nas funções dos neutrófilos não foram devidas à toxicidade dos ácidos graxos. 

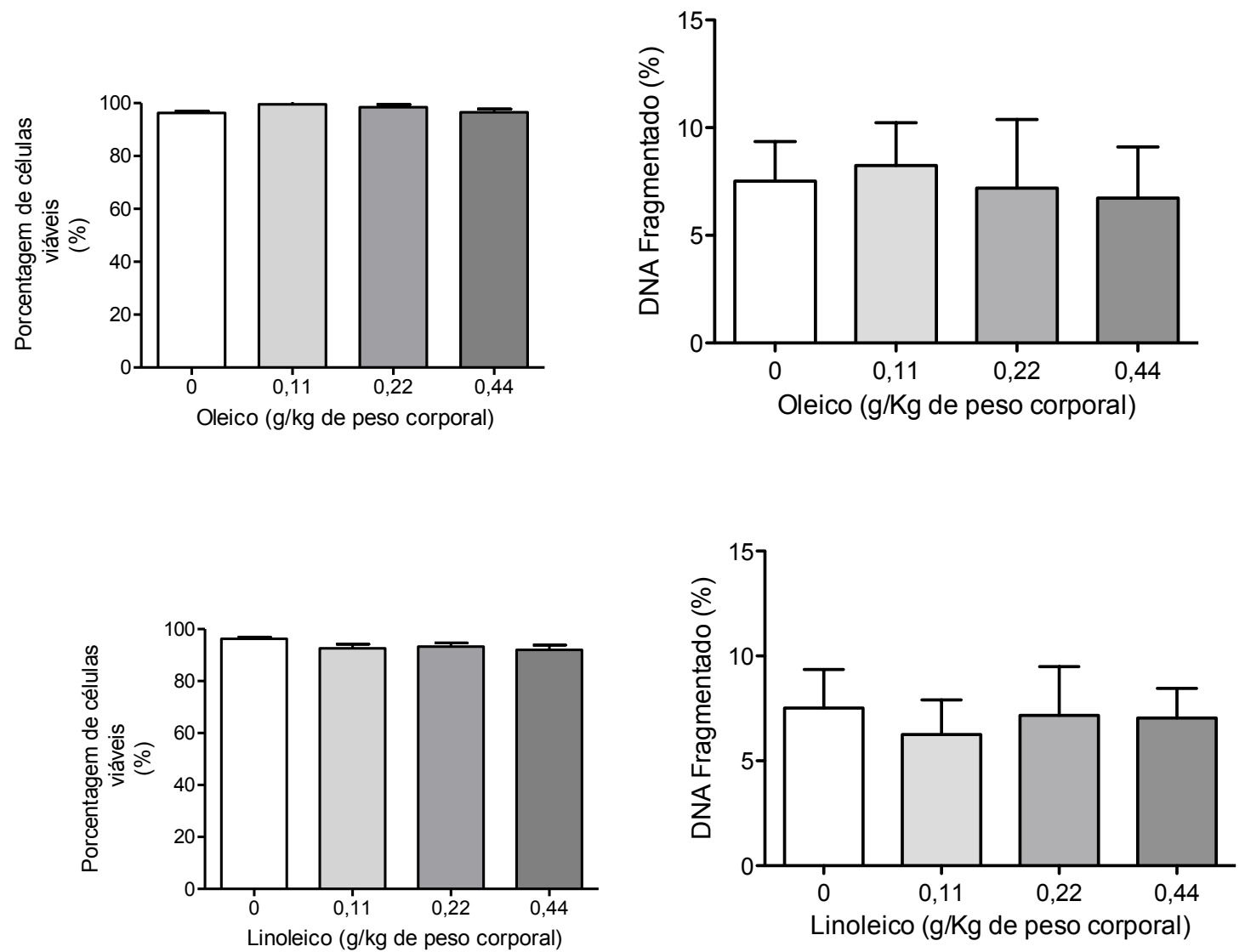

Figura 12. Viabilidade e fragmentação de DNA de neutrófilos isolados de ratos suplementados com os ácidos oléico ou linoléico. Os valores estão representados como média \pm erro-padrão da média de 7 animais por grupo. 
A migração de neutrófilos para o local lesionado é importante para o início da resposta inflamatória. Uma vez no local, neutrófilos liberam mediadores próinflamatórios como citocinas, espécies reativas de oxigênio e enzimas para atrair mais células e destruir o agente causador da injúria. Em nosso estudo, a suplementação com os ácidos oleico e linoleico aumentou a migração de neutrófilos para o peritônio (Figura 13).

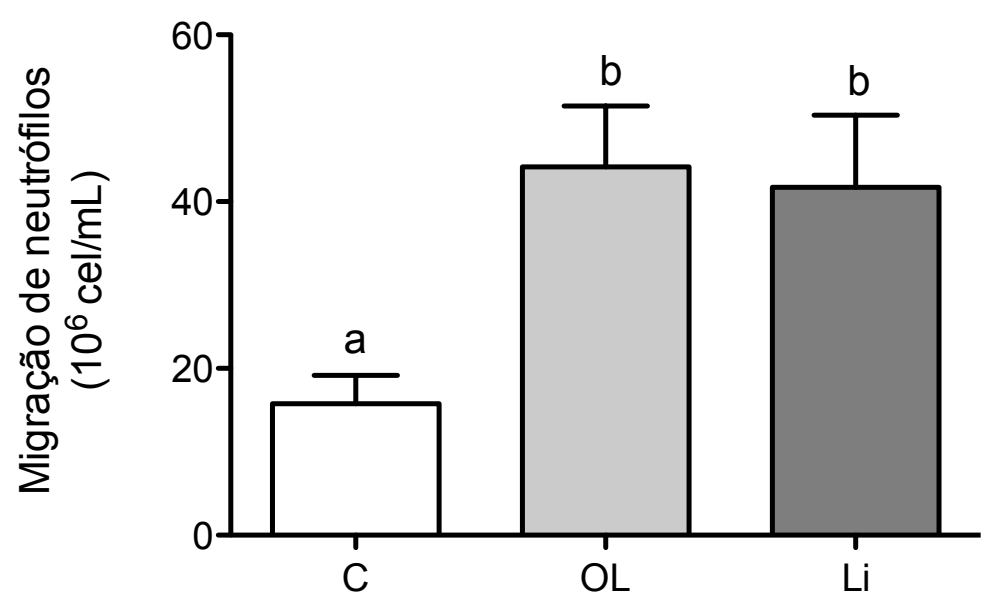

Figura 13. Influxo de neutrófilos para a cavidade peritoneal, induzido por solução de glicogênio $(1 \%)$, em ratos controle suplementados com os ácidos oleico ou linoleico. Resultados expressos como média \pm erro-padrão da média de pelo menos 8 animais por grupo. Letras diferentes indicam diferenças significativas entre os grupos, como indicado por ANOVA e pelo pós-teste de Tukey. 
A migração de leucócitos para o sítio inflamatório envolve, entre outros fatores, a expressão de moléculas de adesão. Investigamos se o aumento na migração de neutrófilos era decorrente da maior expressão de L-selectina e $\beta 2$ integrina. Ambos os ácidos graxos elevaram a expressão de L-selectina, mas não houve alteração na expressão de $\beta 2$-integrina em neutrófilos não estimulados (Figura 14). Os tratamentos não modificaram a expressão destas moléculas de adesão em neutrófilos estimulados com fMLP (dados não apresentados).
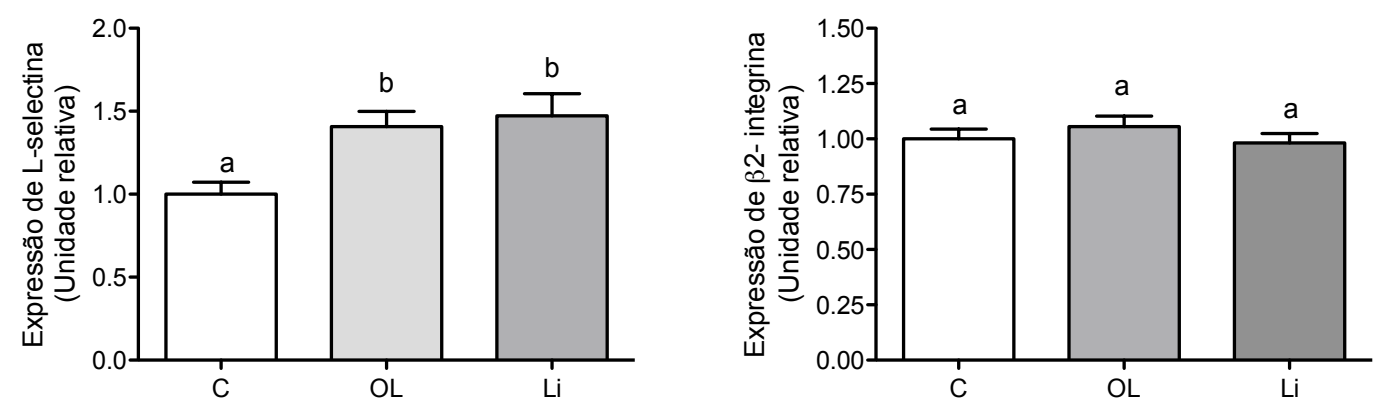

Figura 14. Expressão de L-selectina e $\beta 2$-integrina em neutrófilos isolados da aorta abdominal de ratos controle (C) ou suplementados $(0,22 \mathrm{~g} / \mathrm{kg}$ de peso corporal) com ácidos oleico (OL) ou linoleico (Li). Os valores estão apresentados como média \pm erro-padrão da média de pelo menos 6 animais por grupo. Letras diferentes indicam diferenças significativas entre os grupos, como indicado por ANOVA e pós-teste de Tukey. 
Através de análises in vivo da interação dos leucócitos com o endotélio, confirmamos que a ingestão de OL e Li resulta em aumento no rolling e no número de leucócitos aderidos ao endotélio, na ausência de estímulo (basal) (Figura 15). Após a aplicação tópica do fMLP, houve elevação no rolling e na aderência ao endotélio. Nestas condições, apenas o Li manteve elevada a interação dos leucócitos/endotélio (Figura 15).
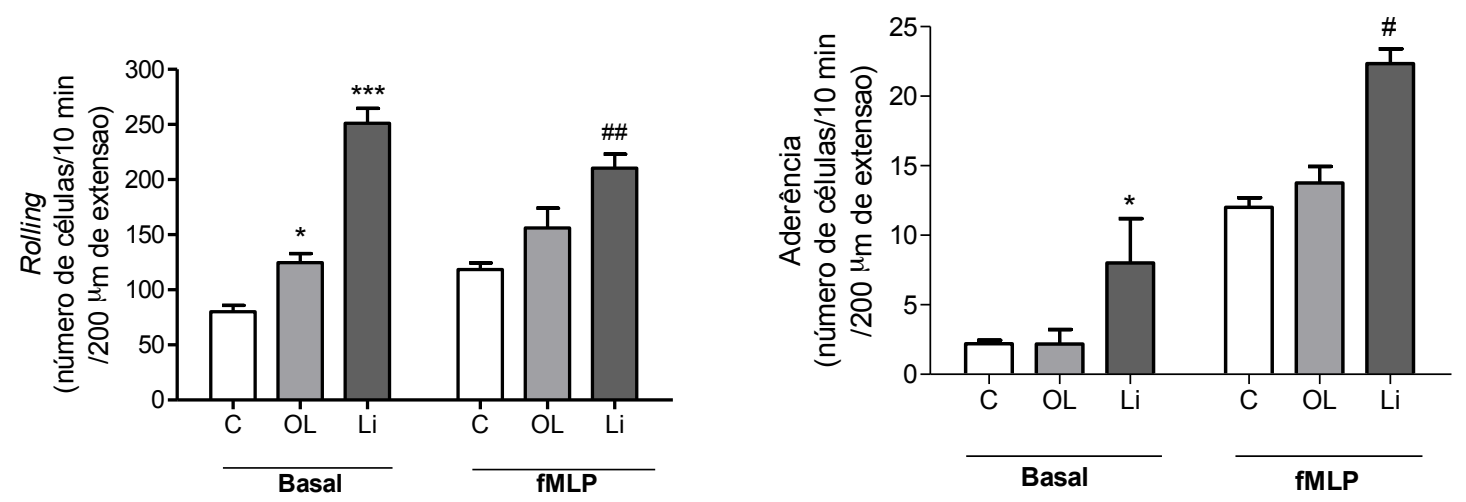

Figura 15. Rolling e aderência de neutrófilos em ratos controle (C) ou suplementados com $(0,22 \mathrm{~g} / \mathrm{kg}$ de peso corporal) os ácidos oléico $(\mathrm{OL})$ ou linoléico $(\mathrm{Li})$. Os valores estão apresentados como média \pm erro-padrão média de 3 animais por grupo através da análise de pelo menos 3 campos por animal. $\left(^{*}\right) p<0,05$ e $\left(^{* *}\right)$ $p<0,001$ para diferenças significativas em relação ao grupo $C ;(\#) p<0,05$ e (\#\#) $p<0,01$ para diferenças significativas em relação ao grupo $C$ estimulado topicamente com fMLP (10 nM), como indicado por ANOVA e pós-teste de Tukey. 
Outra maneira de analisarmos a influência dos ácidos graxos sobre a resposta migratória de neutrófilos é através do modelo de bolsa de ar. Novamente observamos que o aumento no número de células no exsudato da bolsa de ar, induzido pelos ácidos OL e Li, foi significativo na condição basal (sem fMLP) (Figura 16a) e pode estar relacionado com a concentração elevada da quimiocina CINC$2 \alpha \beta$ (Figura 16b).
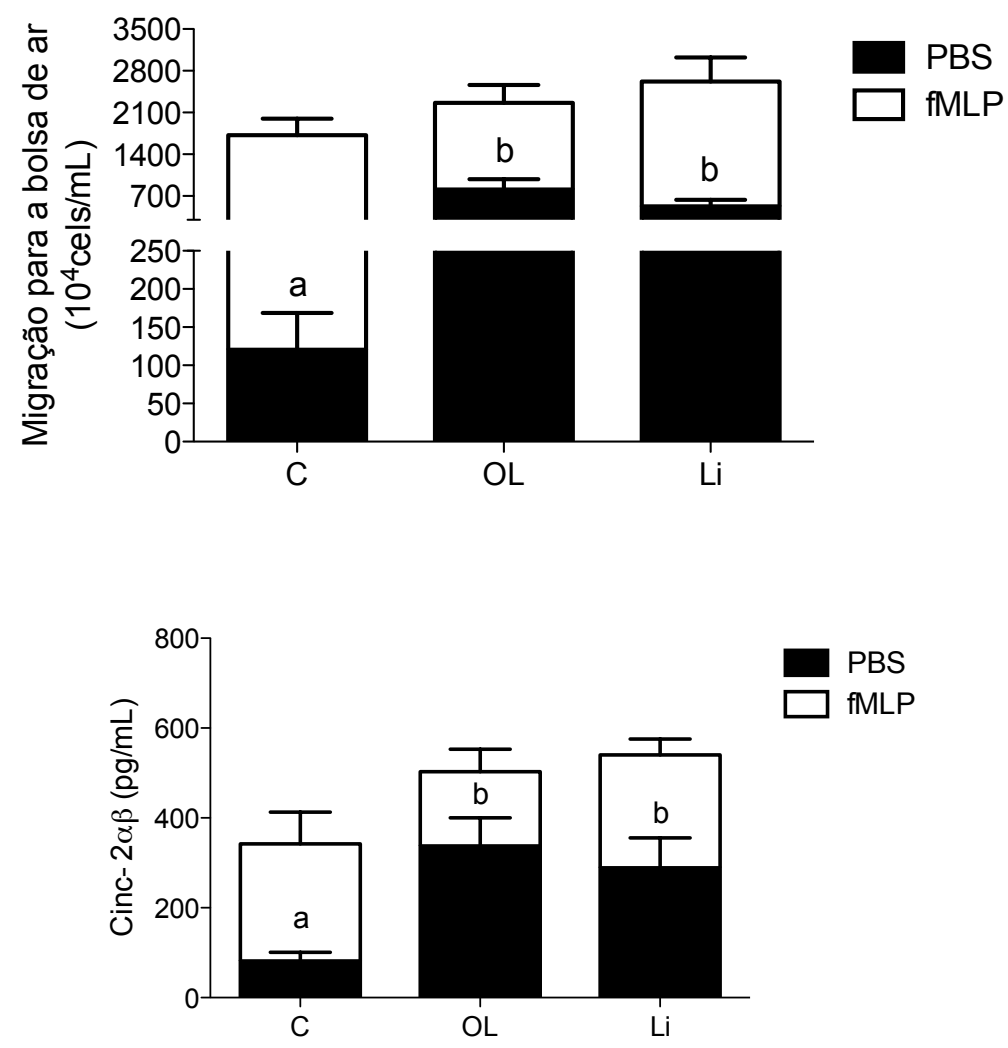

Figura 16. Influxo de neutrófilos (a) e concentração de CINC-2aß (b) no exsudato inflamatório da bolsa de ar induzida em ratos controle (C) ou suplementados com os ácidos oléico $(\mathrm{OL})$ ou linoléico (Li). Os valores apresentados como média \pm erro-padrão da média de 6 animais por grupo. Letras diferentes indicam diferenças significativas entre os grupos na condição basal (PBS), como indicado por ANOVA e pós-teste de Tukey. Foi injetado $1 \mathrm{~mL}$ de solução de fMLP (10 nM) como estímulo. 
A influência da ingestão de $\mathrm{OL}$ e Li na produção ex vivo de citocinas por neutrófilos também foi avaliada. As concentrações de CINC-2 $\alpha \beta$ e IL-1 $1 \beta$ foram determinadas no sobrenadante de neutrófilos incubados durante 4 e 18 horas, na presença e na ausência de estímulo (LPS). Apesar da correlação positiva entre a ingestão de $\mathrm{OL}$ (todas as doses) e a produção de CINC-2 $\alpha \beta\left(r^{2}=0,92\right.$ correlação de Pearson, $p<0,02)$ e IL-1 $\beta\left(r^{2}=0,92\right.$ correlação de Pearson, $\left.p<0,001\right)$ na ausência do estímulo, não houve diferença significativa em relação ao grupo controle (Figuras 17 a e 17c). A suplementação com Li elevou as concentrações de CINC-2 $\alpha \beta$ e IL-1 $\beta$ de modo dose-dependente $\left(r^{2}=0,93\right.$ e 0,98 , respectivamente; $p<0,01$ e $p<0,003$, respectivamente). Este efeito foi significativo para a dose de $0,44 \mathrm{~g} / \mathrm{kg}$ de peso corporal (Figuras 17b e 17d). Após o estímulo com LPS, o OL não alterou a produção das citocinas analisadas, entretanto, Li (dose de $0,44 \mathrm{~g} / \mathrm{kg}$ de peso corporal) reduziu as concentrações de CINC-2aß (Figura 17b). 


\section{HORAS}

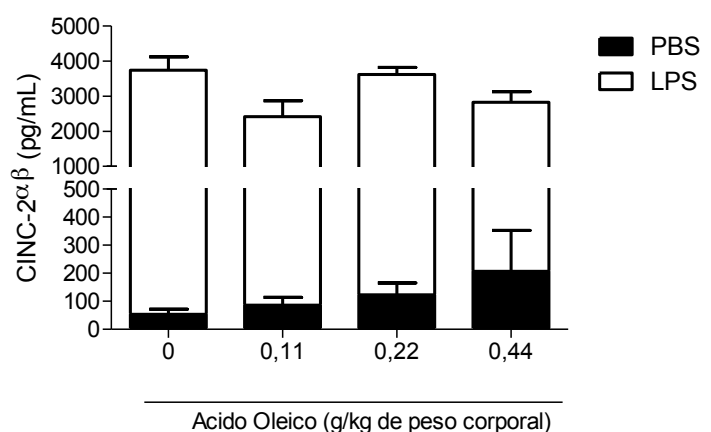

C

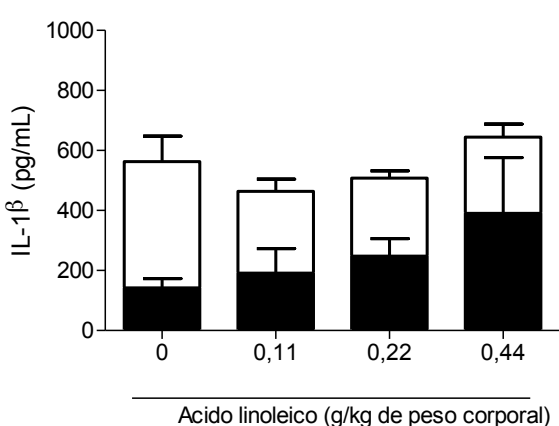

b

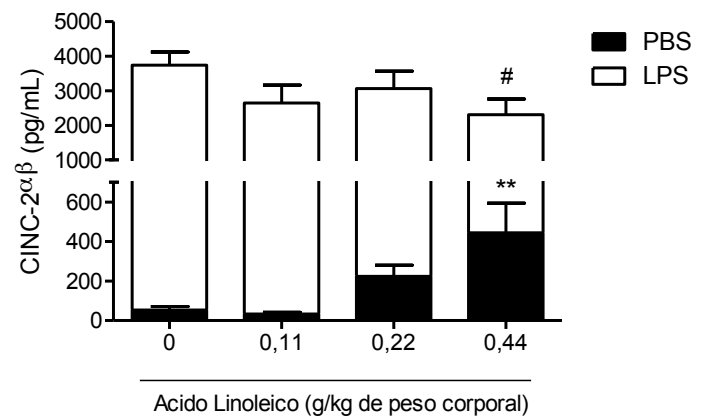

d

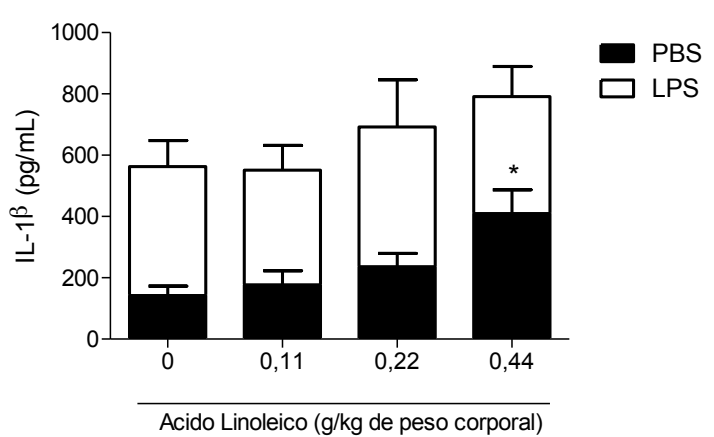

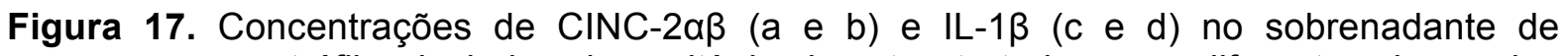
neutrófilos isolados do peritônio de ratos tratados com diferentes doses dos ácidos oléico ou linoléico. Neutrófilos foram incubados durante 4 horas na ausência (PBS) ou presença do estímulo (LPS $-5 \mu \mathrm{g} / \mathrm{mL}$ ). Os valores estão apresentados como média \pm erro-padrão da média de pelo menos 6 animais por grupo. $\left(^{*}\right) p<0,05$ e $\left(^{* *}\right) p<0,001$ para diferenças significativas em relação á condição basal (PBS); (\#) $p<0,05$ para diferença significativa em relação a condição estimulada (LPS), como indicado por ANOVA e pós teste de Dunnett. 
Após 18 horas de incubação, ambos ácidos graxos diminuíram a produção de CINC-2 $\alpha \beta$ e IL-1 $\beta$ na condição basal (PBS) (Figuras 18a - 18d). Em neutrófilos estimulados com LPS, a administração de OL (todas as doses) reduziu a produção de IL-1 $\beta$, mas não alterou as concentrações de CINC-2 $\alpha \beta$ (Figuras 18a e 18c).

\section{HORAS}
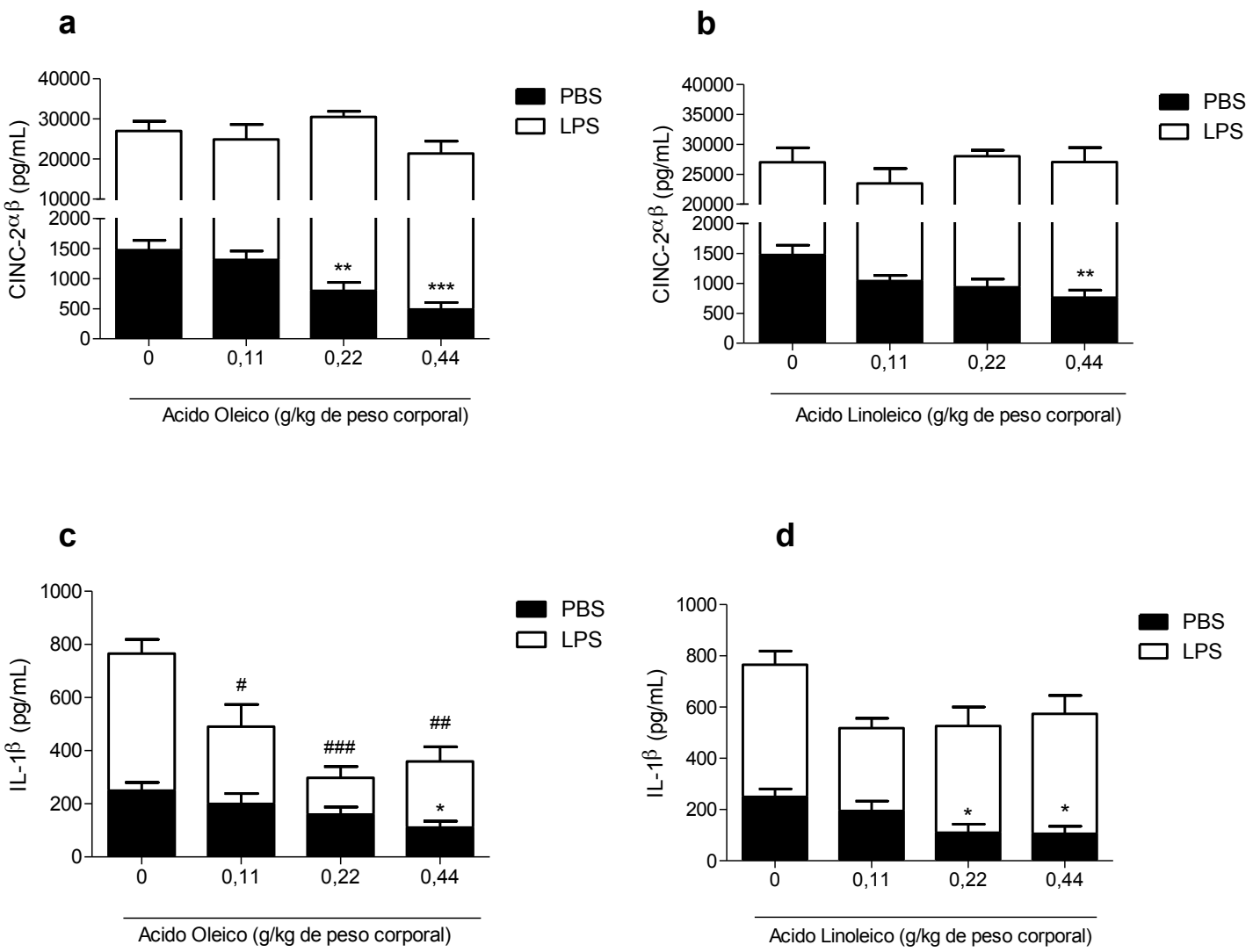

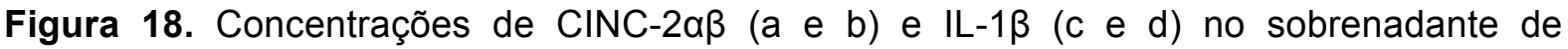
neutrófilos isolados do peritônio de ratos suplementados com diferentes doses dos ácidos oléico ou linoléico. Neutrófilos foram incubados durante 18 horas na ausência (PBS) ou presença do estímulo (LPS- $5 \mu \mathrm{g} / \mathrm{mL}$ ). Os valores estão apresentados como média \pm erro-padrão da média de pelo menos 6 animais por grupo. $\left(^{*}\right) p<0,05$ e $\left(^{* *}\right), p<0,01\left(^{* * *}\right) p<0,001$ para diferenças significativas em relação à condição basal (PBS); (\#) $p<0,05$, (\#\#) $p<0,01$ e (\#\#\#)p<0,001 para diferenças significativas em relação a condição estimulada (LPS), como indicado por ANOVA e pós-teste de Dunnett. 


\section{DISCUSSÃO}

O modo mais comum de administração dos ácidos graxos, em humanos ou animais de experimentação, é através do uso de óleos (triacilgliceróis) ricos em determinado ácido graxo ou de emulsões lipídicas ricas no ácido graxo de interesse. Através desses modelos, entretanto, não podemos garantir que o efeito foi devido a um determinado ácido graxo ou a combinação deles. Desta forma, a administração oral de ácidos graxos puros tem como vantagem não haver a interferência de outros nutrientes (RODRIGUES et al., 2010 ; VIDGREN et al., 1997; SURESH e DAS, 2003; FAINE et al., 2006).

As atividades séricas das enzimas AST, ALT e LDH são utilizadas como marcadores clínicos de danos hepáticos (AMACHER, 1998; CHO et al., 2008). Essas enzimas são liberadas para a corrente sanguínea quando os hepatócitos sofrem alguma injúria, aumentando assim, suas atividades séricas. Como observado no presente estudo, a administração de OL e Li não alterou as atividades séricas dessas enzimas (Figura 2), indicando que tanto a dose quanto a via de administração não induziram danos ao fígado dos animais. As análises histológicas do intestino delgado também não mostraram alterações decorrentes da suplementação dos ácidos graxos (Figura 3). Fujiyama et al. (2007) administraram $100 \mu \mathrm{L}$ dos ácidos OL e $\mathrm{Li}$ diretamente no duodeno de camundongos e não relataram efeito tóxico dos ácidos graxos. Com base em nossos resultados, confirmamos que a metodologia utilizada para administração dos ácidos graxos não foi tóxica e não prejudicou o estado geral dos animais.

O processo de cicatrização ou reparo tecidual ocorre em todos os tecidos após exposição a qualquer estímulo injuriante. Assim, a sequência de eventos que ocorre depois de um infarto do miocárdio, por exemplo, é similar ao que acontece após algum dano na medula espinhal ou em uma queimadura de pele (GURTNER et al., 2008). O objetivo destes eventos reparadores é impedir a invasão por patógenos e restabelecer a integridade dos tecidos danificados, reconstruindo assim sua função (SINGER e CLARK, 1999). 
O uso tópico dos ácidos graxos no tratamento de feridas é uma prática comum nos países em desenvolvimento, como o Brasil, apesar do escasso conhecimento científico (PIEPER e CALIRI, 2003). Os primeiros estudos envolvendo lipídios e feridas indicavam que os efeitos das gorduras sobre a cicatrização eram decorrentes das suas propriedades físico-químicas, ou seja, elas atuam como uma barreira impermeável impedindo assim a perda de água para o meio e a entrada de microrganismos (DECLAIR, 1997). Em estudos subsequentes foi demonstrado que a aplicação tópica de óleos ou ácidos graxos estimula a produção de fibras no tecido conectivo (CARDOSO et al., 2004), reduz a espessura da camada de células necróticas (PEREIRA et al., 2008) e ainda acelera o fechamento das feridas (OTRANTO et al., 2010 ; PARK et al., 2010).

O ácido linoleico é o principal ácido graxo presente na epiderme (MCCUSKER e GRANT-KELS, 2010) e é responsável pela manutenção da permeabilidade do estrato córneo, bem como da maturação e diferenciação desta camada. Considerando que a incorporação dos ácidos graxos na pele é modulada pela ingestão na dieta, e que os ácidos oleico e o linoleico são os mais consumidos (US DEPARTMENT OF AGRICULTURE, 2008) investigamos os efeitos do consumo desses no processo de cicatrização em ratos.

Um dos primeiros eventos que ocorrem após a lesão da pele é a hipóxia. $O$ comprometimento da oxigenação tecidual, devido ao rompimento da vasculatura, limita o processo de cicatrização, uma vez que baixas concentrações de $\mathrm{H}_{2} \mathrm{O}_{2}$ melhoram o reparo tecidual (ROY et al., 2006). As espécies reativas de oxigênio (EROs) são importantes não somente para esterilizar o local da ferida como também atuam como sinalizadores celulares e assim regulam a ativação de fatores de transcrição, (MORGAN e LIU, 2010), a resposta migratória de células inflamatórias (TOBAR et al., 2008) e a produção de citocinas. O aumento no conteúdo de $\mathrm{H}_{2} \mathrm{O}_{2}$ uma hora após o ferimento, observado no grupo $\mathrm{Li}$, pode estar relacionado com a maior migração de células inflamatórias ao local da ferida (NAKAMURA et al., 2003).

O movimento direcionado de células através de gradientes extracelulares (quimiotaxia) é uma resposta fundamental durante o processo inflamatório 
(JANETOPOULOS e FIRTEL, 2008). Este movimento celular é essencial para o remodelamento e posterior homeostasia de tecidos durante a cicatrização de feridas (MARTIN e PARKHURST, 2004). O recrutamento de leucócitos do sangue para locais inflamados é modulado por diversos fatores: expressão de moléculas de adesão, interação entre os vasos e os leucócitos e a presença de quimiocinas (LEY et al., 2007).

As moléculas de adesão que participam do recrutamento de leucócitos são as selectinas e as integrinas. As selectinas são expressas na superfície de leucócitos (L-selectina) e de células endoteliais (P e E-selectina) quando ativadas e são fundamentais no início da resposta migratória. As interações das selectinas com seus receptores promovem a aderência e a dissociação rápida facilita o rolamento. Assim, as selectinas participam da primeira etapa da adesão dos leucócitos (PRICE e LOSCALZO, 1999). A interação entre as selectinas e seus ligantes reduz a velocidade de rolamento (rolling) dos leucócitos sobre os vasos aumentando a chance de ativação dessas células por agentes quimioatraentes como a interleucinas-8 (IL-8) (PETRI et al., 2008). Com a redução na velocidade, ocorre também maior probabilidade de interação entre as integrinas e conseqüente adesão dos leucócitos ao endotélio. As $\beta 2$-integrinas são armazenadas no interior das vesículas intracelulares e transportadas à membrana plasmática durante a ativação dos neutrófilos (SENGELOV et al., 1993). Elas interagem com as moléculas de adesão intercelular (ICAMs) expressas no endotélio e assim permitem a firme adesão do leucócito ao vaso.

As quimiocinas direcionam o recrutamento de leucócitos da corrente sanguínea para os tecidos extravasculares através da interação com os receptores expressos na superfície dos leucócitos (BARSANTE et al., 2008). Em ratos, uma importante família de quimiocinas para neutrófilos é a CINC (citocinas indutoras de quimiotaxia de neutrófilos) (SHIBATA et al., 1995). Um dos componentes dessa família é a CINC-2 (também conhecida como CXCL3). Neutrófilos são tanto fonte quanto alvo principal dessa quimiocina, cuja importância no recrutamento de neutrófilos já foi demonstrado em diferentes modelos de inflamação (SHIBATA et al., 1995; ULICH et al., 1995; SHANLEY et al., 1997). 
A interação quimiocina/receptor, em neutrófilos, desencadeia uma série de eventos citoplasmáticos que resultam na modificação do citoesqueleto com acúmulo de actina em uma das extremidades da célula (GLOGAUER et al., 2000).

Os efeitos dos ácidos graxos (OL e $\mathrm{Li}$ ) sobre o recrutamento de leucócitos para locais inflamados ainda são controversos. Leite et al. (2005) observaram redução na migração de neutrófilos, na presença de LPS, em camundongos alimentados com óleo de oliva, mas não houve diferença entre o grupo que recebeu óleo de soja e os animais controle. $O$ efeito do óleo de oliva foi associado à redução na produção de leucotrieno $\mathrm{B}_{4}\left(\mathrm{LTB}_{4}\right)$, um potente agente quimioatraente para neutrófilos (RIOS-SANTOS et al., 2003). A adesão de monócitos a células endoteliais também foi reduzida após a ingestão de dieta rica em ácido oleico (MATA et al., 1996; TSIMIKAS et al., 1999). A ingestão de óleo de oliva reduziu a expressão de ICAM-1 e LFA-1 em linfócitos (SANDERSON et al., 1995). Entretanto, Tsuzuki et al. (1997) relataram aumento na migração de linfócitos em decorrência da maior expressão de $\alpha-4$ integrina e L-selectina em animais alimentados com óleo de oliva. O ácido oleico modificou o citoesqueleto dos leucócitos e induziu a fusão de vesículas com a membrana celular liberando assim $\beta_{2}$-integrina in vitro (MASTRANGELO et al., 1998). A administração de OL, apesar de não ter alterado o recrutamento de células inflamatórias na ferida, aumentou a migração de neutrófilos, como observado no peritônio e no ensaio da bolsa de ar (Figuras 13 e 16).

No presente estudo, animais suplementados com Li apresentaram aumento na migração de células inflamatórias uma hora após a indução da ferida (Figura 9). Este efeito sobre o recrutamento de leucócitos foi confirmado nos ensaios de bolsa de ar e na migração induzida para o peritônio (Figuras 13 e 16). A menor velocidade no rolamento dos neutrófilos permite que estes reconheçam moléculas quimiotáticas e inicie o processo de migração mediado por receptores (HUO et al., 2000; SALAS et al., 2004; CHESNUTT et al., 2006). Como demonstrado, a administração de Li induziu aumento na interação leucócitos-endotélio (Figura 15), facilitando a migração transendotelial para a ferida.

A administração de Li elevou as concentrações de CINC-2aß, na ferida, no sobrenadante da cultura de neutrófilos como também no exsudato inflamatório. Esta 
quimiocina influencia a liberação de grânulos dos neutrófilos (WALZ et al., 1987), estimula a aderência dos neutrófilos às células endoteliais, através do CD11b/CD18 (CARVETH et al., 1989), aumenta a expressão das moléculas de adesão (DETMERS et al., 1990) e induz o burst respiratório (WALZ et al., 1987). Conseqüentemente, o aumento na produção de CINC-2 $\alpha \beta$ pode acelerar a resposta inflamatória, com aumento do influxo e a ativação de neutrófilos localmente.

Tendo em vista os efeitos da administração dos ácidos graxos OL e Li sobre a produção de EROs, a migração de leucócitos e a produção de CINC-2 $\alpha \beta$ e considerando que todos esses processos são controlados por fatores de transcrição, investigamos se a ativação do NF-KB e o AP-1 está relacionada com as alterações observadas. Segundo Yates e Rayner (2002), há poucos estudos sobre a relação entre a ativação de fatores de transcrição e o processo de reparo tecidual. Desta forma, nosso estudo permite esclarecer uma parte importante da regulação da cicatrização.

Como mencionado anteriormente, o NF-kB é encontrado no citoplasma na forma inativa (forma incapaz de se ligar ao DNA), associado à proteína inibitória $\mathrm{KB}$ (IKB), a qual impede a translocação do fator de transcrição para o núcleo. Após a estimulação das células com ativadores desse fator de transcrição, por exemplo LPS e TNF- $\alpha$, ocorre ativação da enzima I-KB quinase (IKK), que fosforila a proteína IKB. Após a fosforilação, a IKB é ubiquitinada e degradada pelo proteassoma 26S. O dímero NF-kB transloca-se para o núcleo e ativa genes-alvo após sua interação com os elementos responsivos do gene (BALDWIN, 1996). Dentre os alvos do NF-KB está o gene da proteína IKB, que sofre um aumento de transcrição. A proteína IKB interage com o fator de transcrição, promovendo o seu retorno ao citoplasma e inativação, atuando na terminação da resposta transcripicional do NF-KB (ARENZANA-SEISDEDOS et al., 1995).

Os ácidos graxos $\omega-3$ (EPA e DHA) inibem a ativação do NF-kB por impedir a fosforilação do I-KB e assim prevenir a translocação do NF- KB para o núcleo (NOVAK et al., 2003; ZHAO et al., 2004). Por outro lado, Rusyn et al. (1999) demonstraram que a suplementação com óleo de milho (rico em ácido linoleico) induz ativação do NF-kB em células Kupffer de ratas. O efeito do óleo de milho foi tempo e dose-dependente, atingindo a ativação máxima em 8 horas e em 36 horas 
já havia alcançado os valores basais. Uma vez que o uso de inibidor da NADPH oxidase (DPI) reverteu a ativação do NF-kB, os autores concluíram que os oxidantes gerados nas células Kupffer estão envolvidos na ativação do fator de transcrição (RUSYN et al., 1999). No presente estudo, a resposta do NF-kB a administração de OL foi tempo-dependente, sendo ativado no início do processo inflamatório e inibido na resolução da inflamação. Este efeito foi acompanhado de alterações nas concentrações de citocinas inflamatórias no local. Diferentemente do que foi observado por Rusyn et al. (1999), a administração de Li não modificou a ativação do NF-kB em uma hora, mas inibiu esse fator de transcrição 24 horas após a indução da ferida. Apesar de não ter influenciado a ativação do NF-kB na primeira hora da ferida, a administração de Li ativou o AP-1 uma hora após a indução da ferida e, esta ativação permaneceu após 24 horas. A expressão das subunidades do AP-1 é influenciada por diversas citocinas como as interleucinas, via ativação da via das MAP quinases (ANGEL et al., 2001).

Após um trauma físico, as citocinas são produzidas/liberadas no local lesionado e só ocorre elevação sistêmica após algumas horas do dano. Muito se sabe sobre a importância das citocinas em geral, mas poucos autores avaliaram a importância dessas para a homeostasia da pele (GRELLNER et al., 2000). Citocinas atuam em concentrações baixas e, direta ou indiretamente, modulam o processo de cicatrização por estimularem a quimiotaxia de neutrófilos, macrófagos e fibroblastos, crescimento de fibroblastos e queratinócitos, a reorganização da matriz extracelular, entre outras ações (HUBNER et al., 1996). IL-1 e TNF- $\alpha$ são importantes mediadores inflamatórios (THONSOM, 1998). Tanto a epiderme como o estrato córneo contem grande quantidade de IL-1 $\beta$ (HAUSER et al., 1986), levando ao conceito de que a pele é um reservatório desta citocina, aguardando ser liberada após alguma injuria (MURPHY et al., 2000). Embora não completamente esclarecido, sabe-se que a IL-1 induz a transcrição de diversos genes como moléculas de adesão, quimiocinas, citocinas e cicloxigenases importantes para a instalação e resolução da resposta inflamatória. Esta citocina ativa o fator de transcrição NF-KB e assim aumenta a expressão de genes inflamatórios.

Hubner et al. (1996) demonstraram que a expressão de IL-1ß RNAm pode ser detectada 7 horas após a injúria e que, entre 15-24 horas após a indução da ferida, 
essa atinge seu conteúdo máximo. No mesmo trabalho, foi observado que 5 dias (120 horas) após a indução da ferida a expressão de todas as citocinas já está em declínio e que voltam aos valores iniciais no $13^{\circ} \mathrm{dia}$. Nossos resultados corroboram com estes achados. Entretanto, detectamos CINC-2 $\alpha \beta$, IL-1 $1 \beta$ e TNF- $\alpha$ uma hora após a ferida e verificamos que o pico de produção dessas ocorre 24 horas após a injúria no grupo controle. Este comportamento mostra a importância da regulação na produção dessas citocinas para a cicatrização. De acordo com Hubner et al. (1996), os neutrófilos são responsáveis pela liberação das citocinas nas primeiras horas após o ferimento. Considerando que a liberação de IL-1 $\beta$ e TNF- $\alpha$ precede a produção de fatores de crescimento (BROWN et al., 1992), a liberação rápida dessas citocinas pode acelerar o reparo tecidual. A suplementação com os ácidos $\mathrm{OL}$ e Li antecipou a liberação de TNF- $\alpha$ e CINC-2a $\beta$, respectivamente, sugerindo que esses ácidos graxos podem precipitar a produção de outras citocinas próinflamatórias. CINC-2aß (também referida como IL-8) é um potente agente quimioatraente para neutrófilos. $O$ bloqueio dos receptores desta quimiocina inibe 0 influxo dos neutrófilos à área inflamada (GERARD e ROLLINS, 2001; KASAMA et al., 2005; BIZZARRI et al., 2006; WELLS et al., 2006).

Com base nos resultados apresentados, sugerimos que a suplementação com OL e Li modula o processo de cicatrização, acelerando a resposta inflamatória e ativando fatores de transcrição, que desempenham função importante na regulação de genes essenciais para o reparo tecidual. Acreditamos que os neutrófilos respondem por grande parte desses efeitos, considerando a infiltração de neutrófilos nas primeiras horas após a injúria, como mostrado nas análises histológicas. Desta forma, avaliamos os efeitos da ingestão OL e Li sobre funções de neutrófilos.

Os efeitos citotóxicos do OL e Li têm sido extensivamente demonstrados em estudos in vitro (CURY-BOAVENTURA et al., 2005; CURY-BOAVENTURA et al., 2006). Entretanto, não existem estudos mostrando os efeitos da ingestão de ambos os ácidos graxos na morte celular. Considerando que não houve diferença significativa na viabilidade celular e na fragmentação de DNA entre os grupos controle e tratado, os efeitos apresentados não são decorrentes de indução da morte de neutrófilos. 
A expressão de L-selectina e o rolamento de leucócitos nos vasos foram elevados após a ingestão de OL ou Li. Por outro lado, o número de células aderidas só aumentou no grupo suplementado com OL (Figura 15). No modelo de bolsa de ar, observamos que ambos os ácidos graxos elevaram a migração e a produção de CINC-2aß. Com base nesses resultados sugerimos que o aumento na resposta migratória de neutrófilos, exercido pela ingestão de OL ou Li envolve a modulação da expressão das moléculas de adesão e de agentes quimioatraentes como CINC$2 \alpha \beta$.

Os neutrófilos produzem diversas citocinas cuja ação principal é recrutar leucócitos para o foco inflamatório (quimiocinas) como IL-8, MIP (proteína inflamatória de macrófagos) que atraem principalmente neutrófilos (SCAPINI et al., 2000). Além disso, essas células também constituem fonte importante de citocinas pró-inflamatórias como TNF- $\alpha$ (fator de necrose tumoral) e IL-1 $\beta$ e anti-inflamatórias como IL-1 ra, TGF- $\beta$ (fator de crescimento tumoral- $\beta$ ) e IL-10 (interleucina 10) (CASSATELLA, 1995).

Baer et al. (2004) não observaram diferenças significativas nas concentrações de proteína C reativa e IL-6 após a ingestão de dietas ricas em ácido oleico. Camundongos alimentados com óleo de oliva apresentaram redução na produção de MCP-1 e TNF- $\alpha$ por neutrófilos (LEITE et al., 2005). Por outro lado, a ingestão de dieta rica em ácido linoleico tem sido relacionada à elevação nas concentrações plasmáticas de IL-1ß (SADEGHI et al., 1999). Para investigar o efeito dos ácidos oleico e linoleico na produção de citocinas inflamatórias, avaliamos as concentrações de CINC-2 $\alpha \beta$ e IL-1 $\beta$ no sobrenadante de neutrófilos, em cultura de 4 e 18 horas. Ambos os ácidos graxos aceleram o processo inflamatório pois elevaram as concentrações das citocinas pró-inflamatórias em 4 horas e reduziramnas após 18 horas em cultura. A produção de citocinas é transiente e tempo dependente (THONSOM, 1998). Estas características são importantes para evitar a superprodução e os conseqüentes efeitos deletérios das citocinas sobre 0 organismo. 


\section{CONCLUSÕES}

O processo de cicatrização foi acelerado pela ingestão de ácido graxo linoleico. Com base nos resultados apresentados sugerimos que o consumo de $\mathrm{Li}$ melhora o reparo tecidual por abreviar a fase inflamatória e assim empreender a fase de formação de tecido de granulação. A ingestão de OL, por sua vez, também modulou a fase inflamatória, entretanto, as alterações observadas não foram suficientes para antecipar a próxima fase do processo de reparo tecidual. Acreditamos que os efeitos dos ácidos graxos sobre a ferida foram devidos, em grande parte, a alterações nas funções dos neutrófilos. A ingestão tanto de OL como Li elevou a resposta migratória, a expressão de moléculas de adesão, a interação leucócito-endotélio e a produção de citocinas nos neutrófilos. 


\section{REFERÊNCIAS}

AMACHER, D. E. Serum transaminase elevations as indicators of hepatic injury following the administration of drugs. Regul. Toxicol. Pharmacol., v. 27, n. 2, p. 119-130, 1998.

ANGEL, P. et al. Function and regulation of AP-1 subunits in skin physiology and pathology. Oncogene, v. 20, n. 19, p. 2413-2423, 2001.

ARENZANA-SEISDEDOS, $F$. et al. Inducible nuclear expression of newly synthesized I kappa B alpha negatively regulates DNA-binding and transcriptional activities of NF-kappa B. Mol. Cell. Biol., v. 15, n. 5, p. 2689-2696, 1995.

BAER, D. J. et al. Dietary fatty acids affect plasma markers of inflammation in healthy men fed controlled diets: a randomized crossover study. Am. J. Clin. Nutr., v. 79 , n. 6, p. 969-973, 2004.

BALDWIN, A. S. Jr. The NF-kappa B and I kappa B proteins: new discoveries and insights. Annu. Rev. Immunol., v. 14, p. 649-683, 1996.

BARSANTE, M. M. et al. Blockade of the chemokine receptor CXCR2 ameliorates adjuvant-induced arthritis in rats. Br. J. Pharmacol., v. 153, n. 5, p. 992-1002, 2008.

BEAM, J. W. Topical silver for infected wounds. J. Athl. Train., v. 44, n. 5, p. 531533, 2009.

BERLANGA-ACOSTA, J. et al. Epidermal growth factor in clinical practice - a review of its biological actions, clinical indications and safety implications. Int. Wound. J., v. 6, n. 5, p. 331-346, 2009.

BIZZARRI, C. et al. ELR+ CXC chemokines and their receptors (CXC chemokine receptor 1 and CXC chemokine receptor 2) as new therapeutic targets. Pharmacol. Ther., v. 112, n. 1, p. 139-149, 2006.

BRADFORD, M. M. A rapid and sensitive method for the quantitation of microgram quantities of protein utilizing the principle of protein-dye binding. Anal. Biochem., v. 72, p. 248-254, 1976.

BROWN, L. F. et al. Fibrinogen influx and accumulation of cross-linked fibrin in healing wounds and in tumor stroma. Am. J. Pathol., v. 130, n. 3, p. 455-465, 1988.

BROWN L. F. et al. Expression of vascular permeability factor (vascular endothelial growth factor) by epidermal keratinocytes during wound healing. J. Exp. Med., v. 176, n. 5, p. 1375-1379, 1992.

CALDER, P. C. et al. Inflammatory disease processes and interactions with nutrition. Br. J. Nutr., v. 101, p. S1-45, 2009. Suppl 1 
CARDOSO, C. R. et al. Influence of topical administration of n-3 and n-6 essential and $n-9$ nonessential fatty acids on the healing of cutaneous wounds. Wound. Repair. Regen., v. 12, n. 2, p. 235-243, 2004.

CARVETH, H. J. et al. Neutrophil activating factor (NAF) induces polymorphonuclear leukocyte adherence to endothelial cells and to subendothelial matrix proteins. Biochem. Biophys. Res. Commun., v. 162, n. 1, p. 387-393, 1989.

CASSATELLA, M. A. The production of cytokines by polymorphonuclear neutrophils. Immunol. Today., v. 16, n. 1, p. 21-26, 1995.

CHESNUTT, B. C. et al. Induction of LFA-1-dependent neutrophil rolling on ICAM-1 by engagement of E-selectin. Microcirculation, v. 13, n. 2, p. 99-109, 2006.

$\mathrm{CHO}, \mathrm{M}$. H. et al. A bioluminescent cytotoxicity assay for assessment of membrane integrity using a proteolytic biomarker. Toxicol. In Vitro, v. 22, n. 4, p. 1099-1106, 2008.

CURI R. et al. Entendendo a gordura. São Paulo: Manole, 2002.

CURY-BOAVENTURA, M. F. et al. Comparative toxicity of oleic and linoleic acid on human lymphocytes. Life Sci., v. 78, n. 13, p. 1448-1456, 2006.

CURY-BOAVENTURA, M. F. et al. Comparative toxicity of oleic acid and linoleic acid on Raji cells. Nutrition, v. 21, n. 3, p. 395-405, 2005.

DAHLEN, S. E. et al. Leukotrienes promote plasma leakage and leukocyte adhesion in postcapillary venules: in vivo effects with relevance to the acute inflammatory response. Proc. Natl. Acad. Sci. U.S.A., v. 78, n. 6, p. 3887-3891, 1981.

DE LORGERIL, M. et al. Mediterranean diet, traditional risk factors, and the rate of cardiovascular complications after myocardial infarction: final report of the Lyon Diet Heart Study. Circulation, v. 99, n. 6, p. 779-785, 1999.

DECLAIR, V. The usefulness of topical application of essential fatty acids (EFA) to prevent pressure ulcers. Ostomy Wound Manage, v. 43, n. 5, p. 48-52, 54, 1997.

DETMERS, P. A. et al. Neutrophil-activating protein $1 /$ interleukin 8 stimulates the binding activity of the leukocyte adhesion receptor CD11b/CD18 on human neutrophils. J. Exp. Med., v. 171, n. 4, p. 1155-1162, 1990.

EDWARDS, J. C. et al. The formation of a structure with the features of synovial lining by subcutaneous injection of air: an in vivo tissue culture system. J. Pathol., v. 134, n. 2, p. 147-156, 1981.

EFRON, P. A.; MOLDAWER, L. L. Cytokines and wound healing: the role of cytokine and anticytokine therapy in the repair response. J. Burn. Care. Rehabil., v. 25, n. 2, p. 149-160, 2004. 
FAINE, L. A. et al. Effects of olive oil and its minor constituents on serum lipids, oxidative stress, and energy metabolism in cardiac muscle. Can. J. Physiol. Pharmacol., v. 84, n. 2, p. 239-245, 2006.

FARSKY, S. H. et al. Chronic blockade of nitric oxide biosynthesis in rats: effect on leukocyte endothelial interaction and on leukocyte recruitment. Inflamm. Res., v. 53, n. 9, p. 442-452, 2004.

FLORIN, L. et al. Delayed wound healing and epidermal hyperproliferation in mice lacking JunB in the skin. J. Invest. Dermatol., v. 126, n. 4, p. 902-911, 2006.

FOUNDATION, B. N. Unsaturated fatty acids: nutritionam and physiological significance. London: Chapman and Hall, 1992

FUJIYAMA, Y. et al. Butter feeding enhances TNF-alpha production from macrophages and lymphocyte adherence in murine small intestinal microvessels. $\mathbf{J}$. Gastroenterol. Hepatol., v. 22, n. 11, p. 1838-1845, 2007.

GERARD, C.; ROLLINS, B. J. Chemokines and disease. Nat. Immunol., v. 2, n. 2, p. 108-115, 2001.

GILLITZER, R.; GOEBELER, M. Chemokines in cutaneous wound healing. J. Leukoc. Biol., v. 69, n. 4, p. 513-521, 2001.

GIUGLIANO, D.; ESPOSITO, K. Mediterranean diet and metabolic diseases. Curr. Opin. Lipidol., v. 19, n. 1, p. 63-68, 2008.

GLOGAUER, M. et al. Two pathways through Cdc42 couple the N-formyl receptor to actin nucleation in permeabilized human neutrophils. J. Cell. Biol., v. 150, n. 4, p. 785-796, 2000.

GRANATO, D. et al. Effects of parenteral lipid emulsions with different fatty acid composition on immune cell functions in vitro. J. Parenter. Enteral. Nutr., v. 24, n. 2, p. 113-118, 2000.

GREILING, D.; CLARK, R. A. Fibronectin provides a conduit for fibroblast transmigration from collagenous stroma into fibrin clot provisional matrix. J. Cell. Sci., v. 110 ( Pt 7), p. 861-870, 1997.

GRELLNER, W. et al. Quantitative analysis of proinflammatory cytokines (IL-1beta, IL-6, TNF-alpha) in human skin wounds. Forensic. Sci. Int., v. 113, n. 1-3, p. 251264, 2000.

GURTNER, G. C. et al. Wound repair and regeneration. Nature, v. 453, n. 7193, p. 314-321, 2008.

HAUSER, C. et al. Interleukin 1 is present in normal human epidermis. J. Immunol, v. 136, n. 9, p. 3317-3323, 1986. 
HIGUCHI, R. et al. Simultaneous amplification and detection of specific DNA sequences. Biotechnology (N Y), v. 10, n. 4, p. 413-417, 1992.

HUBNER, G. et al. Differential regulation of pro-inflammatory cytokines during wound healing in normal and glucocorticoid-treated mice. Cytokine, v. 8, n. 7, p. 548-556, 1996.

HUO, Y. et al. Role of vascular cell adhesion molecule-1 and fibronectin connecting segment-1 in monocyte rolling and adhesion on early atherosclerotic lesions. Circ. Res., v. 87, n. 2, p. 153-159, 2000.

JACKSON, S. H. et al. The p47phox mouse knock-out model of chronic granulomatous disease. J. Exp. Med., v. 182, n. 3, p. 751-758, 1995.

JANETOPOULOS, C.; FIRTEL, R. A. Directional sensing during chemotaxis. FEBS. Lett., v. 582, n. 14, p. 2075-2085, 2008.

KARIN, M. Inflammation and cancer: the long reach of Ras. Nat. Med., v. 11, n. 1, p. 20-21, 2005.

KASAMA, T. et al. Neutrophil-derived cytokines: potential therapeutic targets in inflammation. Curr. Drug Targets Inflamm. Allergy, v. 4, n. 3, p. 273-279, 2005.

KEYS, A. et al. The diet and 15-year death rate in the seven countries study. Am. J. Epidemiol., v. 124, n. 6, p. 903-915, 1986.

LEITE, M. S. et al. Mechanisms of increased survival after lipopolysaccharideinduced endotoxic shock in mice consuming olive oil-enriched diet. Shock, v. 23, n. 2, p. 173-178, 2005.

LEY, K. et al. Getting to the site of inflammation: the leukocyte adhesion cascade updated. Nat. Rev. Immunol., v. 7, n. 9, p. 678-689, 2007.

$\mathrm{LI}, \mathrm{G}$. et al. c-Jun is essential for organization of the epidermal leading edge. Dev. Cell., v. 4, n. 6, p. 865-877, 2003.

LIU, W.; SAINT, D. A. A new quantitative method of real time reverse transcription polymerase chain reaction assay based on simulation of polymerase chain reaction kinetics. Anal. Biochem., v. 302, n. 1, p. 52-59, 2002.

MARTIN, P. Wound healing--aiming for perfect skin regeneration. Science, v. 276, n. 5309, p. 75-81, 1997.

MARTIN, P.; PARKHURST, S. M. Parallels between tissue repair and embryo morphogenesis. Development, v. 131, n. 13, p. 3021-3034, 2004.

MARTINS DE LIMA, T. et al. Mechanisms by which fatty acids regulate leucocyte function. Clin. Sci. (Lond), v. 113, n. 2, p. 65-77, 2007. 
MASTRANGELO, A. M. et al. Oleic acid increases cell surface expression and activity of CD11b on human neutrophils. J. Immunol., v. 161, n. 8, p. 4268-4275, 1998.

MATA, P. et al. Effect of dietary fat saturation on LDL oxidation and monocyte adhesion to human endothelial cells in vitro. Arterioscler. Thromb. Vasc. Biol., v. 16, n. 11, p. 1347-1355, 1996.

MCCUSKER, M. M.; GRANT-KELS, J. M. Healing fats of the skin: the structural and immunologic roles of the omega- 6 and omega-3 fatty acids. Clin. Dermatol., v. 28, n. 4, p. 440-451, 2010.

MOLLINEDO, F. et al. Novel trends in neutrophil structure, function and development. Immunol. Today, v. 20, n. 12, p. 535-537, 1999.

MOORE, K. Cell biology of chronic wounds: the role of inflammation. J. Wound Care, v. 8, n. 7, p. 345-348, 1999.

MORGAN, M. J.; LIU, Z. G. Crosstalk of reactive oxygen species and NF-kappaB signaling. Cell Res., v. 21, n. 1, p. 103-115, 2011.

MOUSSA, M. et al. In vivo effects of olive oil-based lipid emulsion on lymphocyte activation in rats. Clin. Nutr., v. 19, n. 1, p. 49-54, 2000.

MURPHY, J. E. et al. Interleukin-1 and cutaneous inflammation: a crucial link between innate and acquired immunity. J. Invest. Dermatol., v. 114, n. 3, p. 602$608,2000$.

NAKAMURA, Y. et al. Arachidonic acid cascade inhibitors modulate phorbol esterinduced oxidative stress in female ICR mouse skin: differential roles of 5lipoxygenase and cyclooxygenase-2 in leukocyte infiltration and activation. Free Radic. Biol. Med., v. 35, n. 9, p. 997-1007, 2003.

NOVAK, T. E. et al. NF-kappa B inhibition by omega -3 fatty acids modulates LPSstimulated macrophage TNF-alpha transcription. Am. J. Physiol. Lung Cell Mol. Physiol., v. 284, n. 1, p. L84-89, 2003.

OTRANTO, M. et al. Effects of supplementation with different edible oils on cutaneous wound healing. Wound Repair Regen., v. 18, n. 6, p. 629-636.

PARK, N. Y. et al. Effect of dietary conjugated linoleic acid supplementation on early inflammatory responses during cutaneous wound healing. Mediators Inflamm., v. 2010, p 1-8, 2010.

PEREIRA, L. M. et al. Effect of oleic and linoleic acids on the inflammatory phase of wound healing in rats. Cell Biochem. Funct., v. 26, n. 2, p. 197-204, 2008. 
PETRI, B. et al. The physiology of leukocyte recruitment: an in vivo perspective. J. Immunol., v. 180, n. 10, p. 6439-6446, 2008.

PIEPER, B.; CALIRI, M. H. Nontraditional wound care: A review of the evidence for the use of sugar, papaya/papain, and fatty acids. J. Wound Ostomy Continence Nurs., v. 30, n. 4, p. 175-183, 2003.

PIETTE, M.; SAUGIER, J. [Effect of the intravenous infusion of a lipid emulsion on blood leukocytes in the rabbit]. Ann. Pharm. Fr., v. 28, n. 9, p. 529-534, 1970.

PRICE, D. T.; LOSCALZO, J. Cellular adhesion molecules and atherogenesis. Am. J. Med., v. 107, n. 1, p. 85-97, 1999.

RHEE, S. G. Redox signaling: hydrogen peroxide as intracellular messenger. Exp. Mol. Med., v. 31, n. 2, p. 53-59, 1999.

RIOS-SANTOS, F. et al. A critical role of leukotriene B4 in neutrophil migration to infectious focus in cecal ligaton and puncture sepsis. Shock, v. 19, n. 1, p. 61-65, 2003.

RISERUS, U. Fatty acids and insulin sensitivity. Curr. Opin. Clin. Nutr. Metab. Care, v. 11, n. 2, p. 100-105, 2008.

RODRIGUES, H. G. et al. Dietary free oleic and linoleic acid enhances neutrophil function and modulates the inflammatory response in rats. Lipids, v. 45, n. 9, p. 809819.

ROLLINS, B. J. et al. Recombinant human MCP-1/JE induces chemotaxis, calcium flux, and the respiratory burst in human monocytes. Blood, v. 78, n. 4, p. 1112-1116, 1991.

ROY, S. et al. Dermal wound healing is subject to redox control. Mol. Ther., v. 13, n. 1, p. 211-220, 2006.

RUSYN, I. et al. Corn oil rapidly activates nuclear factor-kappaB in hepatic Kupffer cells by oxidant-dependent mechanisms. Carcinogenesis, v. 20, n. 11, p. 20952100, 1999.

SADEGHI, S. et al. Dietary lipids modify the cytokine response to bacterial lipopolysaccharide in mice. Immunology, v. 96, n. 3, p. 404-410, 1999.

SALAS, A. et al. Rolling adhesion through an extended conformation of integrin alphaLbeta2 and relation to alpha I and beta I-like domain interaction. Immunity, v. 20, n. 4, p. 393-406, 2004.

SAMBROOK, J. R., D.W. . Molecular Cloning: A Laboratory Manual. New York: Cold Spring Harbor Laboratory Press, 2001.

SANDERSON, P. et al. Dietary lipid modulation of cell mediated immunity in the rat. Biochem. Soc. Trans., v. 23, n. 2, p. 273S, 1995. 
SCAPINI, P. et al. The neutrophil as a cellular source of chemokines. Immunol. Rev., v. 177, p. 195-203, 2000.

SENGELOV, $\mathrm{H}$. et al. Subcellular localization and dynamics of Mac-1 (alpha $\mathrm{m}$ beta 2) in human neutrophils. J. Clin. Invest., v. 92, n. 3, p. 1467-1476, 1993.

SHANLEY, T. P. et al. Requirement for C-X-C chemokines (macrophage inflammatory protein-2 and cytokine-induced neutrophil chemoattractant) in IgG immune complex-induced lung injury. J. Immunol., v. 158, n. 7, p. 3439-3448, 1997.

SHAULIAN, E.; KARIN, M. AP-1 in cell proliferation and survival. Oncogene, v. 20, n. 19, p. 2390-2400, 2001.

SHIBATA, F. et al. Recombinant production and biological properties of rat cytokineinduced neutrophil chemoattractants, GRO/CINC-2 alpha, CINC-2 beta and CINC-3. Eur. J. Biochem., v. 231, n. 2, p. 306-311, 1995.

SIMOPOULOS, A. P. The importance of the omega-6/omega-3 fatty acid ratio in cardiovascular disease and other chronic diseases. Exp. Biol. Med. (Maywood), v. 233, n. 6, p. 674-688, 2008.

SINGER, A. J.; CLARK, R. A. Cutaneous wound healing. N. Engl. J. Med., v. 341, n. 10, p. 738-746, 1999.

SURESH, Y.; DAS, U. N. Long-chain polyunsaturated fatty acids and chemically induced diabetes mellitus: effect of omega- 6 fatty acids. Nutrition, v. 19, n. 2, p. 93114, 2003.

THONSOM. The cytokine handbook. 3rd. ed. London, 1998.

TOBAR, N. et al. RAC1 activity and intracellular ROS modulate the migratory potential of MCF-7 cells through a NADPH oxidase and NFkappaB-dependent mechanism. Cancer Lett., v. 267, n. 1, p. 125-132, 2008.

TSANG, W. M. et al. Effect of fatty acid mixtures on phytohaemagglutinin-stimulated lymphocytes of different species. Biochem. Soc. Trans., v. 5, n. 1, p. 153-154, 1977.

TSIMIKAS, S. et al. LDL isolated from Greek subjects on a typical diet or from American subjects on an oleate-supplemented diet induces less monocyte chemotaxis and adhesion when exposed to oxidative stress. Arterioscler. Thromb. Vasc. Biol., v. 19, n. 1, p. 122-130, 1999.

TSIROGIANNI, A. K. et al. Wound healing: immunological aspects. Injury, v. 37, p. S5-S12, 2006. Suppl 1 
TSUZUKI, Y. et al. Enhanced lymphocyte interaction in postcapillary venules of Peyer's patches during fat absorption in rats. Gastroenterology, v. 112, n. 3, p. 813825, 1997.

ULICH, T. R. et al. Intratracheal administration of endotoxin and cytokines. VI. Antiserum to CINC inhibits acute inflammation. Am. J. Physiol., v. 268, n. 2, pt 1, p. L245-L250, 1995.

US DEPARTMENT OF AGRICULTURE, A. R. S. Nutrient intakes from food: mean amounts consumed per individual One Day, 2005-2006. Disponível em http://www.ars.usda.gov/ba/bhnrc/fsrg. Acesso em 15 nov 2009.

VIDGREN, H. M. et al. Incorporation of n-3 fatty acids into plasma lipid fractions, and erythrocyte membranes and platelets during dietary supplementation with fish, fish oil, and docosahexaenoic acid-rich oil among healthy young men. Lipids, v. 32, n. 7, p. 697-705, 1997.

WALZ, A. et al. Purification and amino acid sequencing of NAF, a novel neutrophilactivating factor produced by monocytes. Biochem. Biophys. Res. Commun., v. 149, n. 2, p. 755-761, 1987.

WELLS, T. N. et al. Chemokine blockers--therapeutics in the making? Trends Pharmacol. Sci., v. 27, n. 1, p. 41-47, 2006.

WOLACH, B. et al. Improved chemotactic ability of neonatal polymorphonuclear cells induced by mild membrane rigidification. J. Leukoc. Biol., v. 51, n. 4, p. 324-328, 1992.

YAQOOB, P. Monounsaturated fats and immune function. Braz. J. Med. Biol. Res., v. 31, n. 4, p. 453-465, 1998.

YAQOOB, P. et al. Effect of olive oil on immune function in middle-aged men. Am. J. Clin. Nutr., v. 67, n. 1, p. 129-135, 1998.

YATES, S.; RAYNER, T. E. Transcription factor activation in response to cutaneous injury: role of AP-1 in reepithelialization. Wound Repair Regen., v. 10, n. 1, p. 5-15, 2002.

ZHAO, G. et al. Dietary alpha-linolenic acid reduces inflammatory and lipid cardiovascular risk factors in hypercholesterolemic men and women. J. Nutr., v. 134, n. 11, p. 2991-2997, 2004.

ZHOU, M. et al. A stable nonfluorescent derivative of resorufin for the fluorometric determination of trace hydrogen peroxide: applications in detecting the activity of phagocyte NADPH oxidase and other oxidases. Anal. Biochem., v. 253, n. 2, p. 162-168, 1997. 


\section{ANEXO}

Artigo: RODRIGUES, H.G.; VINOLO, M.A.R.; MAGDALON, J.; FUJIWARA, H.; CAVALCANTI, D.M.H.; FARSKY, S.H.P.; CALDER, P.C.; HATANAKA, E.; CURI, R. Dietary free oleic and linoleic acid enhances neutrophil function and modulates the inflammatory response in rats. Lipids, n. 45, p. 809-819, 2010. 


\section{Dietary Free Oleic and Linoleic Acid Enhances Neutrophil Function and Modulates the Inflammatory Response in Rats}

Hosana Gomes Rodrigues · Marco Aurélio Ramirez Vinolo · Juliana Magdalon • Haroldo Fujiwara · Danielle M. H. Cavalcanti - Sandra H. P. Farsky ·

Philip C. Calder · Elaine Hatanaka · Rui Curi

Received: 10 February 2010/Accepted: 6 August 2010/Published online: 22 August 2010

(c) AOCS 2010

Abstract The high ingestion of oleic (OLA) and linoleic (LNA) acids by Western populations, the presence of inflammatory diseases in these populations, and the importance of neutrophils in the inflammatory process led us to investigate the effects of oral ingestion of unesterified OLA and LNA on rat neutrophil function. Pure OLA and LNA were administered by gavage over 10 days. The doses used $(0.11,0.22$ and $0.44 \mathrm{~g} / \mathrm{kg}$ of body weight) were based on the Western consumption of OLA and LNA Neither fatty acid affected food, calorie or water intake. The fatty acids were not toxic to neutrophils as evaluated by cytometry using propidium iodide (membrane integrity and DNA fragmentation). Neutrophil migration in response to intraperitoneal injection of glycogen and in the air pouch

Electronic supplementary material The online version of thi article (doi:10.1007/s11745-010-3461-9) contains supplementary material, which is available to authorized users.

H. G. Rodrigues $(\bowtie) \cdot$ M. A. R. Vinolo $~ J$. Magdalon H. Fujiwara · R. Curi

Department of Physiology and Biophysics,

Institute of Biomedical Sciences, São Paulo University, Avenida Prof. Lineu Prestes, 1524, Butantã, São Paulo,

SP 05508-900, Brazil

e-mail: hosanagr@icb.usp.br

D. M. H. Cavalcanti S. H. P. Farsky

Department of Clinical and Toxicological Analyses,

Faculty of Pharmaceutical Sciences,

São Paulo University, São Paulo, Brazil

P. C. Calder

Institute of Human Nutrition, School of Medicine,

University of Southampton, Southampton, UK

E. Hatanaka

Institute of Physical Activity and Sport Sciences,

Cruzeiro do Sul University, São Paulo, Brazil assay, was elevated after administration of either OLA or LNA. This effect was associated with enhancement of rolling and increased release of the chemokine CINC- $2 \alpha \beta$. Both fatty acids elevated L-selectin expression, whereas no effect on $\beta_{2}$-integrin expression was observed, as evaluated by flow cytometry. LNA increased the production of proinflammatory cytokines (IL- $1 \beta$ and $\mathrm{CINC}-2 \alpha \beta$ ) by neutrophils after $4 \mathrm{~h}$ in culture and both fatty acids decreased the release of the same cytokines after $18 \mathrm{~h}$. In conclusion, OLA and LNA modulate several functions of neutrophils and can influence the inflammatory process.

Keywords Neutrophil migration - Inflammation Adhesion molecules · Cytokines

Oleic acid and linoleic acid

\begin{tabular}{|c|c|}
\hline \multicolumn{2}{|c|}{ Abbreviations } \\
\hline ALT & Alanine transaminase \\
\hline AST & Aspartate transaminase \\
\hline CINC- $2 \alpha \beta$ & $\begin{array}{l}\text { Cytokine-induced neutrophil } \\
\text { chemoattractant }-2 \alpha \beta\end{array}$ \\
\hline ICAM-1 & Intercellular adhesion molecule-1 \\
\hline IL-1 & Interleukin-1 \\
\hline IL-6 & Interleukin-6 \\
\hline LDH & Lactate dehydrogenase \\
\hline $\mathrm{LTB}_{4}$ & Leukotriene B4 \\
\hline LNA & Linoleic acid \\
\hline LPS & Lipopolysaccharide \\
\hline MCP-1 & Macrophage chemoattractant protein-1 \\
\hline mRNA & Messenger RNA \\
\hline fMLP & $\mathrm{N}$-formyl-methionyl-leucyl-phenylalanine \\
\hline $\mathrm{NF}-\kappa \mathrm{B}$ & Nuclear factor kappa B \\
\hline OLA & Oleic acid \\
\hline PUFA & Polyunsaturated fatty acids \\
\hline
\end{tabular}

Q Springer AOCS * 
$\mathrm{PGE}_{2} \quad$ Prostaglandin E2

ROS Reactive oxygen species

TNF- $\alpha \quad$ Tumor necrosis factor- $\alpha$

VCAM-1 Vascular cell adhesion molecule-1

\section{Introduction}

The interest in studying the effects of fatty acids on aspects of the immune response began in 1970, when Pipette and Saugier [1] demonstrated the effects of an intravenous infusion of lipid emulsion on leukocytes isolated from rabbits. Although the effects of $\omega-3$ [2] and $\omega-6$ [3-6] polyunsaturated fatty acids have been frequently addressed in previous studies, little information is available about the action of oleic acid (OLA), the major $\omega-9$ fatty acid in the human diet, on immune function. Previous in vitro studies have shown that OLA inhibits protein kinase $\mathrm{C}$ activity in lymphocytes [7], the release of myeloperoxidase [8] and the chemotaxis of human neutrophils [9], but that it can promote necrosis and apoptosis of human lymphocytes [10]. Increased ingestion of olive oil (a major source of oleic acid) has been associated with a reduction in cardiovascular disease, rheumatoid arthritis and a variety of cancers (reviewed by Waterman et al. [11]). These effects are attributed to OLA and/or the phenols present in this oil. Since oxidative stress and inflammation are important factors involved in the etiology of these diseases and neutrophils are important cells involved in the inflammatory response, it is relevant to study the effects of OLA and other fatty acids on neutrophil functions.

Neutrophils are the first cells that migrate into tissues in response to invading bacteria or other microorganisms, and they act to destroy invading pathogens through an array of microbiocidal mechanisms [12] such as phagocytosis, and production of reactive oxygen species, cytokines and proteolytic enzymes.

Here we investigate the effects of oral administration of unesterified OLA and LNA on neutrophil responses: migration, expression of adhesion molecules, interaction with endothelium and production of proinflammatory cytokines. Changes in neutrophil responses due to fatty acids could delay or accelerate inflammation onset and/or resolution.

\section{Experimental Procedure}

Reagents

OLA, LNA, fetal bovine serum (FBS), HEPES, penicillin, streptomycin, sodium bicarbonate, lipopolysaccharide
(LPS) (Escherichia coli strain 0111:B4), $N$-formylmethionyl-leucyl-phenylalanine (fMLP), oyster glycogen and RPMI-1640 culture medium supplemented with L-glutamine were from Sigma Chemical Co. (St. Louis, MO, USA). Fluorescein isothiocyanate labeled anti rat-L-Selectin (anti-rat $\mathrm{CD} 62 \mathrm{~L}$ ) and anti rat-b2-integrin (anti-rat CD18) were purchased BD PharMingen Technical (San Diego, CA, USA).

Animals

Male Wistar rats weighing $180 \pm 20 \mathrm{~g}$ (from the Department of Physiology and Biophysics, Institute of Biomedical Sciences, São Paulo University, Brazil) were maintained at $23^{\circ} \mathrm{C}$ under a light: dark cycle of $12: 12 \mathrm{~h}$. Animals received chow (Nuvital, Curitiba, Brazil-containing $22 \%$ protein, $4.5 \%$ fat, $40.8 \%$ carbohydrate, $8 \%$ fiber, reaching $3.0 \mathrm{kcal} / \mathrm{g}$ total metabolizable energy) and water ad libitum. The fatty acid composition of the chow is presented in Table 1. Food and water consumption were evaluated after each $48 \mathrm{~h}$.

The Animal Care Committee of the Institute of Biomedical Sciences approved the experimental procedure of this study (Protocol number: 86)

Administration of Oleic and Linoleic Acids

According to the Department of Agriculture of USA [13] the average daily consumption of monounsaturated and polyunsaturated fat by adult men in the USA is 38 and $23 \mathrm{~g}$,

Table 1 Fatty acid composition of the chow

\begin{tabular}{lc}
\hline Fatty acids & $(\%)$ \\
\hline Caproic acid (6:0) & \multicolumn{1}{c}{0.37} \\
Caprylic acid (8:0) & 0.21 \\
Capric acid (10:0) & 15.35 \\
Lauric acid (12:0) & 0.05 \\
Myristic acid (14:0) & 17.06 \\
Palmitic acid (16:0) & 0.10 \\
Margaric acid (17:0) & 2.23 \\
Estearic acid (18:0) & 1.81 \\
Eicosapentaenoic acid $(20: 5 \omega-3)$ & 3.04 \\
$\alpha$-Linolenic acid (18:3 $\omega-3)$ & - \\
Docosahexaenoic acid $(22: 6 \omega-3)$ & - \\
Arachidonic acid $(20: 4 \omega-6)$ & - \\
Palmitoleic acid (16:1) & 42.59 \\
Linoleic acid (18:2 $\omega$-6) & 17.15 \\
Oleic acid (18:1 $\omega-9)$ & 100 \\
Total & 35.39 \\
Saturated fatty acids & 64.60 \\
Unsaturated fatty acids &
\end{tabular}

\section{Springer AOCS *}


respectively. This is mainly in the form of OLA and LNA, respectively [13]. Considering this information, we calculated the equivalent doses to use in rats. The diets were supplemented by the oral route (by gavage) with pure OLA or LNA at doses of $0.11,0.22$ and $0.44 \mathrm{~g} / \mathrm{kg}$ body weight, daily for 10 days. Control animals received $0.22 \mathrm{~g} / \mathrm{kg}$ body weight of water by gavage. Other studies have demonstrated that ingestion of fatty acids for short periods is able to change low density lipoprotein fatty acid composition [14], modify plasma concentrations of inflammatory markers [15] and reduce the severity of diabetes mellitus in rats [16].

\section{Nutritional Parameters}

Based on food intake and fatty acid supplementation, total caloric intake (kcal/day) was calculated as ((mean food intake $\times 3.0 \mathrm{kcal})+\mathrm{kcal}$ from fatty acid supplementation)/days of supplementation.

Biochemical Determinations

Blood samples were allowed to clot, and the sera were isolated by centrifugation at $1,000 \times \mathrm{g}$ for $10 \mathrm{~min}$ and $\mathrm{kept}$ at $-20^{\circ} \mathrm{C}$ before determination. Serum alanine transaminase (ALT), aspartate transaminase (AST), lactate dehydrogenase $(\mathrm{LDH})$ and free fatty acids were determined by routine laboratory methods using BioClin kits (Belo Horizonte, Brazil) and Wako chemicals (Neuss, Germany).

Histological Analysis

Histological evaluation of the small intestine was done by a pathologist who was blinded to the experimental groups, and it was based on the following parameters: villus:crypt ratio, epithelium, reactivity of the crypt, calciform cells number, number of intraepithelium lymphocytes, Peyer plates reactivity, muscle layer, nerve plexuses.

Neutrophil Preparation

Rat neutrophils were obtained by intraperitoneal (i.p.) lavage with $40 \mathrm{~mL}$ calcium and magnesium free PBS ( $\mathrm{pH}$ 7.4), $3 \mathrm{~h}$ after i.p. injection of $10 \mathrm{~mL} 1 \%$ (w/v) sterile glycogen solution (Sigma type II, from oyster) in PBS. The cell suspension was centrifuged at $4^{\circ} \mathrm{C}(500 \mathrm{~g}$ for $10 \mathrm{~min})$. The number of viable cells ( $>95 \%$ neutrophils) was determined in a Neubauer chamber under an optical microscope by trypan blue exclusion.

Determination of Neutrophil Fatty Acid Composition

Extraction of total lipids from neutrophils $\left(1 \times 10^{6}\right.$ cells $)$ was performed following the method of Folch et al. [17].
Fatty acid composition of neutrophils was determined by reverse phase high performance liquid chromatography (HPLC). In brief, the samples were saponified and methylated by heating for $2 \mathrm{~h}$ with $2 \mathrm{~mL}$ of $0.5 \mathrm{~mol} / \mathrm{L}$ sodium methylate. The fatty acid methyl esters formed were recovered with hexane and analyzed in a Shimadzu HPLC equipped with a fluorescence detector, using a Supelco fused silica column $(25 \mathrm{~cm} \times 4.6 \mathrm{~mm})$.

\section{Culture Conditions}

Neutrophils obtained as described above were maintained in RPMI-1640 culture medium containing 10\% FBS, glutamine $(2 \mathrm{mmol} / \mathrm{L})$, Hepes $(20 \mathrm{mmol} / \mathrm{L})$, streptomycin $(100 \mu \mathrm{g} / \mathrm{mL})$, penicillin (100 international units $/ \mathrm{mL})$ and sodium bicarbonate $(24 \mathrm{mmol} / \mathrm{L})$. Cells $\left(2.5 \times 10^{6}\right.$ cells/ $\mathrm{mL}$ ) were incubated in 24-well polystyrene culture plates at $37^{\circ} \mathrm{C}$ and $5 \% \mathrm{CO}_{2}$ with or without $5 \mu \mathrm{g} / \mathrm{mL} \mathrm{LPS} \mathrm{for} 4$ and $18 \mathrm{~h}$. This concentration of LPS is used to stimulate rat neutrophils [18]. At the end of the incubation period, cell supernatant was collected and stored at $-80^{\circ} \mathrm{C}$ until to the measurement of CINC- $2 \alpha \beta$ and IL- $1 \beta$ concentrations.

\section{Cell Membrane Integrity Assay}

Cells $\left(1 \times 10^{6}\right)$ were centrifuged at $1,000 \mathrm{rpm}$ for $5 \mathrm{~min}$ at $4^{\circ} \mathrm{C}$ and the pellet obtained was resuspended in $500 \mu \mathrm{L}$ PBS. Thereafter, $50 \mu \mathrm{L}$ propidium iodide $(50 \mathrm{mg} / \mathrm{mL}$ in PBS) were added and the cells then were analyzed by flow cytometry (FACSCalibur, Becton-Dickinson, USA). Propidium iodide is a highly water-soluble fluorescent compound that cannot pass through intact membranes and is generally excluded from viable cells. Fluorescence was measured using the FL2 channel (orange-red fluorescence$585 / 42 \mathrm{~nm}$ ). Ten thousand events were analyzed per experiment. Cells with propidium iodide fluorescence were then evaluated by using Cell Quest software (BectonDickinson).

\section{DNA Fragmentation Assay}

Cells were centrifuged as described above. The pellet obtained was resuspended in $300 \mu \mathrm{L}$ hypotonic solution containing $50 \mu \mathrm{g} / \mathrm{mL}$ propidium iodide, $0.1 \%$ sodium citrate, and $0.1 \%$ Triton-X-100. This detergent permeabilizes the cells, allowing the dye to be promptly incorporated into DNA. Cells were then incubated for $30 \mathrm{~min}$ at room temperature. DNA fragmentation was analyzed by flow cytometry after DNA staining with propidium iodide according to the method described above. Fluorescence was measured and analyzed also as described. 
Expression of Adhesion Molecules (L-Selectin and $\beta_{2}$-Integrin) Evaluated by Flow Cytometry

In order to estimate $\mathrm{L}$-selectin or $\beta_{2}$-integrin expression, leukocytes were isolated from abdominal aorta blood and collected with EDTA solution $(100 \mathrm{mg} / \mathrm{mL})$. Erythrocytes were lysed using an ammonium chloride solution $(0.13 \mathrm{M})$ and leukocytes were recovered after washing with PBS. Cells $\left(1.0 \times 10^{6}\right)$ were stimulated with $\mathrm{N}$-formyl-methionyl-leucyl-phenylalanine (fMLP; $10 \mathrm{nM}$ ) for $10 \mathrm{~min}$ for $\mathrm{L}$-selectin and $30 \mathrm{~min}$ for $\beta_{2}$-integrin measurement. After washing, leukocytes were further incubated for $30 \mathrm{~min}$ at $4^{\circ} \mathrm{C}$ in the dark with $10 \mu \mathrm{L}$ fluorescently conjugated monoclonal antibody against rat L-selectin or rat $\beta_{2}$-integrin. Immediately after incubation, cells were analyzed in a FACScalibur flow cytometer. Data from 10,000 cells were obtained and only morphologically viable neutrophils were considered for analysis. Leukocytes were separated by size and granularity through flow cytometry. As circulating leukocytes in rats are represented by lymphocytes (about $80-85 \%$ ), neutrophils (about 10-15\%), monocytes (about $4-5 \%$ ) and eosinophils (about $1 \%$ ), gates were selected as mononuclear (lymphocytes and monocytes) and polymorphonuclear (neutrophils and eosinophils) leukocytes $[19,20]$.

\section{Intravital Microscopic Assay}

Rats were anesthetized and the mesentery was exteriorized. After surgery, the animals were kept on a special board thermostatically controlled at $37^{\circ} \mathrm{C}$ that included a transparent platform on which the tissue to be transilluminated was placed. The preparation was kept moist and warmed by irrigating the tissue with a warmed Ringer-Locke solution (pH: 7.2-7.4; $\mathrm{NaCl} 154 \mathrm{mM} ; \mathrm{KCl} 5.6 \mathrm{mM} ; \mathrm{CaCl}_{2} \cdot 2 \mathrm{H}_{2} \mathrm{O}$ $2 \mathrm{mM} ; \mathrm{NaHCO}_{3} 6 \mathrm{mM}$ and glucose $5 \mathrm{mM}$ ) containing $1 \%$ gelatin. The rate of the solution outflow onto the exposed tissue was controlled to keep the preparation in continuous contact with a film of liquid. Transilluminated images were obtained by optical microscopy (Axioplan II, equipped with $\times 5.0 / 0.30$ plan-neofluar or $\times 10.0 / 0.25$ Achroplan longitudinal distance objectives/numeric aperture and $\times 1.0,1.25$ or 1.60 optovar, Carl Zeiss). The images were captured using a video camera (ZVS, 3C75DE, Carl Zeiss) and were transmitted simultaneously to a TV monitor and a computer. Images obtained in the TV monitor were recorded on video-tape. Digitized images were subsequently analyzed by using an image-analyzing software (KS 300, Kontron).

Leukocyte-Endothelial Interaction

The interaction between leukocytes and vessel walls was evaluated by determining the number of rolling and adherent leukocytes on the post capillary venule wall (20-30 $\mu \mathrm{m}$ diameter, $200 \mu \mathrm{m}$ length) of the mesentery at 10 -min intervals. Three fields were evaluated in each animal. Leukocytes moving in the peripheral of the axial stream, in contact with the endothelium, were considered to be rollers [19]. These leukocytes moved sufficiently slowly to be individually visible and were counted as they rolled past a selected point on one side of the vessel during $10 \mathrm{~min}$. The number of leukocytes adherent to the endothelium (stopped at the vessel wall) was determined in the same vascular segment during $10 \mathrm{~min}$. A positive control (fMLP) was used in this assay. After analysis of rolling and adhered cells, $10 \mu \mathrm{L}$ fMLP $\left(10^{-8} \mathrm{M}\right)$ was applied on the mesentery and after $10 \mathrm{~min}$ rolling and adherent cells were counted.

\section{Air Pouch Assay and Exudate Preparation}

Induction of rat skin air pouches was performed according to the method described by Edwards et al. [21]. Briefly, $20 \mathrm{~mL}$ of sterile air (using $0.22 \mu \mathrm{m}$ Fluoropore filters) was insufflated into the subcutaneous tissue of the back trunk of rats under anaesthesia. Seven days later, an additional $10 \mathrm{~mL}$ of sterile air was insufflated. Negative controls received $1 \mathrm{~mL}$ of sterile $\mathrm{PBS}$, and positive controls received $1 \mathrm{~mL}$ of sterile PBS plus fMLP $(10 \mathrm{nM})$ through the same route. Four hours after the injection of the stimulus, the animals were killed by decapitation and the inflammatory exudate was collected after washing the cavity with $2 \mathrm{~mL}$ of sterile PBS. The suspension was centrifuged at $500 \mathrm{~g}$ for $10 \mathrm{~min}$ at $4^{\circ} \mathrm{C}$. Cells were counted in a Neubauer chamber. The supernatant was assayed for CINC- $2 \alpha \beta$ by ELISA (DuoSet; R\&D Systems, Minneapolis, MN, USA), according to the supplier's instructions.

\section{Ex Vivo Cytokine Production}

Neutrophils $\left(2.5 \times 10^{6}\right.$ cells $)$ were incubated in the presence or absence of LPS $(5 \mu \mathrm{g} / \mathrm{mL})$ in an environment containing $5 \% \mathrm{CO}_{2}$ at $37^{\circ} \mathrm{C}$ in a humid atmosphere for 4 or $18 \mathrm{~h}$. The concentrations of CINC- $2 \alpha \beta$ and IL- $1 \beta$ in the supernatant were determined by using a commercially available enzyme-linked immunosorbent assay kit (R\&D Systems, Minneapolis, MN, USA).

\section{Statistical Analysis}

Comparisons were performed using one-way ANOVA and Dunnett's multiple comparison post test. The significance was set at $p<0.05$. Results were expressed as means \pm SEM. Pearson's correlation test was used to identify the association between the production of cytokines and the doses of the fatty acids.

\section{으 Springer $\mathrm{AOCS}$ \%}


Results

Food, calorie and water intake were not modified by administration of OLA or LNA (Table 2). Animals receiving OLA or LNA did not show any clinical sign of toxicity, such as diarrhea or hair loss. The concentrations of free fatty acids in plasma were not changed by administration of either OLA or LNA (data not shown). The highest dose $(0.44 \mathrm{~g} / \mathrm{kg}$ body weight $)$ of OLA or LNA did not induce an alteration in the activity of AST, ALT or LDH (Fig. la, b, c).

Furthermore, morphological analysis of the small intestine was performed to investigate if the route of administration, as a single bolus, and the amount of fatty acids given caused changes. There was no change in the following parameters measured: villus:crypt ratio, epithelium, reactivity of the crypt, calciform cells number, Peyer plates reactivity, muscle layer and nerve plexuses (Supplemental Fig. S1).

No alteration in membrane integrity of DNA fragmentation of neutrophils was observed in cells isolated from rats treated with OLA or LNA for 10 days compared to neutrophils isolated from control rats (water) (Fig. 2), indicating that any functional effects observed in this study do not result from increased cell death due to fatty acid administration.

Neutrophils from the OLA and LNA groups (dose $0.22 \mathrm{~g} / \mathrm{kg}$ body weight) had higher contents of oleic and linoleic acids (increase of fourfold and 14\%, respectively) (Fig. 3). No alteration was observed in the content of arachidonic acid between the groups (Fig. 3). The contents of saturated, unsaturated, and $\omega-3$ fatty acids were not affected by OLA or LNA administration (data not shown).

Neutrophil recruitment in response to injection of glycogen solution was increased in the animals that received OLA ( 0.22 and $0.44 \mathrm{~g} / \mathrm{kg}$ body weight) or LNA (all doses) (Fig. 4). Considering this result, we evaluated the expression of adhesion molecules on the surface of neutrophils. We chose the dose of $0.22 \mathrm{~g} / \mathrm{kg}$ body weight because this dose of either OLA or LNA markedly increased the recruitment of neutrophils. Both fatty acids increased L-selectin expression on the membrane surface (Fig. 5a) in
Table 2 Food intake (g/day), caloric intake (kcal/day) and water ingestion ( $\mathrm{mL} /$ day) by rats supplemented with different doses of oleic or linoleic acid during 10 days

The values are presented as means \pm SEM of ten animals per group

Fig. 1 Activities of aspartate transaminase (AST), alanine transaminase (ALT) and lactate dehydrogenase (LDH) in the serum of rats supplemented with oleic or linoleic acids (dose $0.44 \mathrm{~g} / \mathrm{kg}$ body weight). The values are presented as means \pm SEM of five animals per group

\begin{tabular}{lrrrr}
\hline Doses & \multicolumn{1}{c}{0} & \multicolumn{1}{l}{0.11} & \multicolumn{1}{l}{0.22} & \multicolumn{1}{l}{0.44} \\
\hline Oleic acid (g/kg body weight) & & & & \\
Food intake (g/day) & $23.00 \pm 0.92$ & $20.65 \pm 0.38$ & $22.19 \pm 0.85$ & $22.59 \pm 0.91$ \\
Caloric intake (kcal/day) & $69.02 \pm 2.76$ & $62.19 \pm 1.15$ & $67.04 \pm 2.56$ & $68.68 \pm 1.25$ \\
Water ingestion (mL/day) & $37.5 \pm 1.70$ & $35.5 \pm 0.84$ & $41.75 \pm 2.72$ & $40.00 \pm 1.58$ \\
Linoleic acid (g/kg body weight) & & & & \\
Food intake (g/day) & $23.00 \pm 0.92$ & $20.53 \pm 0.27$ & $20.65 \pm 1.69$ & $21.0 \pm 0.63$ \\
Caloric intake (kcal/day) & $69.02 \pm 2.76$ & $61.81 \pm 0.81$ & $62.40 \pm 5.08$ & $63.9 \pm 1.91$ \\
Water ingestion (mL/day) & $37.5 \pm 1.70$ & $36.25 \pm 0.39$ & $37.40 \pm 2.68$ & $35.25 \pm 2.03$ \\
\hline
\end{tabular}
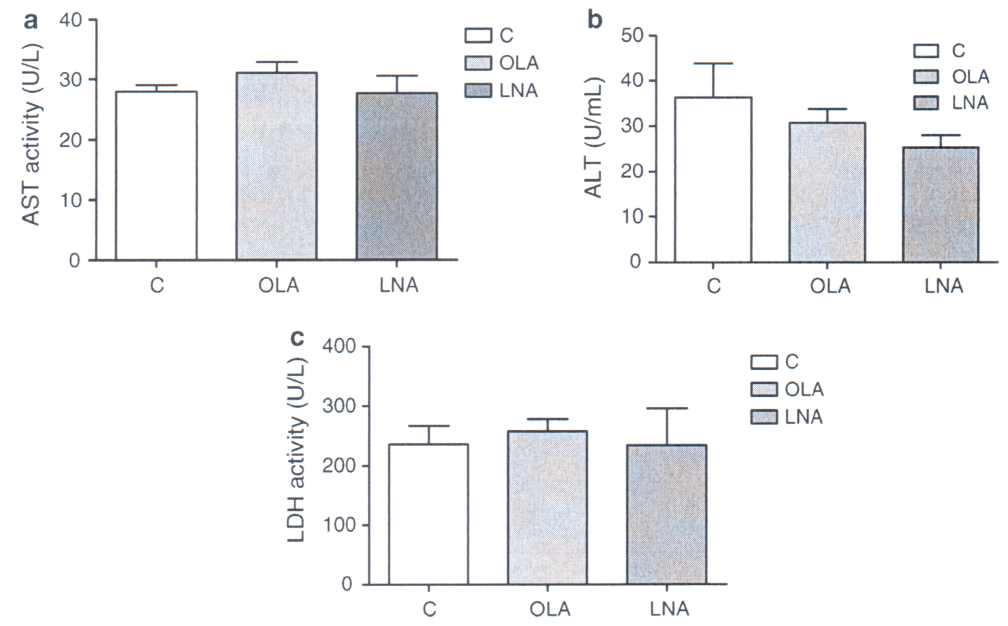

Q Springer AOCS * 
Fig. 2 Cellular viability and DNA fragmentation of

neutrophils isolated from rats supplemented with different doses of oleic or linoleic acid The values are presented as means \pm SEM of seven animals per group
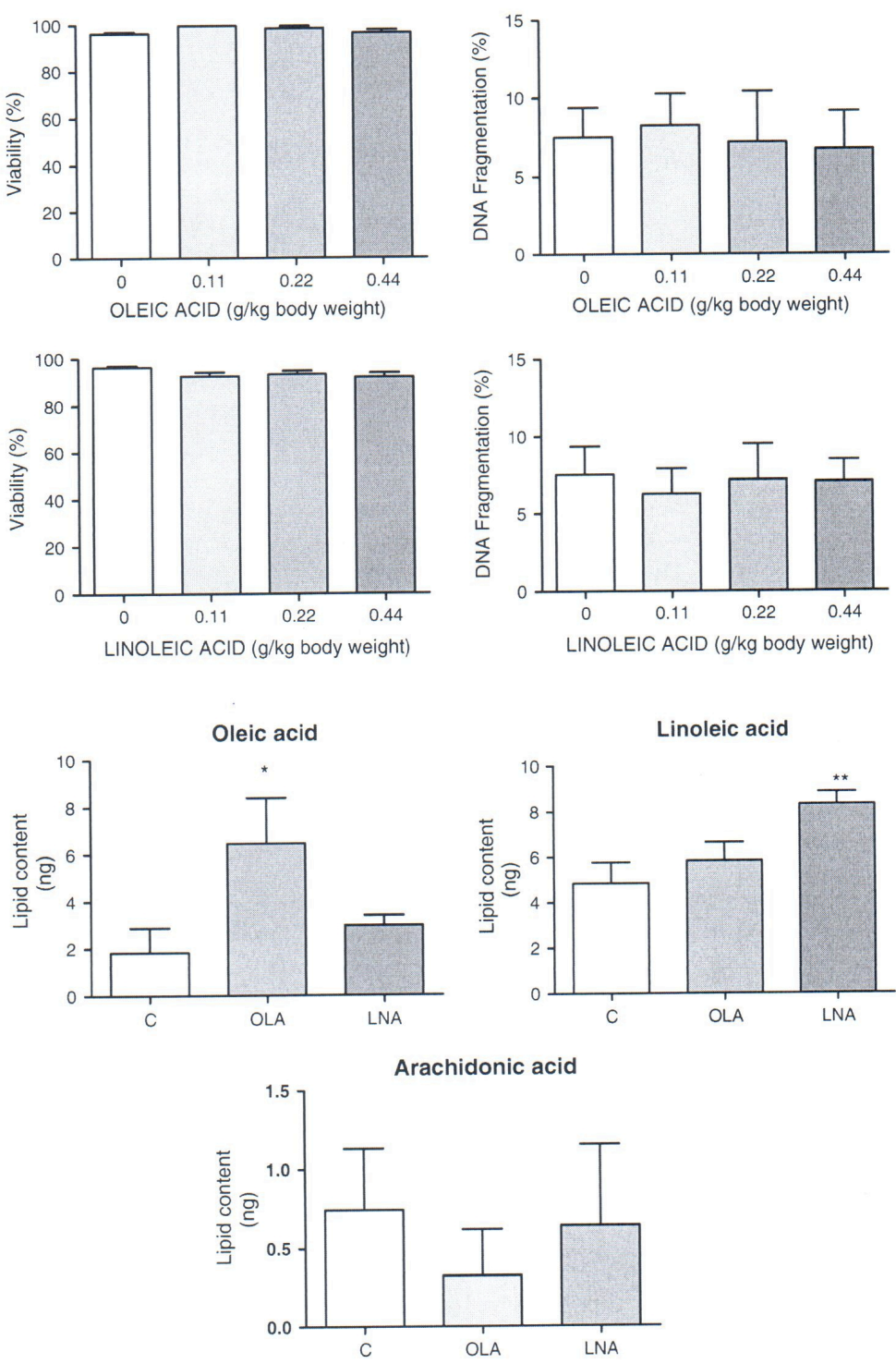

non-stimulated neutrophils, but no alteration was found for $\beta_{2}$-integrin expression (Fig. 5b). Neutrophil stimulation with fMLP increased the expression of both adhesion molecules. However, no effect of OLA or LNA was observed on the expression of adhesion molecules in fMLP stimulated neutrophils (Fig. 5a, b).
In vivo analysis, by intravital microscopy, of neutrophil interaction with the endothelium, showed that both fatty acids increase the rolling of leukocytes, but only LNA augmented the number of adherent leukocytes under basal conditions (Fig. 6a, b). After application of fMLP there was a significant increase in the number of rolling and

\section{을 Springer AOCS \%}



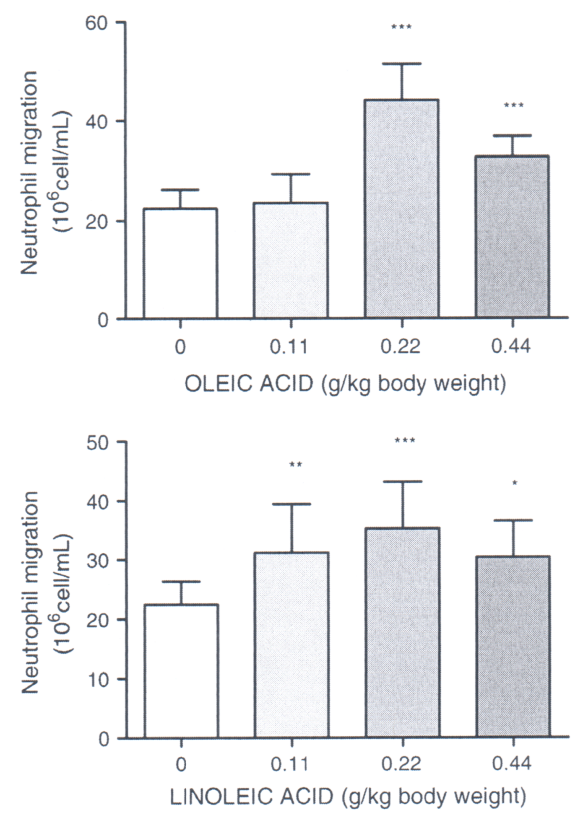

Fig. 4 Neutrophil influx into the peritoneal cavity induced by injection of glycogen solution in rats supplemented with different doses of oleic or linoleic acids. The values are presented as means \pm SEM of ten animals per group. ${ }^{*} p<0.05,{ }^{* *} p<0.01$ and $* * * p<0.001$ indicates significant difference in relation to $\mathrm{C}$ as indicated by ANOVA and Dunnett post hoc test

adherent cells. LNA increased the number of rolling and adherent leukocytes after fMLP stimulus (Fig. 6a, b).

To further investigate the effect of fatty acids on neutrophil migration, the air pouch assay was used. The migratory response of neutrophils in vivo was elevated by both fatty acids in comparison to control (without fMLP). This response was accompanied by a significant increase in the concentration of CINC- $2 \alpha \beta$, which plays an important role in neutrophil recruitment in rats (Fig. $7 \mathrm{a}$, b). In a stimulated condition (fMLP), however, no significant alteration was observed with the fatty acid treatments (Fig. 7a, b)

The influence of the ingestion of OLA or LNA on the ex vivo production of proinflammatory cytokines by neutrophils was also evaluated. The concentration of CINC- $2 \alpha \beta$ and IL- $1 \beta$ in the supernatants of neutrophils incubated for 4 and $18 \mathrm{~h}$ was determined. Despite a positive correlation between the treatment with OLA (doses $0.11,0.22$ and $0.44 \mathrm{~g} / \mathrm{kg}$ body weight) and the production of CINC- $2 \alpha \beta$ $\left(r^{2}=0.92\right.$ Pearson correlation test; $\left.p=0.02\right)$ and IL-1 $\beta$ $\left(r^{2}=0.92\right.$ Pearson correlation test; $\left.p=0.001\right)$ by neutrophils incubated for $4 \mathrm{~h}$ in the absence of LPS, no significant difference was observed compared to the control group (Fig. 8a, c). LNA increased the production of CINC$2 \alpha \beta$ and IL- $1 \beta$ by unstimulated neutrophils in a dosedependent manner $\left(r^{2}=0.93\right.$ and 0.98 , respectively; $p=0.01$ and 0.003 , respectively). This effect was statistically significant at the dose of $0.44 \mathrm{~g} / \mathrm{kg}$ body weight (Fig. 8a, d). After LPS-stimulation, OLA had no effects in the production of these cytokines, whereas, LNA $(0.44 \mathrm{~g} / \mathrm{kg}$ body weight $)$ reduced the production of CINC- $2 \alpha \beta$ (Fig. $8 \mathrm{a}, \mathrm{b}$ ).

After $18 \mathrm{~h}$ of incubation, both fatty acids significantly diminished CINC- $2 \alpha \beta$ and IL- $1 \beta$ production by neutrophils in basal condition (PBS). In LPS-stimulated neutrophils, OLA (all doses) reduced the production of IL- $1 \beta$ but did not alter production of CINC-2 $\alpha \beta$ (Fig. 9a, c).

\section{Discussion}

OLA is a major fatty acid component of meat, animal fat, milk, eggs, and some vegetable oils and is also a major fatty acid component of vegetable oils used in food manufacture [22]. LNA is a major fatty acid component of many vegetable oils, including some used in food manufacture and in animal feeds [22]. Thus, OLA and LNA are the predominant unsaturated fatty acids in the Western diet
Fig. 5 Expression of L-selectin (a) and $\beta 2$-integrin (b) in neutrophils isolated from rats supplemented with $0.22 \mathrm{~g} / \mathrm{kg}$ body weight of oleic (OLA) or linoleic (LNA) acids. The values are presented as means \pm SEM of six animals per group. ${ }^{*} p<0.05$ and

${ }^{* *} p<0.01$ indicates significant difference in relation to $\mathrm{C}$ as indicated by ANOVA and Dunnett post hoc test
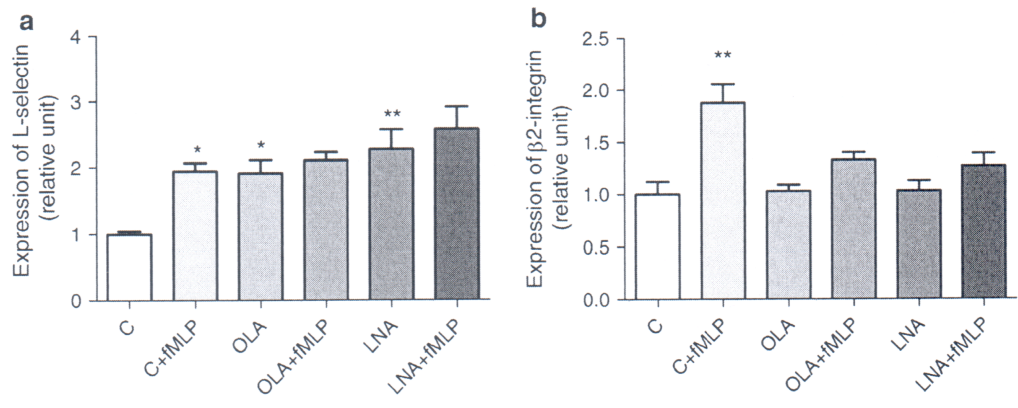


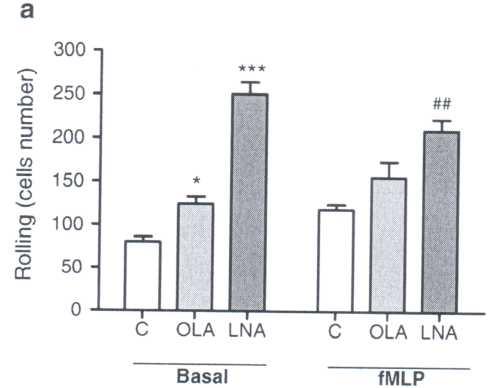

Fig. 6 Rolling (a) and adherence (b) of neutrophils isolated from rats supplemented with $0.22 \mathrm{~g} / \mathrm{kg}$ body weight of oleic (OLA) or linoleic (LNA) acids. The values are presented as mean \pm SEM of three animals per group. ${ }^{*} p<0.05$ and ${ }^{* * *} p<0.001$ indicate significant
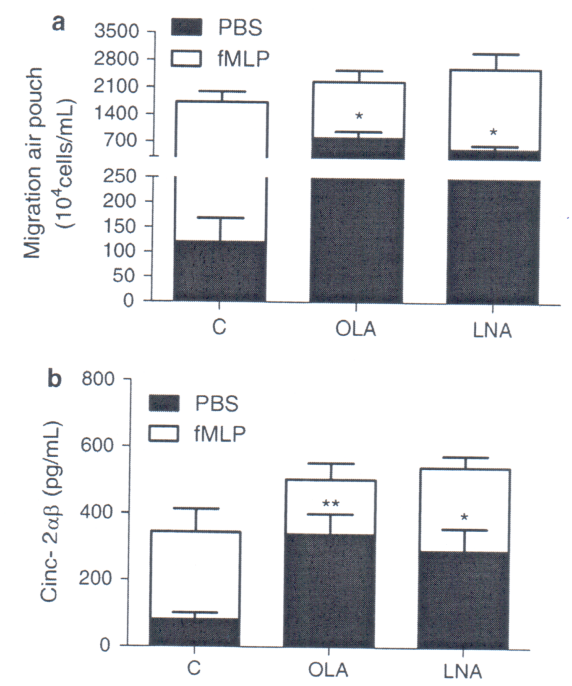

Fig. 7 Influx of neutrophils to the air-pouch (a) and CINC- $2 \alpha \beta$ (b) concentrations in the exudate of the air-pouch induced in control (C), oleic acid (OLA) and linoleic acid (LNA) groups. The dose administrated was $0.22 \mathrm{~g} / \mathrm{kg}$ body weight. The values are presented as means \pm SEM of six animals per group. ${ }^{*} p<0.05$ and ${ }^{* *} p<0.01$ indicate significant difference in relation to $\mathrm{C}$ in PBS condition

[13]. Variation in intake of these two fatty acids may influence chronic disease risk, particularly diseases with an inflammatory component.

The serum activity of AST, ALT and LDH is used as a clinical marker of liver injury [23, 24]. Damaged hepatocytes release these enzymes into the extracellular space from where they enter into the circulation, so augmenting their circulating activity. The finding that the highest dose of OLA or LNA $(0.44 \mathrm{~g} / \mathrm{kg}$ body weight $)$ did not elevate

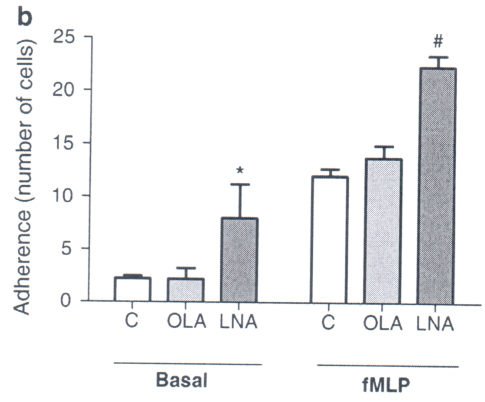

difference in relation to $\mathrm{C}$; ${ }^{\#} p<0.05$ and ${ }^{\# \#} p<0.01$ indicate significant difference in relation to $C+$ FLP as indicated by ANOVA and Dunnett post hoc test

the serum activity of these enzymes, indicates a lack of toxicity when these fatty acids are administered in the free form by gavage as was done here.

The augmentation in neutrophil migration seen is possibly due to an increase in L-selectin expression and in the production of chemoattractant CINC- $2 \alpha \beta$. LNA promoted the release of proinflammatory cytokines after a short incubation period $(4 \mathrm{~h})$ and both fatty acids inhibited this release after a prolonged incubation $(18 \mathrm{~h})$. In the presence of LPS, only LNA reduced CINC- $2 \alpha \beta$ production by neutrophils after $4 \mathrm{~h}$. However, OLA inhibited the production of IL- $1 \beta$ but did not affect CINC- $2 \alpha \beta$ release by stimulated neutrophils incubated for $18 \mathrm{~h}$. These observations reinforce the idea that OLA modifies neutrophil responses and should not be used as a control in further studies.

Fatty acids can accumulate into droplets in the cytoplasm or be incorporated into the phospholipids in cell membranes. The incorporation of fatty acids in neutrophils (either in the membrane or in droplets) is one, but not the only, possible mechanism involved in the effects seen here [25]. Since the cells continually degrade and replace their lipids [26], the difference in the incorporation of OLA and LNA into neutrophils could be due to the metabolism of LNA, keeping in mind that an inflammatory process was induced in the peritoneum and the cells were collected $3 \mathrm{~h}$ after. Another possible explanation is that each of these fatty acids exerts its effect by a different mechanism, which may not necessarily involve incorporation of the fatty acid into the cell membrane. More studies are necessary to clarify which mechanisms are involved in the effects of OLA and LNA seen in the present study.

Neutrophil recruitment requires adhesion and transmigration through blood-vessel walls, a process that involves at least four steps: rolling, activation, adhesion and transmigration. This is a highly regulated process that requires

\section{Springer AOCS *}


Fig. 8 Concentrations of CINC- $2 \alpha \beta(\mathbf{a}, \mathbf{b})$ and IL- $1 \beta$ (c, d) in the supernatant of neutrophils isolated from rats supplemented with different doses of oleic and linoleic acids and cultured during $4 \mathrm{~h}$. The values are presented as means \pm SEM of six animals per group. ${ }^{*} p<0.05$ and $* * p<0.01$ indicate significan difference in relation to $\mathrm{C}$ in PBS condition; ${ }^{*} p<0.05$ indicates significant difference in relation to $\mathrm{C}$ in stimulated (LPS) condition as indicated by ANOVA and Dunnett post hoc test
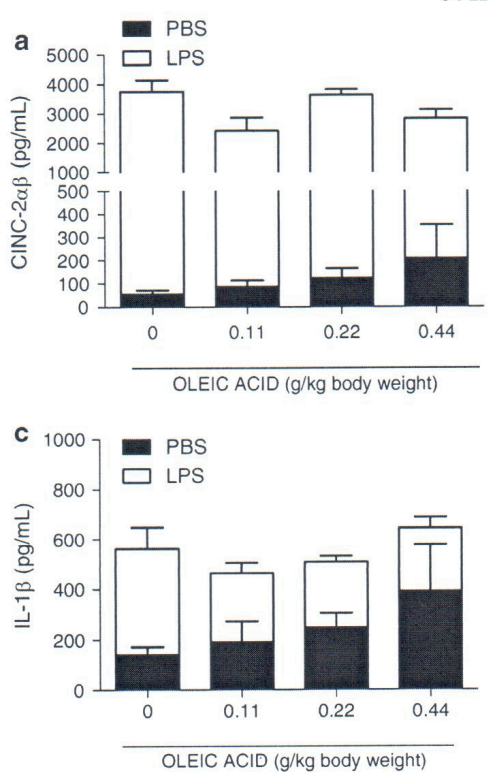

04 HOURS
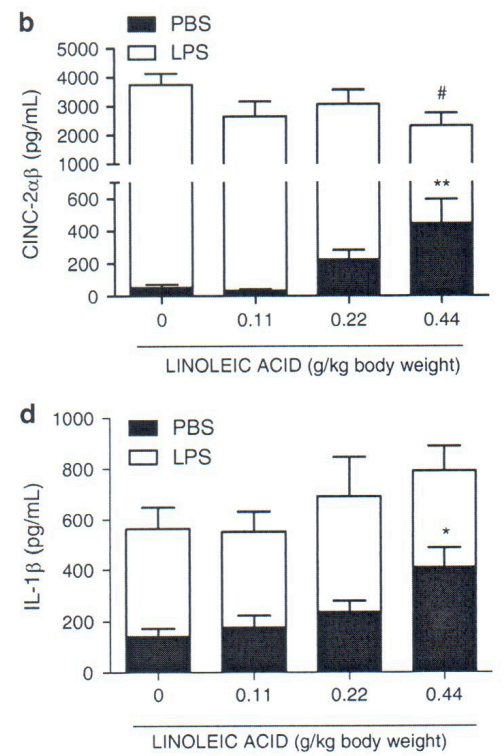

Fig. 9 Concentrations of CINC- $2 \alpha \beta(\mathbf{a}, \mathbf{b})$ and IL- $1 \beta$ (c, d) in the supernatant of neutrophils isolated from rats supplemented with different doses of oleic and linoleic acids and cultured during $18 \mathrm{~h}$. The values are presented as means + SEM of six animals per group. ${ }^{*} p<0.05$, ${ }^{* *} p<0.01$ and $* * * p<0.001$ indicate significant difference in relation to $\mathrm{C}$ in $\mathrm{PBS}$ condition; ${ }^{\# p} p<0.05,{ }^{\# \#} p<0.01$ and $p<0.05, p<0.01$ and
$\ldots \neq \#<0.001$ indicate significant difference in relation to $C$ in stimulated (LPS) condition as indicated by ANOVA and

Dunnett post hoc test

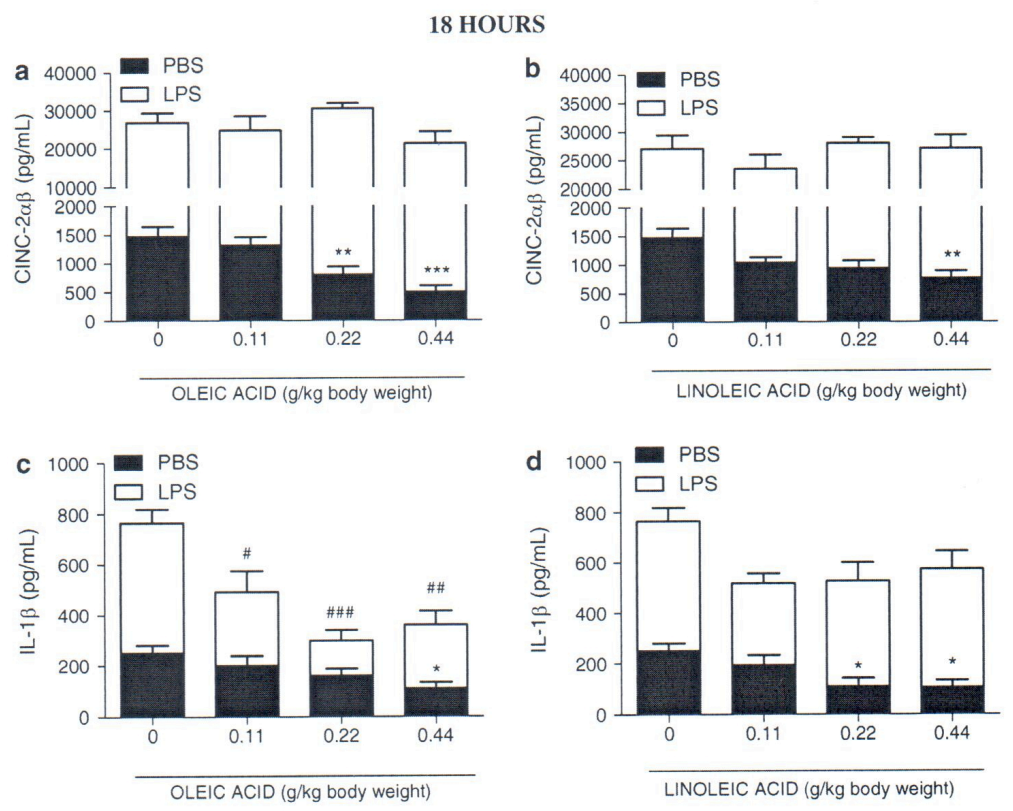

coordinated participation of cytokines (including chemokines), and endothelial and leukocyte adhesion molecules (immunoglobulins and selectins) [12]. Selectin-ligand interactions are characterized by rapid bond formation and dissociation, an interaction that mediates the first step of leukocyte adhesion, the rolling [12]. Firm attachment of 
leukocytes to the endothelium requires the interaction of integrin ligands on the leukocyte surface through immunoglobulin superfamily members, i.e., ICAM-1, ICAM-2 and VCAM-1, expressed on the endothelium [27]. Effects of OLA and LNA on endothelial cell expression of integrin ligands are conflicting: some authors demonstrated increases $[15,28]$ and others found decreases in the expression of adhesion molecules [29-31]. These contrasting results possibly occurred due to differences in the experimental conditions such as the cell type, time of incubation and fatty acid concentrations used.

In the present study the administration of either OLA or LNA augmented the rolling of neutrophils and the migration response without affecting the expression of $\beta_{2}$-integrin. Considering that the slowing of neutrophils allows these cells to recognize chemotactic molecules and to elicit a chemoattractant-receptor-mediated event [12], these results can be associated to the increase in L-selectin expression and chemokine production by neutrophils in a $\beta_{2}$-integrin independent-response. Studies with $\omega-6$ fatty acids have shown an increase in the migratory response of neutrophils through the increase in the production of prostaglandin $\mathrm{D}_{2}$ [32]. According to Tsuzuki et al. [33], olive oil increases the expression of $\alpha_{4}$-integrin and L-selectin on lymphocytes and thereby enhances the adherence of these cells. We observed an elevation in the number of adherent neutrophils after administration of LNA, but OLA had no effect. In our study, the use of pure fatty acids ensured that the effects observed are not due to minor constituents present in the parent oils or to the combination of different fatty acids as found in oils.

Another important function of neutrophils is the production of proinflammatory cytokines such as CINC-2 $\alpha \beta$ and IL-1 $\beta$. CINC- $2 \alpha \beta$ (also referred as IL-8) is a potent chemoattractant for neutrophils. Blockade of IL-8 receptors inhibits neutrophil influx to inflamed areas [34]. Augmentation in the production of CINC- $2 \alpha \beta$ hastens the inflammatory response through an increase of neutrophil influx and activation. IL- $1 \beta$ is produced by leukocytes after infection or injury. This cytokine stimulates cell metabolism and increases the expression of several genes coding for enzymes than increase the production of biologically active molecules such as arachidonic acid metabolites [35].

Previous studies investigated the effect of OLA and LNA ingestion on the production of inflammatory mediators. Baer et al. [36] did not observe significant differences in the concentration of C-reactive protein and IL- 6 after ingestion of an OLA-rich diet by humans. Mice supplemented with olive oil exhibited reduced neutrophil production of $\mathrm{PGE}_{2}, \mathrm{LTB}_{4}, \mathrm{MCP}-1$, and TNF- $\alpha$ in endotoxic shock [37]. Ingestion of a diet rich in OLA resulted in a reduction of IL-1 $1 \beta$, TNF- $\alpha$ and IL- 6 release by murine

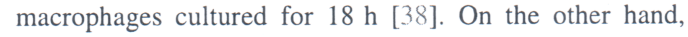

consumption of LNA by mice was correlated with an increase in plasma concentration of IL-1 $\beta$ after LPS injection [39].

The production of cytokines is transient and timedependent [40]. These characteristics are important to avoid the overproduction and, consequently, the deleterious effects of cytokines. In the present study, we observed that LNA increased the production of IL- $1 \beta$ and CINC- $2 \alpha \beta$ after $4 \mathrm{~h}$ of incubation, but at $18 \mathrm{~h}$, the concentration of these cytokines was lower than in the control group. This effect shows that LNA can accelerate the mechanisms responsible for the production/release of cytokines early in the inflammatory response, perhaps by promoting the transcription of pre-formed RNA [41]. The later decrease in production/release of cytokines could be due to the synthesis of a transcriptional repressor and/or a decrease in mRNA half-life [41]. OLA, at the same doses, did not alter the production of IL- $1 \beta$ and CINC- $2 \alpha \beta$ after a short period of incubation (i.e., $4 \mathrm{~h}$ ). However, OLA also reduced the production of these cytokines after $18 \mathrm{~h}$ of incubation in the presence (IL- $1 \beta$ ) or absence of LPS (IL- $1 \beta$ and CINC$2 \alpha \beta$ ). The difference in the concentrations of CINC- $2 \alpha \beta$ between 4 and $18 \mathrm{~h}$ is small in the OLA group. This suggests that the action of OLA is more pronounced upon the inhibition of the later process. Our results reinforce the point that LNA is more pro-inflammatory than OLA, although both alter cytokine production by neutrophils. The different responses observed between the incubation times can involve a diverse range of mechanisms [42, 43], but further studies are necessary to clarify this point.

In conclusion, we demonstrated that unesterified OLA or LNA given by gavage modify several neutrophil functions, in vivo and ex vivo, and indicate that these fatty acids may affect the course of inflammation.

Acknowledgments This research is supported by the Fundação de Amparo a Pesquisa do Estado de São Paulo (FAPESP), Coordenação de Aperfeiçoamento de Pessoal de Nível Superior (CAPES) and Conselho Nacional de Desenvolvimento Cientifico e Tecnológico. The authors acknowledge the Prof. Patricia Gama and Roberto Cabado Modia Junior for help in the histological pictures.

\section{References}

1. Pipette M, Saugier J (1970) Effect of the intravenous infusion of a lipid emulsion on blood leukocytes in the rabbit. Ann Pharm Fr 28:529-534

2. Verlengia R, Gorjao R, Kanunfre CC, Bordin S, Martins de Lima T, Martins EF, Newsholme P, Curi R (2004) Effects of EPA and DHA on proliferation, cytokines production and gene expression in Raji cells. Lipids 39:857-864

3. Barcelo-Coblijn G, Murphy EJ, Othman R, Moghadasian MH, Kashour T, Friel JK (2008) Flaxseed oil and fish-oil capsule consumption alters human red blood cell $\mathrm{n}-3$ fatty acid

\section{Springer AOCS \%}


composition: a multiple-dosing trial comparing 2 sources of $n-3$ fatty acid. Am J Clin Nutr 88:801-809

4. Chang HH, Chen CS, Lin JY (2008) Dietary perilla oil inhibits proinflammatory cytokine production in the bronchoalveola lavage fluid of ovalbumin-challenged mice. Lipids 43:499-506

5. Jeffrey NM, Sanderson P, Sherrington EJ, Newsholme EA, Calder PC (1996) The ratio of $n-6$ to $n-3$ polyunsaturated fatty acids in the rat diet alters serum lipid levels and lymphocyte functions. Lipids 31:737-745

6. Verlengia R, Gorjao R, Kanunfre CC, Bordin S, Martins de Lima T, Martins EF, Newsholme P, Curi R (2003) Genes regulated by arachidonic and oleic acids in Raji cells. Lipids 38:1157-1165

7. May CL, Southworth AJ, Calder PC (1993) Inhibition of lymphocyte protein kinase $\mathrm{C}$ by unsaturated fatty acids. Biochem and Bio Res Comm 195:823-828

8. Higazi A al-R, Bargouthi II (1994) Regulation of neutrophi activation by oleic acid. Biochim Biophys Acta 1201:442-446

9. Malawista SE, Chevance AB, van Damme J, Serhan CN (2008) Tonic inhibition of chemotaxis in human plasma. PNAS 105:17949-17954

10. Cury-Boaventura MF, Gorjão R, de Lima TM, Newsholme P, Curi R (2006) Comparative toxicity of oleic and linoleic acids on human lymphocytes. Life Sci 78:1448-1456

11. Waterman E, Lockwood B (2007) Active components and clinical applications of olive oil. Altern Med Rev 12:331-342

12. Ley K, Laudanna C, Cybulky MI, Nourshagh S (2007) Getting to the site of inflammation: the leukocyte adhesion cascade updated. Nat Rev Immunol 7:678-689

13. U.S. Department of Agriculture, A.R.S. Nutrient intakes from food: mean amounts consumed per individual, One Day, 2005-2006, 2008. http://www.ars.usda.gov/ba/bhurc/fsrg. Accessed Nov 2009

14. Cicero AFG, Nascetti F, Lopez-Sabater MC, Elosua R, Salomen JT et al (2008) Changes in LDL fatty acid composition as a response to olive oil treatment are inversely related to lipid oxidative damage: the EUROLIVE Study. J Am Coll Nutr 27:314-320

15. Pacheco YM, Lopez S, Bermudez B, Abia R, Villar J, Muriana FJG (2008) A meal rich in oleic acid beneficially modulates postprandial sICAM-1 and SVCAM-1 in normotensive and hypertensive hypertriglyceridemic subjects. J Nutr Biochem 19:200-205

16. Suresh Y, Das UN (2003) Long-chain polyunsaturated fatty acids and chemically induced diabetes mellitus: effect of $\omega-6$ fatty acids. Nutrition 19:93-114

17. Folch J, Lees M, Sloane Stanley GH (1957) A simple method for the isolation and purification of total lipides from animal tissues. J Biol Chem 226:497-509

18. Hatanaka E, Monteagudo PT, Marrocos MSM, Campa A (2006) Neutrophils and monocytes as potentially important sources of proinflammatory cytokines in diabetes. Clin Exp Immun $146: 443-447$

19. Farsky SH, Walber J, Costa-Cruz M, Cury Y, Teixeira CF (1997) Leukocyte response induced by Bothrops jararaca crude venom: in vivo and in vitro studies. Toxicon 35:185-193

20. Vinolo MA, Rodrigues HG, Hatanaka E, Hebeda CB, Farsky SH, Curi R (2009) Short chain fatty acids stimulate migration of neutrophils to inflammatory site. Clin Sci 117:331-338

21. Edwards JC, Sedgwick AD, Willoughby DA (1981) The formation of a structure with the features of synovial lining by subcutaneous injection of air: an in vivo tissue culture system. J Pathol 134:147-156

22. British Nutrition Foundation (1992) Unsaturated fatty acids: nutritional and physiological significance. Chapman and Hall, London

23. Amacher DE (1998) Serum transaminase elevations as indicator of hepatic injury following the administration of drugs. Regul Toxicol Pharmacol 27:119-130
24. Cho MH, Niles A, Huang R, Inglese J, Austin CP, Riss T, Xia M (2008) A bioluminescence toxicity assay for assessment of membrane integrity using a proteolytic biomarker. Toxicol In Vitro 22:1099-1106

25. Cabral GA (2005) Lipids as bio effectors in the immune system. Life Sciences 77:1699-1710

26. Nelson DL, Cox MM (2000) Lehninger principles of biochemistry, 3rd edn. Worth Publishers, New York

27. Sengelov H, Kjeldseng L, Diamond MS, Springer TA, Borregaard $\mathrm{N}$ (1993) Subcellular localization and dynamics of Mac-1 (alpha m beta 2) in human neutrophils. J Clin Invest 92:1467-1476

28. Perez-Martinez P, Lopez-Miranda J, Blanco-Colio L, Bellido C, Jimenez Y, Moreno JA, Delgado-Lista J, Egido J, Perez-Jimenez F (2007) The chronic intake of a Mediterranean diet enriched in virgin olive oil, decreases nuclear transcription factor kappaB activation in peripheral blood mononuclear cells from healthy men. Atherosclerosis 194:e141-e146

29. Massaro M, Carluccio MA, Paolicchi A, Bosetti F, Solaini G, De Caterina R (2002) Mechanisms for reduction of endothelial activation by oleate: inhibition of nuclear factor-kappaB through antioxidant effects. Prostaglandins Leukot Essent Fatty Acids 67:175-181

30. Couloubaly S, Delomenie C, Rousseau D, Paul JL, Grynberg A Pourci ML (2007) Fatty acid incorporation in endothelial cells and effects on endothelial nitric oxide synthase. Eur J Clin Invest 37:692-699

31. Moussa M, Le Boucher J, Garcia J, Tkaczuk J, Ragab J, Dutot G, Ohayon E, Ghisolfi J, Thouvenot JP (2000) In vivo effects of olive oil-based lipid emulsion on lymphocyte activation in rats. Clin Nutr 19:49-54

32. Tull SP, Yates CM, Maskrey BH, O'Donnell VB, Madden J, Grimble RF, Calder PC, Nash GB, Rainger G (2009) Omega-3 fatty acids and inflammation: novel interactions reveal a new step in neutrophil recruitment. PLOS Biol 7:e1000177

33. Tsuzuki Y, Miura S, Kurose I, Suematsu M, Higuchi H, Shigematsu T et al (1997) Enhanced lymphocyte interaction in postcapillary venules of Peyer's patches during fat absorption in rats. Gastroenterology 112:813-825

34. Walz A, Peveri P, Aschauer H, Baggiolini M (1987) Purification and amino acid sequencing of NAF, a novel neutrophil-activating factor produced by monocytes. Biochem Biophys Res Commun 149:755-761

35. Dinarello CA (2009) Immunological and inflammatory functions of the interleukin-1 family. Annu Rev Immunol 27:519-550

36. Baer DJ, Judd JT, Clevidence BA, Tracy RP (2004) Dietary fatty acids affect plasma markers of inflammation in healthy men fed controlled diet: a randomized crossover study. Am J Clin Nutr 79:969-973

37. Leite MS, Pacheco P, Gomes RN, Guedes AT, Castro-Faria-Neto HC, Bozza PT, Koatz VLG (2005) Mechanisms of increased survival after lipopolysaccharide-induced endotoxic shock in mice consuming olive oil-enriched diet. Shock 23:173-178

38. de la Puerta R, Marquez-Martins A, Fernandez-Arche A, RuizGutierrez V (2009) Influence of dietary fat on oxidative stress and inflammation in murine macrophages. Nutrition 25:548-554

39. Sadeghi S, Wallace FA, Calder PC (1999) Dietary lipids modify the cytokine response to bacterial lipopolysaccharide in mice Immunology 96:404-410

40. Thonsom A (1998) The cytokine handbook. 3rd edn

41. Jarrous N, Kaempfer R (1994) Induction of human interleukin-1 gene expression by retinoic acid and its regulation at processing of precursor transcripts. J Biol Chem 269:23141-23149

42. Hirasawa A, Hara T, Katsuma S, Adachi T, Tsujimoto G (2008) Free fatty acid receptors and drug discovery. Biol Pharm Bull 31:1847-1851

43. Serhan CN, Yacoubian S, Yang R (2008) Anti-inflammatory and proresolving lipid mediators. Annu Rev Pathol 3:279-312 